MAYUMI SASAKI

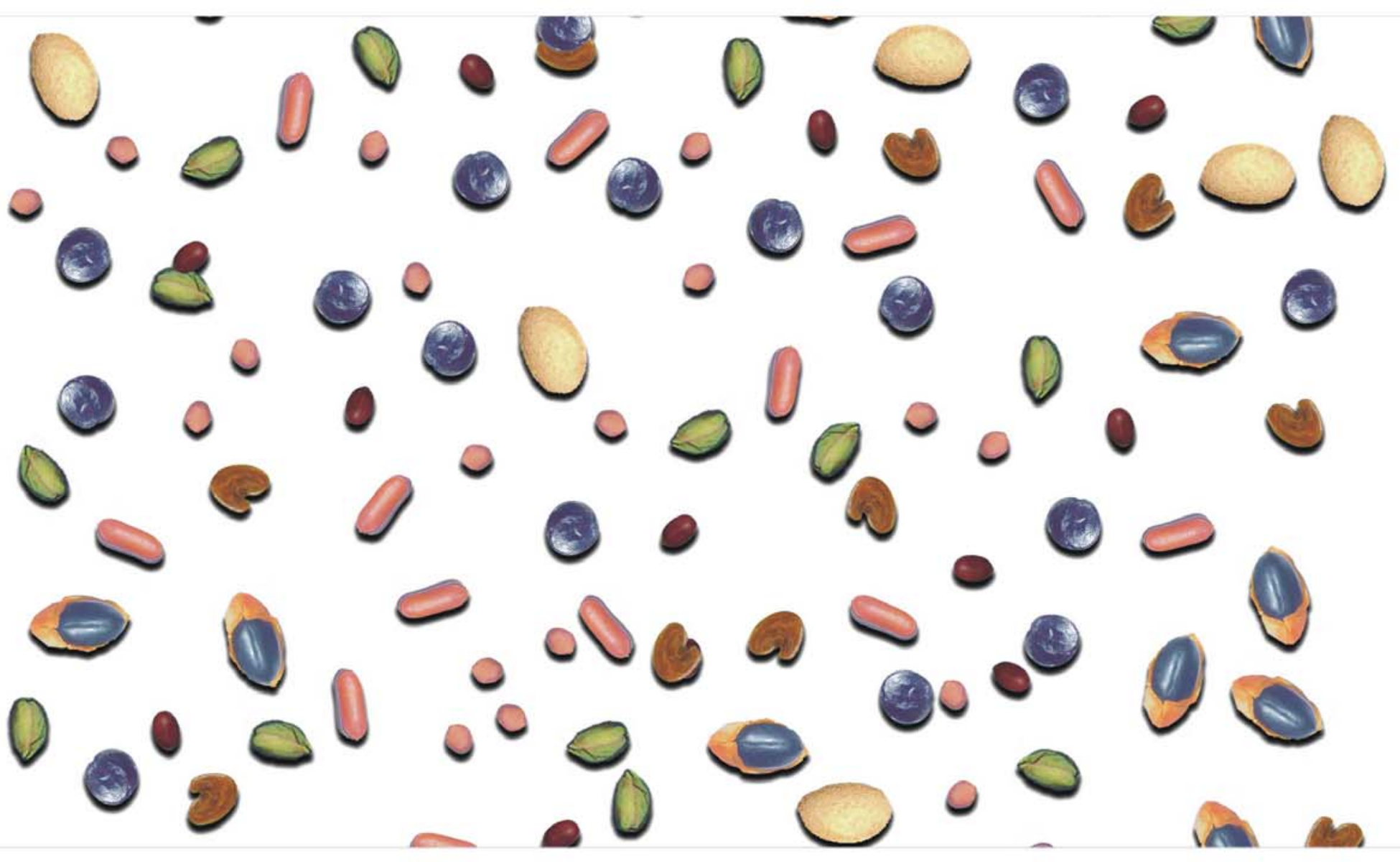

\title{
LIPÍDIOS, CARBOIDRATOS E PROTEÍNAS DE SEMENTES DE LEGUMINOSAS DO CERRADO
}

0

$0_{0}^{\theta}$

$\theta$

(2) $U-O$ 
Mayumi Sasaki

\section{Lipídios, carboidratos e proteínas de sementes}

\section{de leguminosas do cerrado}

Dissertação apresentada ao Instituto de Biociências da Universidade de São Paulo, para a obtenção de Título de Mestre em Ciências, na Área de Botânica.

Orientador: Antonio Salatino

São Paulo

2008 
Sasaki, Mayumi

Lipídios, carboidratos e proteínas de sementes de leguminosas do cerrado.

Número de páginas: vii, $75 p$.

Dissertação (Mestrado) - Instituto de Biociências da Universidade de São Paulo. Departamento de Botânica.

1. Lipídios 2. Açúcares 3. Proteínas 4. Leguminosae 5.

Cerrado. Universidade de São Paulo. Instituto de Biociências.

Departamento de Botânica.

Comissão Julgadora:

Prof(a). Dr(a).

Prof(a). Dr(a).

Prof. Dr. Antonio Salatino 
Dedico este trabalho à minha família, em especial à minha mãe (in memoriam). 


\section{AGRADECIMENTOS}

A Deus e aos meus mestres, por tudo na minha vida.

Ao Prof. Dr. Antônio Salatino pela orientação, amizade, incentivo e principalmente calma e bom humor nos momentos mais críticos da realização deste trabalho.

À Profa. Dra. Maria Luiza Faria Salatino e à Profa. Dra. Débora Y. A. C.dos Santos, pelos ensinamentos, sugestões e auxílio em diversos momentos do desenvolvimento deste projeto.

Ao Prof. Dr. Rubens Pirani e Prof. Dr. Waldir Mantovani pela identificação das espécies trabalhadas.

Ao Prof. Dr. Marcos Silveira Buckeridge, pelas sugestões, auxílio e pela autorização para a realização das dosagens de açúcares e amido.

Ao Prof. Dr. Wellington Delitti, responsável pelo Laboratório de Ciclagem de Nutrientes do Instituto de Biociências-USP, pela autorização para a realização das dosagens de nitrogênio e ao Sr. Maurício Perine, pela precisa ajuda na realização das mesmas.

Ao Ms. João Del Giudice Neto, responsável pela Reserva Biológica e Estação Experimental de Mogi-Guaçu e a todos os funcionários, em especial ao Sr. Paulo Barbosa da Silva, pelo auxílio direto nas coletas em campo, sem o qual este trabalho teria sido muito mais difícil.

À Anary pela companhia e auxílio em nossas divertidas viagens de coleta em campo.

Ao pessoal do Laboratório de Fisiologia Vegetal, em especial à Adriana, pela fundamental ajuda na análise dos açúcares, sugestões e amizade.

À Marcella, Claudinha, Vivi e Silvana pela revisão e sugestões na conclusão deste trabalho.

À Mourisa, por ser sempre tão prestativa, por sua amizade e pelas conversas tão divertidas.

Ao pessoal do Departamento de Botânica: Adne, Anary, Carol, Cassy, Célia, Cíntia, Claudinha, Confusão, Cris, Daniel, Diego, Emanuela, Fábio, Fungyi, Jorge, Júlia, Lu, Lucimar, Marina, Gina, Paulinha, Samantha, Simone, Silvana, Thiago, Vivian, Vitor, entre outros, pelo incentivo, colaboração e amizade em todos momentos.

Às "japonesas", que mesmo sem encontrar muito, estão e sempre estarão no meu coração! Obrigada por todos esses anos de amizade e pelos jantares sempre tão gostosos e animados!!!

À minha família mineira: Cida, Gabriel, Juju, Vanessa e João, por sempre me acolherem tão bem e cuidarem de mim nas minhas estadias em Campo Belo.

A todo o pessoal do Grupo Ibez, por me ajudarem a ser uma pessoa melhor, em 
especial ao Kenji, meu amigo-irmão, sempre tão prestativo.

À minha amiga-irmã Marina e sua família, por TUDO, durante todos esses anos.

À querida Fumie, sempre consertando meu físico, emocional e espiritual. Obrigada por toda a ajuda, sábios conselhos e apoio em todos os momentos.

À sempre presente, amiga de todas as horas, Marcella, por agüentar minhas inúmeras reclamações e lágrimas e por ajudar em tudo quanto foi possível, desde coletas, revisão de texto, incentivos, conselhos, estadia em Santos, pizzas, habib's, até quiches para eu não comer bisnaguinhas! Muito obrigada!!!

E, finalmente, ao Luiz, por ter entrado na minha vida, tornando-a tão mais divertida e feliz. Obrigada por sempre cuidar de mim, me agüentar, ajudar, apoiar, secar minhas lágrimas, me fazer rir, viajar comigo... Enfim, muito obrigada por tudo!!! 
Dedicatória

Agradecimentos iv

$\begin{array}{ll}\text { I. Introdução } & 01\end{array}$

$\begin{array}{ll}\text { 1. As sementes e seu potencial econômico } & 01\end{array}$

2. Constituintes das sementes 01

2.1. Carboidratos 02

2.2. Lipídios 09

2.3. Proteínas 14

2.4. Outros componentes 17

3. Leguminosas 17

4. Cerrado 24

II. Objetivos 26

$\begin{array}{ll}\text { III. Material e métodos } & 27\end{array}$

1. Coleta e identificação do material 27

2. Preparo do material botânico $\quad 27$

3. Doseamento de lipídios $\quad 29$

4. Identificação dos ácidos graxos $\quad 29$

5. Doseamento de nitrogênio total 30

6. Doseamento de carboidratos solúveis 30

7. Doseamento de amido 31

IV. Resultados e discussão 32

1. Lipídios 32

2. Carboidratos 43

3. Proteínas 45

4. Potencial econômico $\quad 47$

5. Implicações na germinação e desenvolvimento da plântula 50

V. Considerações finais 52

VI. Resumo 53

VII. Abstract 54

VIII. Referências 


\section{INTRODUÇÃO}

\section{As sementes e seu potencial econômico}

As sementes são fontes primárias para a nutrição humana e animal. No início da civilização, algumas plantas forneceram rendimento suficiente de sementes para assegurar suprimento alimentar adequado dentro de uma pequena área geográfica. Isso levou ao desenvolvimento da vida em comunidade (Bradley, 1966). Desde o início da agricultura até os dias atuais, as sementes ganharam maior importância, sendo transportadas de seus centros de origem e se espalhado pelo mundo todo, constituindo atualmente a base da alimentação humana (Heiser Junior, 1977).

As sementes possuem um papel importante em nossa civilização, pois são fontes transportáveis e compactas de carboidratos, proteínas, lipídios, vitaminas e minerais, além de serem facilmente digeridas. Além disso, são altamente calóricas, produzidas em grande quantidade e facilmente colhidas. Nas plantas perenes, a colheita de sementes não perturba as raízes nem o aparato fotossintético da planta e, diferentemente de outros órgãos vegetais, sementes maduras têm uma taxa metabólica baixa e são estáveis quando armazenadas por longos períodos. Os tecidos de armazenamento e o embrião também estão envoltos por uma dura testa que os protegem da invasão de microorganismos. Essas características, que evoluíram nas plantas com flores para aumentar a probabilidade de sobrevivência da semente, têm sido indispensáveis na manutenção da civilização humana (Bradley, 1966; Habben \& Larkins, 1995; Simpson \& Ogorzaly, 2001).

\section{Constituintes das sementes}

Os compostos de reserva das sementes podem estar presentes no eixo embrionário ou mais raramente no perisperma, ou em uma combinação dessas partes das sementes. Porém, o endosperma e os cotilédones são os principais órgãos com função de reserva (Mayer \& Poljakoff-Mayber, 1975; Boesewinkel \& Bouman, 1995). Embora alguns endospermas sejam principalmente reservas de 
lipídios e proteínas (mamona, por exemplo), a maioria das espécies parece ter se especializado em armazenar carboidratos. O amido é encontrado, em geral, nos endospermas de cereais e galactomananos nas leguminosas. Por outro lado, os cotilédones possuem uma variedade relativamente maior de compostos de reserva, armazenando carboidratos (amido e polissacarídeos de reserva de parede celular), juntamente com grandes proporções de lipídios e proteínas (Buckeridge \& Reid, 1996).

Os constituintes das sementes são determinados geneticamente, mas a quantidade relativa destes constituintes às vezes é dependente de fatores ambientais, tais como nutrição mineral e clima. Iwanoff (1927 apud Mayer \& Poljakoff-Mayber, 1975) mostrou que o conteúdo de proteínas do trigo variava comparando-se várias regiões da Rússia, enquanto o de ervilha era constante. $\mathrm{O}$ moderno cultivo de plantas permitiu a seleção de acordo com diferenças quantitativas dos constituintes de sementes. Assim, a soja tem sido melhorada objetivando maior quantidade de proteína, o linho, quantidade de óleo e o trigo, quantidade de proteína e amido. Além de proteínas, lipídios e carboidratos, as sementes contêm outros compostos em menor quantidade, mas que não deixam de ser importantes, como minerais, taninos, alcalóides, lectinas, inibidores de proteinase e oligossacarídeos da família da rafinose. Desses, muitos são notoriamente conhecidos por serem indesejáveis nutricionalmente ou até mesmo tóxicos (Bewley \& Black, 1994).

\subsection{Carboidratos}

Carboidratos abrangem um dos maiores grupos de compostos orgânicos encontrados na natureza e juntamente com as proteínas formam os constituintes principais do organismo vivo, além de serem a mais abundante e econômica fonte de energia para o homem (Bobbio \& Bobbio, 2003). Açúcares, carboidratos ou sacarídeos podem ser definidos quimicamente como poliidroxialdeídos ou poliidroxicetonas e seus derivados. Isso significa que possuem vários grupamentos hidroxila e também um grupamento aldeído ou cetona em suas moléculas (Dietrich et al., 1988).

Nas plantas, os carboidratos são encontrados como constituintes estruturais 
(celulose e outros polissacarídeos de parede); reserva de energia, na forma de polímeros (como o amido); constituintes de vários metabólitos (como ácidos nucléicos e coenzimas) e numerosos glicosídeos; e como precursores requeridos para a síntese de outros metabólitos (formados a partir de dióxido de carbono e água), sendo o ponto de partida para a formação de todos os componentes orgânicos na natureza (Bruneton, 1999).

Os carboidratos podem ser classificados em três grupos principais: monossacarídeos, oligossacarídeos e polissacarídeos.

Monossacarídeos são compostos que não podem ser hidrolisados a compostos mais simples. São classificados em aldoses (possuem grupamentos do tipo aldeído), como a glucose; e em cetoses (possuem grupamentos do tipo cetona), como a frutose (Bobbio \& Bobbio, 2003). A glucose e, em menor grau a frutose, são relativamente abundantes nos estágios iniciais do desenvolvimento da semente. Entretanto, na forma livre esses monossacarídeos perfazem uma pequena proporção do total de açúcares em sementes maduras: menos de 0,2\% do peso seco de cereais e $0,03 \%$ do peso seco de cotilédones de soja (Kuo et al. 1997).

Oligossacarídeos são polímeros compostos de 2 a 10 unidades de resíduos de monossacarídeos unidos por ligações glicosídicas, como a sacarose (dissacarídeo formado por uma molécula de glucose e uma de frutose), que é o oligossacarídeo mais importante, tanto pela quantidade e freqüência com que é encontrado na natureza, como pela sua importância na alimentação humana (Bobbio \& Bobbio, 2003). As sementes de leguminosas têm entre 0,3-2,9\% do peso da semente como sacarose, mas algumas espécies apresentam em outras partes da planta teores entre 15 e 20\%, como é o caso dos colmos da cana-de-açúcar (Saccharum officinarum L., Poaceae) e das raízes da beterraba (Beta vulgaris, Amaranthaceae) (Simpson \& Ogorzaly, 2001).

Depois da sacarose, os oligossacarídeos contendo $\alpha$-D-galactose, como os açúcares da série rafinósica, são, dentre os açúcares solúveis, os mais abundantes. Nesses oligossacarídeos, um resíduo de sacarose está unido a um, dois ou três resíduos de galactose, formando a rafinose, estaquiose e verbascose, respectivamente. Em sementes de muitas leguminosas, os açúcares da série rafinósica correspondem de $5-15 \%$ do peso seco. Nos cereais, a sacarose é o açúcar predominante, mas a rafinose, estaquiose e algumas vezes a verbascose, estão presentes em quantidades significativas em grãos de Poaceae. A quebra 
desses oligossacarídeos se dá por meio da enzima a-galactosidase, mas animais superiores não produzem tal enzima, o que impossibilita a digestão dessas substâncias. Dessa forma, elas chegam à porção final do intestino e são metabolizados por bactérias anaeróbias, liberando subprodutos gasosos, os quais causam flatulência em homens e animais domésticos. Devido a esse importante fator anti-nutricional, esses oligossacarídeos vêm sendo bastante estudados (Cochrane, 2000; Heldt, 2005).

Polissacarídeos são polímeros de alto peso molecular, compostos por muitas unidades de resíduos de monossacarídeos unidos por ligações glicosídicas, de forma linear ou ramificada. Nas plantas desempenham diversas funções, destacando-se o seu papel estrutural (celulose, hemicelulose) e de reserva. Os polissacarídeos de reserva podem ser acumulados no interior do protoplasto (amido, frutanos) ou fazer parte da parede celular (galactomananos, glucanos e xiloglucanos, entre outros) (Bobbio \& Bobbio, 2003) e cada um desses compostos apresenta características que os tornam mais convenientes para a célula em determinadas situações. O amido é menos ativo osmoticamente que os frutanos e mais compactado, mas os frutanos podem ser úteis no controle do potencial osmótico da célula, enquanto os polissacarídeos de parede são quimicamente inertes e possuem diferentes níveis de solubilidade na água (Buckeridge et al., 2000b).

Os frutanos são polímeros de frutose lineares ou ramificados, muito solúveis em água quente, os quais constituem a principal reserva de carboidratos de cerca de 36 mil espécies vegetais, ocorrendo também em espécies de fungos, algas e bactérias (Figueiredo-Ribeiro et al., 1992). Os dois principais tipos são a inulina e o fleano. Inulinas são encontradas em raízes e tubérculos de Asteraceae (como dentede-leão, chicória e alcachofra-de-jerusalém), mas podem ser extraídas de algumas Liliaceae, como bulbos de lírio, cebolas, tulipas e jacintos. Já os levanos são encontrados principalmente em Poaceae (cevada, trigo) (Figueiredo-Ribeiro et al., 1992; Izydorczyk et al., 2005), única família na qual foi reportada a presença de frutanos em sementes (MacLeod \& McCorquodale, 1958). Frutanos, assim como a rafinose, não são digeridas pelo homem e devido a seu sabor doce, são usados como adoçante natural livre de calorias e na indústria de alimentos, como substitutos de gordura (Heldt, 2005). 
O amido constitui a mais importante reserva de nutrição em quase todas as plantas superiores, ocorrendo principalmente em sementes, tubérculos, rizomas e bulbos. Por ser facilmente digerido, é um dos componentes mais importantes na alimentação humana (Freitas, 2002). Nas sementes de Poaceae, o amido está presente nas células do endosperma, mas não nas células da camada de aleurona. Nas leguminosas, o amido é armazenado nos cotilédones (Cochrane, 2000). Ele é composto por unidades de glucose, constituído por uma mistura de dois homopolissacarídeos denominados amilose e amilopectina, em proporções que variam entre os amidos procedentes de diferentes espécies vegetais, ficando normalmente em torno de 1:3 e 1:4 (Amaral et al., 2007). A amilose (Figura 1A) praticamente não apresenta ramificações, sendo que as unidades de glucose são conectadas por ligações glicosídicas do tipo $\alpha(1 \rightarrow 4)$ e a porcentagem de ramificações $\alpha(1 \rightarrow 6)$ é menor do que $1 \%$ (Ball et al., 1998). A amilopectina (Figura 1B) é altamente ramificada e possui cadeias de resíduos de glucose ligados entre si por ligações glicosídicas do tipo $\alpha(1 \rightarrow 4)$, com aproximadamente $5 \%$ de ramificações $\alpha(1 \rightarrow 6)$ (Myers et al., 2000a). Ele é organizado em grânulos insolúveis em água, localizados em organelas especiais que variam em tamanho, tipo e forma conforme a espécie, órgão e estágio de desenvolvimento. A maioria das células vegetais contém amido. Alguns órgãos, como os tubérculos da batata, as raízes da batata doce e grãos de cereais acumulam-no em grandes quantidades (Sivak \& Preiss, 1995).

Os polissacarídeos de reserva de parede celular são mais restritos em sua ocorrência na natureza, porém podem chegar a representar até $40 \%$ do peso seco da semente, como os xiloglucanos em cotilédones de Hymenaea courbaril e os galactomananos em endospermas de Dimorphandra mollis. Eles são classificados de acordo com sua estrutura em mananos, que podem ser galactomananos, mananos "puros" ou glucomananos, xiloglucanos e (arabino)galactanos (Buckeridge \& Reid, 1996; Buckeridge et al., 2000a).

Os galactomananos são formados por resíduos de D-manose, unidos por ligações glicosídicas $\beta-(1 \rightarrow 4)$ para formar uma cadeia linear de manose, à qual resíduos de D-galactose são unidos por meio de ligações do tipo $\alpha-(1 \rightarrow 6)$ (Dea \& Morrison, 1975). São classificadas como gomas originárias de sementes e são comuns em endosperma de espécies de Leguminosae, mas também são encontrados em pequenas quantidades em sementes de Annonaceae, Asteraceae, 


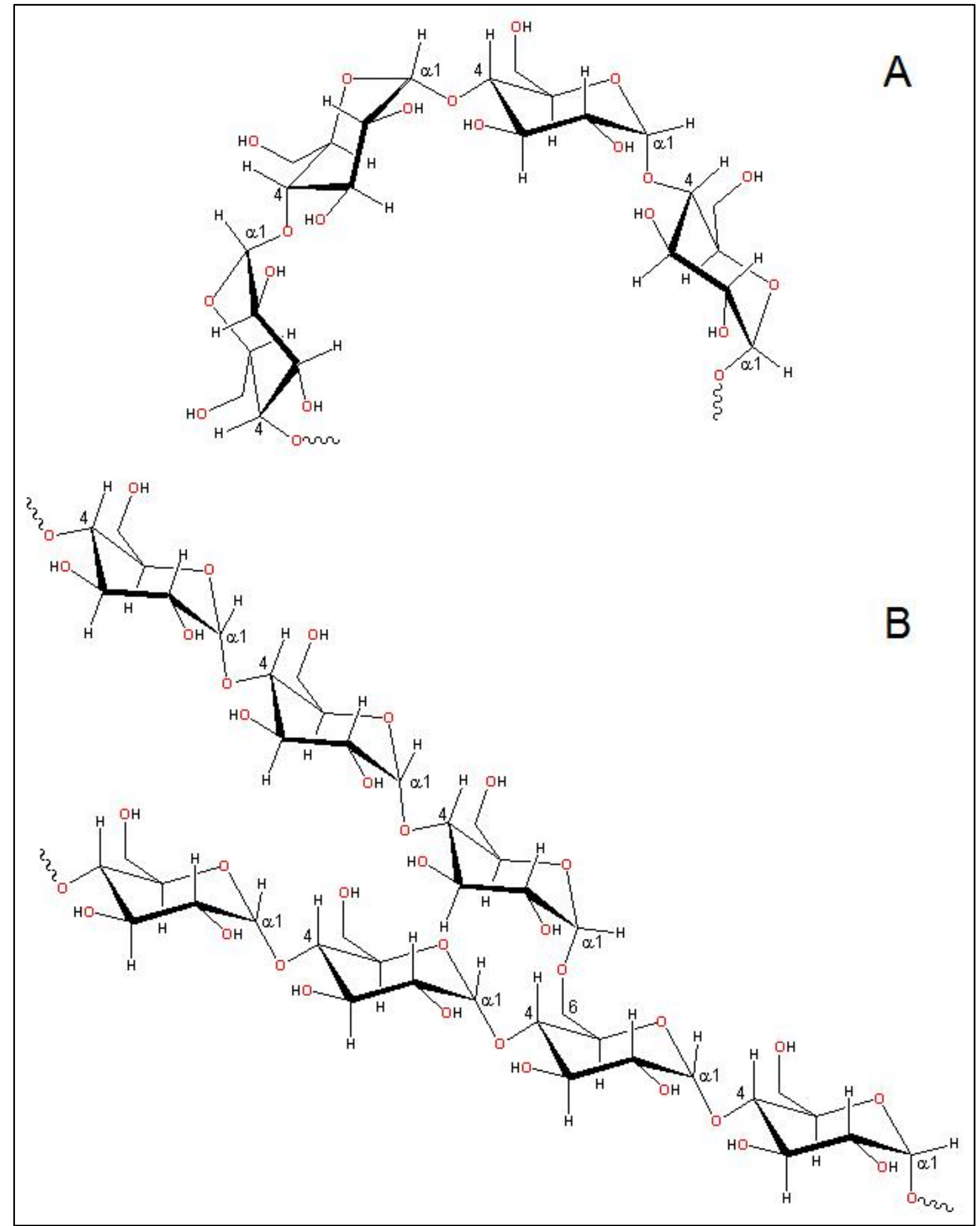

Figura 1. Estrutura do amido. A: Amilose, polímero linear de resíduos de glucose com ligação $\alpha(1 \rightarrow 4)$. B: Amilopectina, mostrando um ponto de ramificação $\alpha(1 \rightarrow 6)$ na cadeia com ligação $\alpha$ $(1 \rightarrow 4)$. Retirado de Amaral (2005).

Convolvulaceae, Malvaceae, Arecaceae e Apiaceae (Tookey et al., 1962). Na indústria de alimentos são utilizadas como espessadores, emulsificadores e estabilizadores, devido à sua capacidade de se ligar à água, ao alto poder espessante, à estabilidade das soluções e à capacidade de interagir com outros 
polímeros para formar gel (Panegassi et al, 2001). Alguns dos muitos alimentos que contêm galactomananos são sorvetes, sobremesas a base de leite, maionese, molhos, alimentos congelados e para animais de estimação. Podem também ser utilizados na fabricação de cosméticos, têxteis, explosivos, papel e medicamentos (Glicksmann, 1962; Chudzikowiski, 1971; Scherbukhin \& Anulov, 1999). As gomas são também muito importantes industrialmente, por serem muito mais baratas que a carragenana e o ágar e, com isso, géis de propriedades específicas podem ser obtidas com uma mistura barata de galactomananos e pequenas quantidades de carragenana ou agarose, reduzindo consideravelmente o custo total (Srivastava \& Kapoor, 2005). As principais fontes comerciais são leguminosas, sendo muito conhecidas a goma guar (Cyamopsis tetragonolobus) e goma caroba (Ceratonia siliqua), cujas razões manose:galactose são, respectivamente, 2:1 e 4:1. Essa é uma característica importante, pois pode interferir em algumas de suas propriedades físicas (Panegassi et al., 2001). Scherbukhin e Anulov (1999) propuseram que os galactomananos poderiam ser usados terapeuticamente em pacientes não dependentes de insulina, pois obtiveram uma redução de 10-15\% na absorção de colesterol quando a dieta era complementada por esse polissacarídeo.

Os chamados mananos "puros" são artificialmente definidos como tendo $90 \%$ ou mais de manose formando uma cadeia linear do tipo $\beta-(1 \rightarrow 4)$ sem ramificações, podendo ou não o restante estar ramificado com galactose, por meio de ligações $\alpha-(1 \rightarrow 6)$. São insolúveis em água e, de certa forma, cristalinos na parede celular. Podem ser encontrados em Arecaceae (Phoenyx dactylifera e Phytelephas macrocarpa) e em café (Coffea arabica) (Reid \& Edwards, 1995) e estão relacionadas à dureza e à proteção dos embriões contra danos mecânicos (Buckerdge \& Reid, 1996).

Dentre os polissacarídeos de reserva de parede celular do grupo dos mananos, os glucomananos são os menos estudados. Eles possuem uma cadeia linear unida por ligações $\beta-(1 \rightarrow 4)$, contendo praticamente quantidades iguais de resíduos $\beta$-glucopiranosil e $\beta$-manopiranosil e podem ser encontradas em sementes de algumas espécies de Liliaceae (Asparagus officinalis e Edymion mutans, Scilla nonscripta), Iridaceae (Iris ochroleuca e I.sibirica), Amaryllidaceae e Agavaceae. (Buckerdge \& Reid, 1996). Um glucomanano, conhecido como "goma Konjac", é obtido de tubérculos de Amorphophallus konjac (Araceae) e é bastante estudado por ser utilizado no Japão, especialmente na preparação de um alimento tradicional 
chamado "kon-nyaku", um gel alcalino de "konjac" (Cui \& Wang, 2006). Sua farinha também é utilizada como espessante, gelificante, texturizador e agente ligante a ágar, além de ser o principal ingrediente em produtos vegetarianos análogos à carne (Izydorczyk et al., 2005).

Os xiloglucanos possuem uma cadeia principal de $\beta$-D-(1 $\rightarrow 4)$-glucano ramificada com ligações $\alpha-(1 \rightarrow 6)$ por resíduos de D-xilopiranosídeos ou $\beta$-Dgalactopiranosídeo-(1 $\rightarrow 2$ )-D-xilopiranosídeos (Hayashi, 1989). Estão presentes em sementes de várias espécies, como beijo-de-frade (Impatiens balsamina Balsaminaceae), copaíba (Copaifera langsdorffii - Leguminosae) e chagas (Tropaeolum majus - Tropaeolaceae). O único xiloglucano comercialmente disponível é o de semente de tamarindo (Tamarindus indica - Leguminosae), que tem sido utilizado como substituto de amido em produtos alimentícios com calorias reduzidas. Também pode ser usado na indústria farmacêutica para controle de liberação de drogas (Izydorczyk et al., 2005). Podem servir de fonte para a produção industrial de xilitol e como aditivos na fabricação de papel (Dietrich et al., 1988; Lima \& Buckeridge, 2001; Lima et al., 2003). Em um estudo com a farinha de semente de uma leguminosa africana (Detarium senegalense), os autores sugerem que sementes ricas em xiloglucano podem ser fontes valiosas de polissacarídeos hidrossolúveis e não amiláceos (Wang et al., 1996). Shirakawa e col. (1998) modificaram as propriedades geleificantes do xiloglucano de sementes de tamarindo, indicando novas possibilidades de uso dos xiloglucanos na indústria alimentícia.

Os (arabino)galactanos podem ser compostos por D-galactanos unidos por ligações $\beta-(1 \rightarrow 3),(1 \rightarrow 6)$ com algumas ligações $\beta-(1 \rightarrow 4)$ ou por ligações $\beta-(1 \rightarrow 4)$ com ramificações de L-arabinofuranose a cada 16-21 resíduos da cadeia principal (Al-Kaisey \& Wilkie, 1992). O intenso uso de arabinogalactanos se dá devido à conhecida goma arábica (em geral, exsudato de caule de Acacia senegal Leguminosae), a mais antiga e conhecida goma natural, que é utilizada nas indústrias alimentícia, farmacêutica e cosmética (Verbeken et al., 2003). Outra fonte comercialmente disponível é uma gimnosperma (Larix occidentalis - Pinaceae), cujos galactanos são utilizados como aditivo de baixa caloria em bebidas, com 0 objetivo de aumentar o conteúdo de fibras (Izydorczyk et al., 2005). Em sementes, eles foram encontrados pela primeira vez em 1892 (Schulze \& Steiger apud Buckeridge et al., 2000c) e desde então têm sido estudados em espécies de lupino 
(Lupinus sp. - Leguminosae) (Hirst et al., 1947; Brillouet \& Riochet, 1983; Al-Kaisey \& Wilkie, 1992; entre outros).

Em relação à função desses polissacarídeos para a planta, o amido desempenha a função exclusiva de reserva, mas os frutanos e os polissacarídeos de reserva de parede celular apresentam funções paralelas. Os frutanos participam no controle osmótico e os polissacarídeos de reserva de parede celular estão associados à dureza (mananos em endospermas de sementes de palmeiras, tomate e alface), relações hídricas (xiloglucanos em cotilédones e galactomananos em endosperma de sementes de leguminosas) e no controle da expansão celular (galactanos nos cotilédones de lupino) (Buckeridge et al., 2000c).

\subsection{Lipídios}

Os lipídios formam, juntamente com carboidratos e proteínas, o grupo de compostos mais importantes nos alimentos e mais freqüentemente encontrados na natureza, tanto nos animais como nos vegetais. Desempenham papéis muito importantes em diversas funções biológicas e ainda se fazem presentes na composição de estruturas celulares, principalmente membranas (Bobbio \& Bobbio, 2003).

Nas plantas, representam uma reserva química de energia livre. Os ácidos graxos, por serem moléculas orgânicas consideravelmente mais reduzidas que os carboidratos, possuem maior potencial de liberação de energia em sua oxidação. Os triacilgliceróis têm rendimento (em relação à massa) aproximadamente duas vezes maior do que os carboidratos. Muitas espécies acumulam óleos em suas sementes em desenvolvimento para atuar como reserva de energia durante a germinação (Somerville et al., 2000). Os lipídios ocorrem nos vegetais com maior freqüência nas sementes, frutos e folhas, e em menor proporção em raízes, caules e flores. As sementes são freqüentemente os órgãos mais ricos em lipídios, constituindo uma das formas de reserva para o embrião (Esau, 1986).

Lipídios na forma de triacilgliceróis são amplamente distribuídos como reservas de carbono e energia química em sementes e frutos, embora eles possam ser encontrados em todos os tecidos vegetais. A única exceção conhecida é a jojoba (Simmondsia chinensis), um arbusto nativo do deserto do sudoeste dos Estados 
Unidos, que acumula, em vez de triacilgliceróis, cera líquida (ésteres de ácidos e alcoóis graxos) em suas sementes como reserva de energia (Ohlrogge et al., 1977). Nas sementes, os locais de armazenamento são os cotilédones (linhaça, colza, cártamo, girassol) ou o endosperma (mamona, coco). Nos frutos, os triacilgliceróis ficam armazenados no mesocarpo que circunda a semente (abacate, oliva). Eles são depositados em corpos oleíferos, também chamados oleossomos ou corpos lipídicos, que são gotas de óleo envoltas por uma camada fosfolipídica única, estabilizadas por proteínas hidrofóbicas chamadas oleosinas, as quais catalisam a mobilização dos ácidos graxos durante a germinação (Abell et al., 1997). A quantidade de óleo varia consideravelmente de mais de $50 \%$ em algumas sementes oleaginosas a 1-2\% nos cotilédones de muitas leguminosas (Heldt, 2005). Nos cereais, nos quais carboidratos são armazenados no endosperma, os triacilgliceróis acumulam-se preferencialmente no embrião. Outros compostos lipídicos encontrados nas sementes podem ser esteróis, fosfolipídios, glicolipídios, tocoferol e esqualeno (Mayer \& Poljakoff-Mayber, 1975).

Triacilgliceróis são ésteres de glicerol aos quais ácidos graxos estão esterificados a cada um dos três grupos hidroxila (Figura 2). Os ácidos graxos são ácidos carboxílicos de cadeias de carbono fortemente reduzidas. Oito deles são comumente encontrados nos lipídios de reserva da maioria das sementes oleaginosas: láurico $(12: 0)^{1}$, mirístico (14:0), palmítico (16:0), esteárico (18:0), oléico (18:1), linoléico (18:2), linolênico (18:3) e erúcico (22:1). Além dos ácidos graxos comuns de 16 e 18 carbonos, algumas plantas também produzem ácidos graxos de 8 a 32 carbonos, que são usualmente acumulados em lipídios de reserva ou em cera epicuticular. Enquanto nas plantas é mais comum lipídios com ácidos graxos insaturados, nas gorduras animais os triacilgliceróis saturados são mais comuns (Broun et al., 1999). Mais de 400 outros ácidos graxos naturais já foram relatados (Aitzetmüller et al., 2003). Alguns são considerados incomuns por diferentes características no comprimento da cadeia (i.e., maior que 18 carbonos, menor que 14), posição ou número de ligações duplas (i.e., poliinsaturados) ou devido à presença de modificações que não ligações duplas (i.e., hidroxilação, grupos epóxi, etc) (Napier, 2007). Muitos desses, como os ácidos láurico (12:0), erúcico (22:1) e

\footnotetext{
${ }^{1}$ Estrutura dos ácidos graxos: o primeiro dígito representa o número de átomos da cadeia carbônica e o segundo, o número de insaturações.
} 
ricinoléico (12-OH, 18:1), são de grande importância comercial. Óleos de sementes contendo ácidos graxos epóxi são de potencial interesse como estabilizadores em formulações plásticas e na preparação de outros compostos de cadeia longa. Óleos de sementes contendo ácidos graxos ciclopropenóides têm atraído atenção devido a seus efeitos biológicos em animais e suas propriedades co-carcinogênicas. Para a planta, uma possível função desses ácidos incomuns é a de proteger a semente contra a herbivoria, por serem tóxicos ou indigestos (Hosamani \& Sattigeri, 2002).

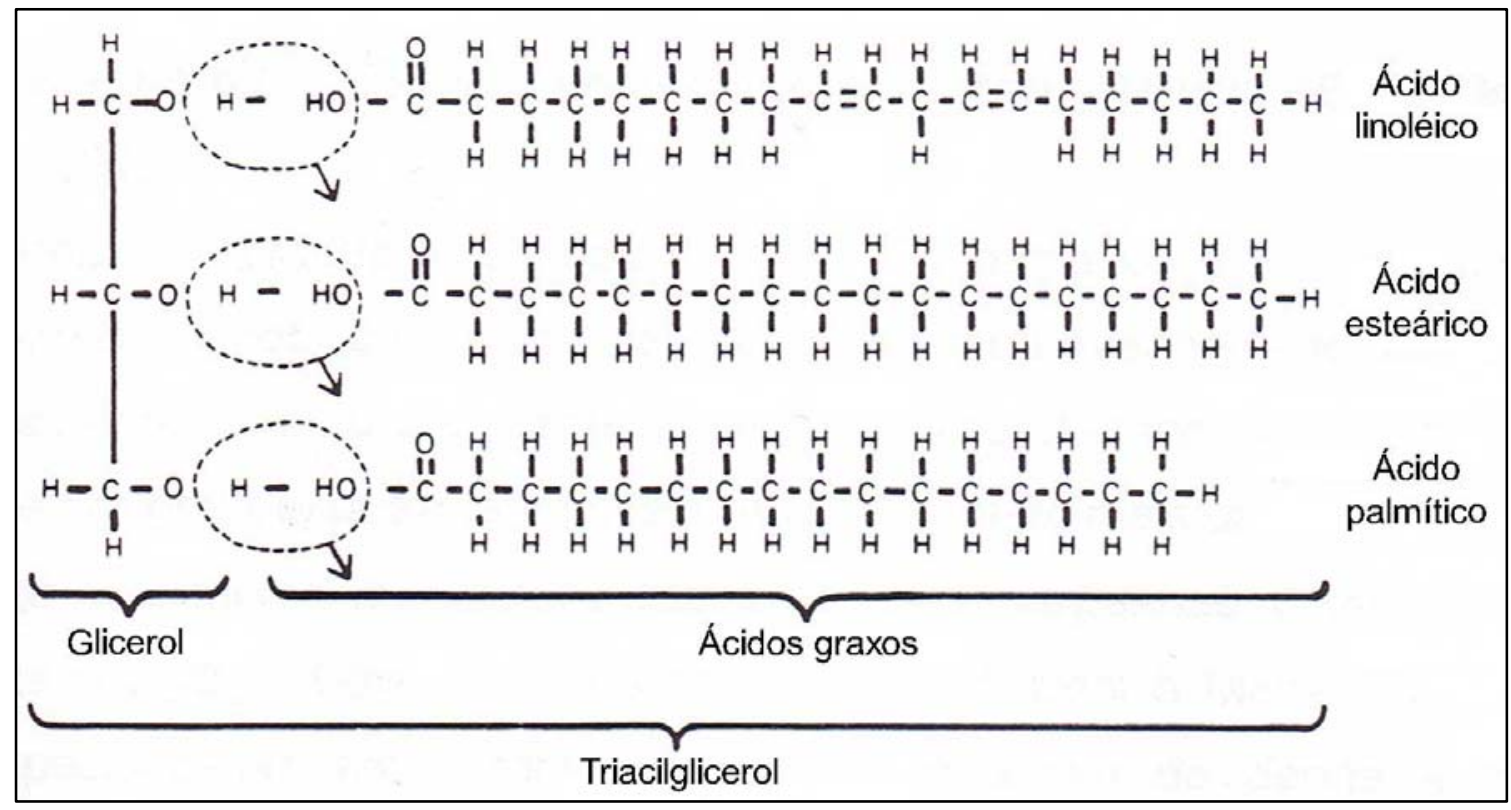

Figura 2: Formação de um triacilglicerol, por reação de esterificação entre três moléculas de ácidos graxos e uma de glicerol. Adaptado de Mayworm (1999).

Lipídios na forma de óleos e gorduras vegetais têm sido utilizados pelo homem há séculos como alimento para humanos e outros animais. A produção anual de óleos e gorduras excede 100 milhões de toneladas, das quais aproximadamente $79 \%$ são de origem vegetal e $21 \%$ de origem animal. A maior parte dos óleos vegetais comestíveis (70 milhões de toneladas) provem de quatro cultivos: soja, canola, palma (dendê) e girassol. Metade dessa produção é engarrafada como óleo de cozinha. Aproximadamente $80 \%$ é destinado ao consumo humano, $6 \%$ para animais e os $14 \%$ restantes são utilizados pela indústria de oleoquímicos, para produzir principalmente sabonetes e outros materiais tensoativos. Outras utilidades industriais dos lipídios são a produção de produtos de limpeza, cosméticos, tintas e vernizes, medicamentos, revestimentos, plásticos e 
especialmente lubrificantes. Tanto para alimentos quanto para aplicações industriais, a composição de ácidos graxos dos óleos determina sua utilidade e, portanto, seu valor comercial. Devido à sua importância econômica, extensa informação está disponível acerca da composição de ácidos graxos de inúmeras sementes oleaginosas (Gunstone, 2002; Kinney, 2006).

Atualmente, acredita-se que o consumo excessivo de alimentos ricos em gorduras ou óleos contendo ácidos graxos saturados com cadeias de 12 a 16 carbonos aumenta a lipoproteína de baixa densidade (LDL) e pode elevar o risco de doenças cardiovasculares (Schaefer, 1997). O ácido esteárico (C18:0) é considerado neutro em relação a seu efeito nos lipídios do sangue (Kris-Etherton et al., 2005), enquanto ácidos graxos monoinsaturados e poliinsaturados tendem a apresentar uma relação inversa com a incidência de doenças coronarianas (Binkoski et al., 2005). Infelizmente, os ácidos poliinsaturados são menos estáveis, principalmente durante a fritura, devido às duplas ligações. A hidrogenação para produção de margarinas leva à formação de ácidos graxos trans-insaturados. $O$ consumo desses ácidos tem conseqüências negativas para a saúde humana (Korver \& Katan, 2006), motivo pelo qual muitas indústrias não estão mais utilizando esses compostos em suas formulações. Entretanto, vale ressaltar que os ácidos linoléico e linolênico são essenciais, pois o homem não possui enzimas que convertem o ácido oléico nesses dois ácidos. No organismo, os ácidos linoléico e linolênico são transformados em ácido araquidônico (20:4) e ácido eicosapentaenóico (20:5), que são precursores de metabólitos eicosanóides, como as prostaglandinas, leucotrienos e tromboxanos. 0 balanço entre os diversos eicosanóides modula a resposta inflamatória. Esses ácidos graxos desempenham ainda papel fundamental no metabolismo celular, incluindo a regulação da fluidez da membrana, transporte de elétrons e oxigênio e adaptação termal (Funk, 2001). Deve-se também levar em consideração a proporção entre ácidos graxos $\omega-3^{2}$ e $\omega-6$ ingeridos. Foi demonstrado que o excesso de consumo de ácidos graxos $\omega-6$ leva a uma redução dos $\omega-3$, com numerosas conseqüências negativas (Lands, 2005). Com tudo isso, percebe-se que um correto balanceamento entre os ácidos graxos (saturados, insaturados, $\omega-3$ e $\omega-6$ ) é um fator crítico na manutenção da saúde (Damude \& Kinney, 2008).

Devido às necessidades nutricionais e industriais, há interesse em aumentar

\footnotetext{
${ }^{2}$ O símbolo $\omega$ indica em qual carbono está a insaturação, contado a partir da extremidade metila.
} 
a porcentagem de óleo obtido das sementes oleaginosas e de se obter óleos com determinada composição de ácidos graxos, por meio de biotecnologia. Existe uma tendência ao desenvolvimento de fontes de óleos monoinsaturados e um sucesso particular envolve a alteração genética da soja, na qual obteve-se um aumento de $10 \%$ para mais de $85 \%$ de ácido oléico do total de ácidos graxos e, ao mesmo tempo, uma redução dos ácidos graxos saturados de mais de $15 \%$ para menos de $5 \%$. Espera-se que os óleos provenientes dessa variedade de soja aumentem os benefícios à saúde e melhorem a estabilidade oxidativa (Miquel \& Browse, 1995; Somerville et al., 2000). Com a recente percepção da necessidade dos ácidos graxos poliinsaturados com cadeias superiores a 18 átomos, tem-se procurado uma angiosperma que os acumule em lipídios de reserva ou de membrana. Atualmente, esses ácidos entram na dieta humana por meio da ingestão de peixes. Entretanto, tendo em vista o crescimento populacional, a pesca excessiva e o impacto ambiental nos sistemas aquaculturais, os peixes criados e os capturados não podem ser considerados uma fonte sustentável de ácidos graxos poliinsaturados (Naylor et al., 2000). Nesse contexto, as sementes oleaginosas transgênicas poderiam ser uma opção, principalmente porque uma baixa porcentagem diária desses ácidos consumidos na forma de óleos vegetais seria suficiente para satisfazer as necessidades nutricionais humanas (Abbadi et al., 2001).

Nas últimas décadas, a redução dos combustíveis fósseis tem estimulado a procura por substitutos dos derivados de petróleo e isso resultou em fontes alternativas de energia, como o biodiesel, hidrogênio e bioetanol. Como o preço do combustível de petróleo está aumentando a cada dia, o incentivo à pesquisa e uso de combustíveis alternativos também vem aumentando. O biodiesel é produzido a partir de fontes biológicas renováveis, como óleos vegetais. O biodiesel é biodegradável, não tóxico, essencialmente livre de enxofre e compostos aromáticos. No Brasil, o óleo de soja é a fonte mais cogitada para a produção de biodiesel. Outras fontes, como os óleos de girassol, amendoim, dendê, coco, babaçu e, especialmente, mamona, podem ser usados em futuro próximo (Ramadhas et al., 2004; Pinto et al., 2005; Akoh et al., 2007). 


\subsection{Proteínas}

Proteínas são componentes complexos e essenciais a todas as células vivas. Apesar da complexidade das moléculas de proteína, na natureza existem apenas 20 aminoácidos encontrados com freqüência. Desses, dez são considerados essenciais para o homem (arginina, fenilalanina, histidina, isoleucina, leucina, lisina, metionina, treonina, triptofano e valina), pela necessidade de obtê-los por meio da dieta. É importante ressaltar que a arginina só é essencial para indivíduos jovens e em crescimento, mas não para adultos e que a cisteína e a tirosina são importantes, pois também não são sintetizadas pelo corpo, porém não são consideradas verdadeiramente essenciais, porque podem ser produzidas a partir de metionina e fenilalanina, respectivamente (Lehninger, 1995).

Sabe-se que para uma nutrição adequada, é preciso ter um bom balanço entre esses aminoácidos. Em relação a isso, as proteínas que apresentam a proporção de aminoácidos essenciais mais próxima à das nossas proteínas é a do ovo e, em geral, os alimentos de origem animal são também ideais como fontes de proteínas. Entretanto, são proteínas de origem vegetal as que fornecem mais de $70 \%$ de proteína da dieta humana e a maior parte disso é constituída por proteínas de reserva de sementes de cereais e leguminosas. Essa é uma das melhores combinações, pois as proteínas dos cereais são deficientes em treonina, triptofano e particularmente em lisina, enquanto as leguminosas são limitadas em aminoácidos sulfurosos, metionina e cisteína (Heldt, 2005) e, em conjunto, forma-se uma composição de aminoácidos essenciais muito mais próxima à do ovo.

Levando em consideração os diferentes tipos de dietas no mundo e o fato de a carne ser um luxo como alimento para diversos países e populações, as proteínas vegetais são importantes por serem, em muitos casos, a principal ou única fonte de aminoácidos essenciais na alimentação. Segundo Sander e col. (1987 apud Habben \& Larkins, 1995), geralmente existe uma relação inversa entre as condições econômicas de uma sociedade e o consumo de proteínas de sementes. Populações de países em desenvolvimento consomem proteínas de sementes em proporção maior do que as de países desenvolvidos, que têm condições mais favoráveis de consumir proteínas de origem animal. A proteína vegetal é mais econômica de se produzir (para a produção de $1 \mathrm{~kg}$ de proteína animal, são necessários 3 a $20 \mathrm{~kg}$ de proteína vegetal), transportar e armazenar. Além disso, dado o crescimento 
populacional e o concomitante desgaste dos recursos naturais do mundo, é necessário mais proteínas e de melhor qualidade (CHEFTEL et al., 1989 apud MAYWORM, 1999).

As sementes são ótimas fontes de proteínas, pois em contraste com outros órgãos vegetais, armazenam proteínas sob forma concentrada. As folhas possuem apenas $3-5 \%$ de proteínas e os tubérculos, $5 \%$, enquanto sementes de cereais contêm $8-15 \%$ de proteína e sementes de leguminosas, $20-30 \%$, podendo chegar a $40 \%$ na soja. Apesar do conteúdo médio de proteínas dos cereais ser baixo, elas representam aproximadamente $70 \%$ do total de proteínas "colhidas", devido à sua grande produção total (John, 1992 apud Habben \& Larkins, 1995).

Um dos primeiros trabalhos publicados sobre proteínas de sementes foi o de Beccari em 1745 (apud Vickery, 1945), mas foi o trabalho de Osborne, que se iniciou em 1891, que colocou os estudos de proteínas de sementes em uma base bioquímica consistente. Osborne e seus colegas isolaram as proteínas vegetais de acordo com a solubilidade em diversos solventes e as classificaram em frações extraídas em água pura (albuminas), soluções salinas diluídas (globulinas), soluções alcoólicas (prolaminas) e soluções alcalinas ou ácidas diluídas (glutelinas) (Heldt, 2005). Atualmente, ainda não existe um sistema de classificação universalmente aceito, mas Shewry (2000) considera mais válido dividir as proteínas primeiro em relação à sua função e, para as proteínas de reserva, utilizar a classificação de Osborne modificada. Essa classificação divide as proteínas de reserva em quatro grupos, definidos pelas frações de Osborne e por seus coeficientes de sedimentação, que representam a medida de seu tamanho molecular. Os quatro grupos são as prolaminas, as albuminas $2 \mathrm{~S}$ e as globulinas $7 \mathrm{~S}$ e $11 \mathrm{~S}$.

Muitas sementes acumulam dois ou mais tipos de proteínas de reserva, embora um tipo seja geralmente o mais abundante. As globulinas $11 \mathrm{~S}$ são as mais amplamente distribuídas, estando presentes em grande variedade de angiospermas, tanto em tecidos de origem endospérmica quanto embrionárias. As globulinas $7 \mathrm{~S}$ estão presentes em muitas famílias, mas são particularmente características de sementes de leguminosas e junto com as 11S formam a maior parte das proteínas de reserva. Essas globulinas são tão características de sementes de leguminosas que, em geral, são chamadas respectivamente de vicilinas (de Vicia spp.) e leguminas. Já as albuminas $2 S$ só foram caracterizadas em sementes de algumas espécies e as prolaminas têm ocorrência ainda mais restrita, estando presentes 
apenas em sementes de cereais e outras espécies de gramíneas (Millerd, 1975; Ashton, 1976).

Entre os outros tipos de proteínas de sementes, vários têm função protetora, ou estrutural ou metabólica. Dentre os protetores, os inibidores de proteinases são, provavelmente, os mais abundantes e amplamente distribuídos, sendo particularmente comuns em sementes de leguminosas, proporcionando resistência contra herbivoria. Existem também endo-hidrolases, como as $\beta-1,3-g l u c a n a s e s$ e endoquitinases, que parecem ter propriedades antifúngicas; lectinas, que se ligam à glicoproteínas do intestino e interferem na absorção dos nutrientes; proteínas inativadoras de ribossomo; proteínas inibidoras de poligalacturonase, entre outras. Outras proteínas estruturais ou metabólicas incluem componentes estruturais da parede celular, transportadores e proteínas estruturais associadas a membranas de células e organelas, e enzimas (Shewry \& Lucas, 1997). Essas proteínas e outras substâncias eventualmente presentes nas sementes, como os taninos, funcionam como agentes anti-nutricionais e podem diminuir a qualidade nutricional das proteínas.

Melhorar a qualidade das proteínas das sementes é muito importante e por isso, muito esforço vem sendo feito na tentativa de entender os aspectos genéticos, bioquímicos, fisiológicos, moleculares e nutricionais dessas proteínas. Apesar do progresso no conhecimento molecular e bioquímico das mutações em cereais e leguminosas e o desenvolvimento de genótipos nutricionalmente superiores, a maioria das linhagens desenvolvidas não tiveram muito sucesso. Para as linhagens de soja melhoradas, por exemplo, um grande aumento nos teores de metionina e cisteína ainda é necessário. Independentemente das melhorias que são possíveis por meio do uso de mutações que ocorrem naturalmente e da reprodução tradicional, não existe dúvida que existem limites em relação ao que se pode obter com essas técnicas. Além disso, não se pode ter certeza de que reproduzindo cereais com baixo teor de prolaminas, por exemplo, não se terá um impacto negativo em aspectos físicos importantes da semente e nas propriedades da farinha (Habben \& Larkins, 1995).

Investir em outras espécies também pode ser interessante e alguns exemplos que vem sendo estudados são a amaranta (Amaranthus spp. Amaranthaceae), que tem bom potencial por crescer rapidamente em regiões onde plantações temperadas não crescem, ter alto rendimento de proteína e de lisina (De 
Mucciarelli et al., 1990) e a quinoa (Chenopodium quinoa - Amaranthaceae), devido à alta qualidade de suas proteínas, podendo suplementar e freqüentemente substituir a proteína animal da dieta, sendo provavelmente tão boa nutricionalmente quanto o leite (Friedman, 1996). Essas espécies, por terem baixo ou nenhum potencial para produção em grande escala, são consideradas "culturas órfãs" e não têm atraído o interesse dos produtores. Entretanto, Shewry (2000) ressalta que elas não devem ser negligenciadas pelos cientistas como fontes valorosas de genes para o melhoramento das espécies convencionais.

\subsection{Outros componentes}

Além dos principais compostos mencionados, as sementes podem conter diversas outras substâncias. Todas as sementes contêm minerais, vitaminas e aminoácidos livres. Muitas possuem alcalóides, ácidos orgânicos, fitosteróis, pigmentos e diversos compostos fenólicos como, por exemplo, derivados de cumarina, ácido clorogênico e fenóis simples como os ácidos ferúlico, caféico e sinápico, além de taninos (Mayer \& Poljakoff-Mayber, 1975). Alguns desses compostos são tóxicos ou anti-nutricionais e podem afetar a qualidade nutricional das sementes.

\section{Leguminosas}

A família Leguminosae Adanson é a terceira maior entre as angiospermas. São praticamente cosmopolitas, estando em todos os continentes, exceto Antártica, e ocorrendo em diversos habitats, exceto marinho e epifítico (Wink \& Mohamed, 2003). A família é representada por 19.325 espécies, reunidas em 727 gêneros e 36 tribos (Lewis et al., 2005). No Brasil, há 2.100 espécies reunidas em 188 gêneros (Lima, 2000 apud Filardi, 2005). O termo Leguminosae, apesar de não apresentar a desinência oficial para a categoria de família, é bastante difundido e alguns estudiosos defendem seu uso, pois o nome Fabaceae pode ser entendido como referente à Papilionoideae (=Faboideae) (Lewis \& Schrire, 2003). Apesar de alguns autores considerarem como três famílias distintas, há um crescente número de evidências que apóiam o grupo como sendo monofilético (Wojciechowski et al., 
2004), dividindo-a em três subfamílias (Papilionoideae, Mimosoideae e Caesalpinioideae). Dessas, as duas primeiras formam clados monofiléticos e a terceira forma um grupo parafilético basal (Louis et al., 2007). A principal característica que une a família é o fruto (legume), formado por um único carpelo, com um lóculo, placentação marginal ao longo da sutura adaxial e vários óvulos, embora alguns membros tenham frutos tão modificados que raramente lembrem legumes (Polhill, 1994). Possuem alto metabolismo de nitrogênio e aminoácidos incomuns, geralmente vivendo em simbiose com bactérias fixadoras de nitrogênio (Rhizobium, entre outras), formando nódulos nas raízes. Estima-se que essa associação esteja presente em 93\% das espécies de Papilionoideae e em menor porcentagem nas outras subfamílias (Judd et al., 2002).

Leguminosae reúne $25 \%$ dos táxons de fanerógamas do cerrado, tendo sido relatadas 777 espécies (23,5\%) pertencentes a 101 gêneros (20\%) (Mendonça et al., 1998). É considerada uma das famílias de maior riqueza florística do bioma, juntamente com Asteraceae e Poaceae (Mantovani, 1983; Batalha et al., 1997; Batalha \& Mantovani, 2001; Ratter et al., 2003). Ao contrário das demais famílias citadas, Leguminosae é expressiva tanto na flora herbáceo-subarbustiva, quanto na flora arbustiva-arbórea, tendo importância na dinâmica das comunidades das diferentes fitofisionomias que compõem o cerrado, tanto as externas (campo limpo e cerradão) quanto as intermediárias (campo sujo, campo cerrado e cerrado sensu stricto) (Mantovani, 1983; Batalha et al.,1997; Batalha \& Mantovani, 2001; Tannus \& Assis, 2004).

Em termos econômicos, é a segunda família mais importante ao homem, perdendo apenas para Poaceae. Mais de 80 espécies são consumidas no mundo e representam a segunda maior fonte de alimento. Aproximadamente 20 espécies são cultivadas e as mais importantes são soja, amendoim, lupino, lentilhas e diversos feijões (Sosulski \& Sosulski, 2006). Das três subfamílias, a mais importante na alimentação é Papilionoideae. Diversas sementes de leguminosas arbóreas vêm sendo estudadas, tendo em vista sua utilização na alimentação humana ou animal em algumas regiões, em épocas de alimentação escassa, ou ainda como forma de valorização e preservação dos recursos naturais. No Brasil, Togashi e Sgarbieri (1994) estudaram a semente de baru (Dypterix alata), uma espécie do cerrado brasileiro, concluindo que pode ser uma importante fonte de proteínas e carboidratos, Matuda e Netto (2005) analisaram sementes de jatobá-de-cerrado 
(Hymenaea stigonocarpa) e encontraram alto teor de fibras (possivelmente xiloglucanos e galactomananos, segundo os autores), que pode levar ao aproveitamento rentável dessas sementes. Os membros das outras subfamílias são ocasionalmente utilizados como alimento, mas são mais comumente empregadas no melhoramento do solo (aumentando os níveis de nitrogênio), como forrageiras, pelas suas gomas e resinas, como fonte de corante e combustível. Dentre as leguminosas, existem também muitas espécies ornamentais, outras são valiosas fontes de madeira e muitas são conhecidas por suas propriedades medicinais, já tendo sido isoladas e caracterizadas milhares de substâncias (Harborne, 1994; Simpson \& Ogorzaly, 2001; Judd et al., 2002).

Em relação aos carboidratos, suas sementes contêm de 50 a $60 \%$ em peso seco. Mono e oligossacarídeos representam apenas uma pequena porcentagem do total de carboidratos. Uma quantidade substancial dos carboidratos das leguminosas é componente das fibras totais (3 a 10\%), e em menor quantidade estão incluídas as substâncias pécticas, arabinogalactanos e xiloglucanos (Reddy et al., 1984; Sathe et al., 1984). Um polissacarídeo típico em endosperma é o galactomanano (Buckeridge \& Dietrich, 1990). Entre os açúcares, os oligossacarídeos da série rafinósica estão em considerável quantia na maior parte das leguminosas. A flatulência causada por esses oligossacarídeos é o maior impedimento para um maior consumo das leguminosas. Entretanto, elas podem ser degradadas através do calor e cozimento (Vidal-Valverde et al., 1993). O amido é abundante em alguns grãos (Reddy et al., 1984), porém dentre as leguminosas, apenas 27 gêneros apresentam amido (Bailey, 1971).

De acordo com Polhill et al. (1981), existe uma tendência evolutiva dentro da família em acumular reservas em cotilédones. Em geral, as sementes de espécies de Caesalpinioideae, que é considerada a mais basal, tende a acumular grande quantidade de galactomanano nas paredes celulares do endosperma. Dentro dessa subfamília, também é possível observar que algumas tribos (Amherstieae e Detariae) tendem a não ter endosperma (ele é consumido durante a maturação) e a acumular grandes depósitos de xiloglucanos nas paredes celulares dos cotilédones (Copaifera, Hymenaea). Acredita-se que as outras duas subfamílias desenvolveramse a partir de Caesalpinioideae e em Papilionoideae é possível encontrar espécies ou tribos inteiras com grande quantidade de galactomananos armazenadas nas paredes celulares de endospermas muito espessos (muitas espécies de Crotalarieae 
e Sesbanieae, por exemplo). Mesmo assim, espécies próximas armazenam amido em grânulos localizados no citoplasma de células do cotilédone (Vicia faba, Pisum sativum e Glycine max, por exemplo). Assim, segundo Buckeridge \& Reid (1996), a função de reserva parece ter sido transferida durante a evolução, do endosperma (galactomanano em Caesalpinioideae, Mimosoideae primitivas e algumas tribos de Papilionoideae) para o cotilédone em algumas Caesalpinioideae (xiloglucano na parede celular) e algumas tribos de Papilionoideae (galactanos em parede celular de lupino e amido no citoplasma de algumas espécies de Phaseoleae).

Muitos são os trabalhos sobre os polissacarídeos de reserva de parede celular quanto à ocorrência, estrutura, metabolismo, funções e aspectos ecológicos. Dentre esses polissacarídeos, os galactomananos têm se mostrado muito importantes em Leguminosae, principalmente em estudos quimiotaxonômicos e evolutivos (Buckeridge et al., 1995b). Buckeridge e col. (2000a) realizaram um levantamento de dados (incluindo diversas espécies nativas) sobre a ocorrência de galactomananos em sementes de leguminosas e concluíram que alto rendimento de galactomananos menos ramificados foram preservados em Caesalpinioideae, enquanto em Papilionoideae uma crescente ramificação foi associada a uma redução no rendimento. Em Mimosoideae, os galactomananos desapareceram virtualmente nas tribos mais avançadas. Na revisão de Srivastava e Kapoor (2005), os autores comentam que alguns trabalhos revelaram ainda que em Papilionoideae são encontrados altos rendimentos de goma e proteína, enquanto em Mimosoideae e Caesalpinioideae são encontrados alto rendimento de goma, mas baixo rendimento de proteínas.

As espécies mais estudadas quanto aos aspectos anatômicos e bioquímicos do armazenamento, biossíntese e degradação do galactomanano são Cyamopsis tetragonolobus (goma guar), Ceratonia siliqua (goma caroba) e Trigonella foenumgraecum (para uma revisão, ver Buckeridge et al., 2000c), principalmente em função de sua importância econômica. Panegassi e col. (2001) estudaram uma espécie nativa do cerrado, Dimorphandra mollis, e relataram seu potencial de utilização nas formulações de alimentos, devido a seu alto rendimento $(83,2 \%)$ e proporção manose:galactose comparáveis às da goma guar e caroba.

Outro polissacarídeo bastante estudado em leguminosas é o xiloglucano, principalmente o de tamarindo (Tamarindus indica), copaíba (Copaifera langsdorffii) e jatobá (Hymenaea courbaril). Buckeridge e col. (1992) mostraram que os 
xiloglucanos de copaíba são estruturalmente similares aos do tamarindo. Posteriormente, Buckeridge e col. (1997) analisaram os xiloglucanos de jatobá e reportaram que eles apresentam características estruturais únicas.

Quanto aos galactanos, muitos estudos vêm sendo realizados desde 1892 em espécies de lupino (Lupinus sp.) quanto à sua estrutura (Al-Kaisey \& Wilkie, 1992) e mobilização durante a germinação (Buckeridge \& Reid, 1994), mas pouco ou nada sobre sua utilização econômica. Sabe-se que também estão presentes como carboidratos de reserva nas paredes celulares dos cotilédones da soja (Cochrane, 2000) e em outras leguminosas, como Acosmium dasycarpum (Buckeridge \& Dietrich, 1990).

As sementes de leguminosas geralmente possuem baixo teor de lipídios. De 137 famílias estudadas por Jones e Earle (1966), em uma abrangente investigação química sobre a composição de sementes, as leguminosas ficaram na $122^{a}$ posição. Dentre as 704 amostras de leguminosas analisadas, a média de quantidade de lipídios na semente foi de apenas $5,5 \%$ e o conteúdo de óleo de muitas espécies usadas na alimentação é de 1 a 2 \% (Sosulski \& Sosulski, 2006). Entretanto, a soja é a semente oleaginosa mais conhecida e utilizada em todo o mundo, e o amendoim também figura entre as principais sementes oleaginosas mais utilizadas para a produção de óleos vegetais comestíveis (Wolff \& Kwolek, 1971). A semente de soja contém 16-22\% e o amendoim 45-50\% de óleo (Pokorný, 2006).

Earle e Jones (1962) e Jones e Earle (1966) fizeram compilações de dados acerca da quantidade de óleo e proteína de sementes de leguminosas e concluíram que, com algumas exceções, as sementes de leguminosas com baixo teor de óleo, abaixo de 2,7\%, provavelmente contém mais amido, enquanto outras com mais óleo, salvo algumas exceções, provavelmente não serão amiláceas. Também relataram que sementes não amiláceas de maior dimensão provavelmente possuirão maior teor de óleo, e as pequenas, maior teor de proteína. Wolff e Kwolek (1971) apóiam essa conclusão, mas indicam que ela se aplica igualmente às sementes amiláceas. Além disso, esses autores sugeriram que sementes leguminosas com baixo teor de óleo provavelmente têm altas porcentagens de galactomananos. Ainda segundo Wolff e Kwolek (1971), o teor de óleo das sementes de leguminosas arbóreas e arbustivas é maior que o de leguminosas de hábito menor. Sementes de leguminosas tropicais tendem a ser mais oleaginosas que as temperadas.

Em relação à composição de ácidos graxos, os ácidos oléico e linoléico são 
os principais componentes. Juntos constituem, em média, $65 \%$ do total de ácidos graxos presentes. A porcentagem desses dois ácidos é inversamente correlacionada - alguns óleos de leguminosas são ricos em linoléico enquanto em outros o oléico é o mais abundante. Leguminosas tropicais arbóreas e trepadeiras aparentemente tendem a conter mais ácido oléico que linoléico, enquanto o inverso é verdadeiro para as temperadas e herbáceas (Wolff \& Kwolek,1971; De Angelis, 2001).

Hilditch e Williams (1964 apud Wolff \& Kwolek,1971) verificaram que o ácido linolênico varia de zero a $35 \%$ do total de ácido graxos e que altas concentrações desse ácido estão associadas especialmente a pequenas leguminosas herbáceas como trevo, alfafa e ervilhaca. Muitos óleos de sementes de leguminosas caracteristicamente contêm substanciais quantidades de ácidos graxos saturados, especialmente com cadeias longas (20, 22 e 24 átomos de carbono), mas o ácido predominante e a quantidade presente variam enormemente entre os diferentes gêneros.

O óleo de soja é um dos mais estudados, devido à sua importância econômica. É rico em ácido linoléico, mas pode ter de 6 a 10\% de ácido linolênico que, por ser considerado indesejável para a maior parte dos propósitos alimentícios, teve seu teor reduzido a $3-4 \%$ ou até $2 \%$ por meio de melhoramento. Dessa forma, apresenta maior estabilidade oxidativa e características organolépticas melhores. Um óleo com alto teor de ácido esteárico (15-30\%) também foi desenvolvido na esperança de ser utilizado para a produção de margarinas e outros produtos alimentícios normalmente hidrogenados, sem a necessidade de hidrogenação (Gunstone, 1997).

Em um estudo com espécies de cerrado, Mayworm e Salatino (1996a) analisaram duas espécies de Papilionoideae, Acosmium subelegans e Dalbergia miscolobium, as quais apresentaram teores relativamente altos de óleos (11,6 e 22,9 $\%$, respectivamente). Nesse mesmo estudo, o autor observou o predomínio sistemático de ácido palmítico nas espécies de Caesalpinioideae, Papilionoideae e Mimosoideae, revelando a tendência muito comum de maior incidência de ácidos graxos de cadeias mais curtas e saturadas em espécies do cerrado. Mais recentemente, ácidos graxos incomuns têm sido encontrados em espécies de leguminosas, como o ácido coronárico e ácidos graxos ciclopropênicos em sementes de Acacia arabica da Índia (Hosamani et al., 2002), ácidos vernólico, malválico e estercúlico em Cassia marginata e C.corymbosa (Hosamani \& Sattigeri, 2002) e 
ácidos ricinoléico, malválico e estercúlico em Crotalaria striata (Hosamani \& Ramesh, 2001).

Quanto às proteínas, em geral, leguminosas são consideradas fontes relativamente abundantes, tanto para humanos quanto para animais, pois contêm 18 a $25 \%$ de proteínas (podendo chegar a $40 \%$ na soja), aproximadamente o dobro dos cereais (7-15\%) (Shrestha et al., 2002). Algumas dessas leguminosas são o amendoim (Arachis hypogea), soja (Glycine max), feijão (Phaseolus vulgaris), ervilha (Pisum sativum), lentilha (Lens culinaris), entre outras (Akpinar et al., 2001). O alto valor nutritivo das leguminosas e seu uso como suplemento protéico em alimentos ou componentes de farinhas as tornam importantes na pesquisa (Naivikul \& D’appolonia, 1978).

Sementes de leguminosas contêm três principais classes de proteínas de reserva: vicilinas, leguminas e lectinas. Juntos, esses componentes constituem mais de $80 \%$ do total de proteínas na semente e estão, portanto, entre os componentes que fornecem a principal contribuição para a qualidade nutricional das sementes e para as propriedades funcionais dos produtos derivados deles. As vicilinas e leguminas estão presentes na maioria das leguminosas, mas sua abundância relativa pode variar muito, estando algumas espécies desprovidas de um ou outro complexo de proteínas (Dudman \& Millerd, 1975). Já as lectinas estão amplamente distribuídas na natureza e podem ser encontradas na maior parte dos tecidos vegetais em pequenas quantidades. Embora as sementes de leguminosas normalmente contenham relativamente baixas quantidades de lectinas, grandes quantidades podem ser encontradas na tribo Phaseolae (Vitale \& Bollini, 1995).

As proteínas das leguminosas têm uma composição de aminoácidos similares. Todas contêm baixas concentrações de aminoácidos sulfurados, metionina e cisteína, os aminoácidos limitantes nas leguminosas. Todas as espécies de leguminosas são ricas em ácido aspártico/asparagina e ácido glutâmico/glutamina (Derbyshire et al., 1976 apud Carbonaro et al., 1997). A concentração de lisina é elevada nas sementes da maioria das leguminosas, sendo considerada de grande valor na complementação das proteínas dos cereais, que de um modo geral são pobres em lisina. A metionina é considerada o aminoácido limitante do valor biológico dessas proteínas por ser nutricionalmente essencial para o organismo animal e a cisteína, apesar de poder ser sintetizada pelos animais, assume muita importância na alimentação, pois sua síntese se dá a partir da 
metionina, tornando esse aminoácido essencial ainda mais limitante. É importante considerar, na dieta, a soma dos dois aminoácidos sulfurados e não apenas a metionina. Nas sementes de leguminosas, em geral, a soma dos aminoácidos sulfurados está muito abaixo do necessário para se ter a melhor utilização biológica das proteínas, sem modificar a concentração dos demais aminoácidos (Sgarbieri, 1980). Além dessa deficiência de aminoácidos, o aproveitamento nutricional de sementes de leguminosas pode ser limitado pela presença de fatores antinutricionais, como os inibidores de tripsina, taninos, fitatos e lectinas e a baixa digestibilidade da proteína. Essa última pode ser significativamente melhorada após tratamento térmico das sementes (Khan et al., 1979; Singh \& Singh, 1992; Liener, 1994; Shoshima et al., 2005).

\section{Cerrado}

O Brasil possui cinco áreas de grande abundância de plantas nativas, estando entre elas o bioma cerrado, que é apontado como grande detentor de diversidade biológica e conhecido como savana brasileira, sendo a formação savânica de maior diversidade vegetal do mundo (Guarim Neto \& Morais, 2003). O cerrado é também o segundo maior bioma em área do país, ocupando em torno de 20 a $25 \%$ do território nacional (cerca de 2 milhões de $\mathrm{km}^{2}$ ), distribuindo-se em duas áreas principais, a área "core" e a área periférica. A área "core" ou nuclear, essencialmente de cerrados, no Planalto Central, ocupa 1,5 milhões de $\mathrm{km}^{2} \mathrm{e}$ abrange parte dos estados de Goiás, Tocantins, Mato Grosso, Mato Grosso do Sul, Minas Gerais, Bahia, Maranhão, Piauí e Rondônia. A área periférica compreende manchas pequenas que distribuem-se pelos estados do Amazonas, Amapá, Roraima, Alagoas, Bahia, Ceará, Paraíba, Pernambuco, São Paulo e Paraná (Ferri, 1977).

A flora do cerrado ainda é incompletamente conhecida, embora um grande número de espécies já tenha sido descrita (Coutinho, 2002). Estima-se que a diversidade florística do cerrado seja de 10 mil espécies, superior à grande parte de outras floras mundiais, sendo que 4400 são endêmicas e respondem por $1,5 \%$ da diversidade vegetal (Myers et al., 2000b). Entre as famílias de maior destaque estão Leguminosae, entre as lenhosas, e Poaceae, entre as herbáceas (Coutinho, 2002). Exceto por certas áreas de floresta pluvial tropical, é a vegetação mais rica do 
mundo em termos de espécies vasculares por hectare. Em virtude dessa excepcional riqueza biológica, o cerrado é considerado um dos hotspots mundiais, tornando-se uma das 25 áreas do mundo consideradas críticas para a conservação, em conseqüência da alta pressão antrópica a que vem sendo submetido (Oliveira \& Duarte, 2004).

Estima-se que até 2002 tenham sido devastados 54,9\% da área original de cerrado no país (Machado et al., 2004, valores superestimados). No estado de São Paulo, as diferentes formações de cerrado recobriam originalmente cerca de $14 \%$ do território paulista e em 1993, apenas 1,17\%, distribuídos em 8.353 fragmentos de cerrado sensu stricto, cerradão e campo cerrado. Apenas cerca de $6 \%$ desses remanescentes estão localizados em Unidades de Conservação e Produção Estaduais (São Paulo, 1997; Kronka et al. 1998). Kaplan e col. (1994) relataram que somente $1,5 \%$ da extensão total no país eram protegidos por lei e Machado e col. (2004) estimam que o bioma deverá ser totalmente destruído em 2030, caso as tendências de ocupação continuem causando uma perda anual de 2,2 milhões de hectares de áreas nativas.

Desde a década de 1990, governos e diversos setores organizados da sociedade debatem como conservar o que restou do Cerrado, com a finalidade de buscar tecnologias embasadas no uso adequado dos recursos hídricos, na extração de produtos vegetais nativos, nos criadouros de animais silvestres, no ecoturismo e outras iniciativas que possibilitem um modelo de desenvolvimento sustentável e justo (São Paulo, 1997).

Estudos que vêm sendo desenvolvidos apontam para o seu grande potencial econômico (Dias, 1992 apud São Paulo, 1997), especialmente nas áreas de:

- alimentos - já se conhecem cerca de 80 espécies vegetais que fornecem frutos, sementes ou palmitos que servem para a alimentação do homem;

- fibras;

- cortiça - existem cerca de 20 espécies que já são utilizadas para este fim;

- taninos (e.g. Stryphnodendron adstringens);

- gomas, resinas, bálsamo e látex, óleos e gorduras;

- uso medicinal - mais de 100 espécies vegetais são usadas para a cura e prevenção de doenças;

- plantas ornamentais; 
- artesanato;

- apicultura.

Nesse contexto, é de urgente necessidade a criação de mais áreas de preservação do cerrado e de extrema importância o desenvolvimento de pesquisas a respeito de usos econômicos potenciais para as espécies deste bioma (Mayworm \& Salatino, 1996a).

Vale ressaltar que, para alimentação, o número de espécies cultivadas em larga escala é extremamente limitado. Por outro lado, atualmente está em curso uma drástica redução da biodiversidade, sem que se saiba o real potencial de aproveitamento das espécies (Heiser Junior, 1977). No cerrado, a criação de gado era a principal causa de desmatamento até 1985, porém nos anos recentes, as pressões têm vindo do grande aumento das plantações de soja (Machado et al, 2004). O relatório de Machado e col. (2004) ainda alerta que as culturas tradicionais estão cedendo lugar para modernas culturas mecanizadas como a soja, algodão, milho, milheto, sorgo e girassol. Em São Paulo, a cana-de-açúcar para a produção de etanol tem substituído os pastos, representando outro importante fator de agressão aos cerrados (Durigan et al., 2007).

\section{OBJETIVOS}

O presente trabalho tem como objetivos determinar o teor de carboidratos, amido, lipídios e proteínas e a composição de ácidos graxos das sementes de leguminosas do cerrado, priorizando aspectos de potencial econômico. 


\section{MATERIAL E MÉTODOS}

\section{Coleta e identificação do material}

A coleta do material botânico foi realizada na Reserva Biológica de Mogi Guaçu, uma área marginal de cerrado que ocupa 343 ha no retângulo $47^{\circ} 08^{\prime}$ $47^{\circ} 12^{\prime} \mathrm{W}$ e $22^{\circ} 15^{\prime}-22^{\circ} 16^{\prime} \mathrm{S}$, município de Mogi Guaçu, no interior da Estação Experimental de Mogi Guaçu, Fazenda Campininha, administrada pelo Instituto de Botânica da Secretaria de Agricultura e Abastecimento do Estado de São Paulo. A vegetação é predominantemente aberta e varia de campo cerrado até cerrado sensu stricto. As altitudes dentro da área da reserva variam entre 560 e $700 \mathrm{~m}$, sob clima Cwa de Köppen (mesotérmico, com pouco ou nenhum déficit hídrico e com grande excesso de precipitação no verão) (Moraes, 2001).

No total foram coletadas amostras de oito espécies de Leguminosae, três de Caesalpinioideae, três de Papilionoideae e duas de Mimosoideae. (Tabela 1).

A identificação dos materiais foi realizada pelos Drs. José Rubens Pirani e Waldir Mantovani, ambos pesquisadores do Instituto de Biociências da Universidade de São Paulo. Materiais testemunhos foram depositados no Herbário do Instituto de Biociências (SPF).

\section{Preparo do material botânico}

Frutos maduros foram coletados e mantidos à sombra até a abertura e obtenção das sementes. Estas foram armazenadas em freezer para posterior análise. Foram amostrados três indivíduos de cada espécie, com exceção de Crotalaria flavicoma Benth., da qual foi formado um "pool" de diversos indivíduos, devido ao seu pequeno porte e à baixa produção de sementes por indivíduo. 
Tabela 1. Espécimes de Leguminosae da Reserva Biológica de Mogi Guaçu, município de Mogi Guaçu (SP), dos quais se coletaram sementes para análises, datas e números de coletas. Espécimes-testemunhos estão depositados no Herbário do Departamento de Botânica, IB,

Universidade de São Paulo, SP (SPF)

\begin{tabular}{lll}
\hline $\begin{array}{l}\text { SUBFAMÍLIA } \\
\text { ESPÉCIE }\end{array}$ & VOUCHER & DATA \\
\hline Caesalpinioideae & & \\
Copaifera langsdorfii Desf. & Sasaki et al. 1 & $22 / 08 / 06$ \\
Dimorphandra mollis Benth. & Sasaki et al. 2 & $22 / 07 / 05$ \\
Hymenaea stigonocarpa Mart. ex Hayne & Egydio et al. 9 & $10 / 03 / 07$
\end{tabular}

\section{Papilionoideae}

Acosmium subelegans (Mohlenbr.)Yakovlev

Sasaki et al. $3 \quad$ 08/11/06

Andira laurifolia Benth.

Sasaki et al. 4 22/08/06

Crotalaria flavicoma Benth.

Sasaki et al. 5 28/03/06

\section{Mimosoideae}

Anadenanthera peregrina var. falcata (Benth.) Reis

Sasaki et al. $6 \quad$ 22/07/05

Inga uraguensis Hook. \& Arn.

Sasaki et al. 7 19/01/07 


\section{Doseamento de lipídios}

Todas as amostras foram analisadas com tegumento, exceto Inga uraguensis Hook. \& Arn. e Andira laurifolia Benth.

Amostras em triplicata contendo $1-5 \mathrm{~g}$ de sementes foram trituradas e homogeneizadas. As amostras foram envoltas em papéis de filtro previamente lavados com clorofórmio e tratadas com $n$-hexano em Soxhlet por $6 \mathrm{hs}$. O solvente foi eliminado sob vácuo e o óleo obtido mantido em dessecador, protegido da luz, até obtenção de peso constante (Ahmad et al., 1981). As amostras de óleo foram mantidas em freezer para a análise da composição de ácidos graxos.

\section{Identificação dos ácidos graxos}

Os ácidos graxos foram obtidos por meio de saponificação do óleo com 10 $\mathrm{mL}$ de solução metanólica de $\mathrm{KOH} 10 \%$ sob refluxo por duas horas. Após resfriamento, foi acrescentado igual volume de água e o material foi acidificado com $\mathrm{HCl} 10 \%$ até $\mathrm{pH} 4,0-5,0$. Os ácidos graxos foram extraídos três vezes com clorofórmio. Os extratos foram reunidos e o solvente removido sob pressão reduzida (Grunwald \& Endress, 1988).

Os ácidos graxos foram submetidos ao processo de metilação por meio de dissolução em éter sulfúrico e tratamento com cinco volumes de solução etérea de diazometano, obtida por hidrólise alcalina de $p$-toluil-sulfonil-metil-nitrosamina (Vogel, 1971). As soluções foram mantidas em banho de gelo por dez minutos e concentradas até a secura, sob fluxo de nitrogênio.

A análise dos ésteres metílicos de ácidos graxos foi efetuada por cromatografia em fase gasosa com detector de ionização de chama, injetando-se 1 $\mu \mathrm{L}$ de solução das amostras em éter etílico. Foi utilizado um cromatógrafo a gás Hewlett Packard 5890 série II Plus, provido de coluna capilar HP 20M (25 m x 0,32 $\mathrm{mm}$ ). Hélio foi usado como gás de arraste, fluxo de $1 \mathrm{~cm}^{3} / \mathrm{min}$. As temperaturas do injetor e detector foram $220^{\circ} \mathrm{C}$ e $245^{\circ} \mathrm{C}$, respectivamente. Foi usada a seguinte programação de temperaturas da coluna: $130^{\circ} \mathrm{C}$ por $2 \mathrm{~min}$, elevação de $5^{\circ} \mathrm{C} / \mathrm{min}$ até $230^{\circ} \mathrm{C}$, mantendo-se essa temperatura por $5 \mathrm{~min}$, elevação de $2^{\circ} \mathrm{C} / \mathrm{min}$ até $235^{\circ}$ C, mantendo-se nesse patamar por 10,5 min. A identificação dos ácidos graxos foi 
realizada por meio de análise por CG/EM, usando-se cromatógrafo a gás acoplado a espectrômetro de massas Shimadzu 14B/QP5050A, provido de coluna capilar DB-5 (30 m x 0,25 mm). Utilizaram-se as mesmas condições acima descritas para análise por cromatografia a gás, com energia de impacto de elétrons de $70 \mathrm{eV}$. A identificação dos componentes foi realizada por comparação entre os tempos de retenção correspondentes aos picos das amostras e os picos das substâncias de referência, e por comparação do espectro de massas correspondentes a cada pico com os espectros de massas das bibliotecas HP Wiley 229 e NIST.

\section{Doseamento de nitrogênio total}

O doseamento de nitrogênio total foi realizado pelo método micro-Kjeldahl (AOAC, 1995, modificado). Após a extração do óleo, $100 \mathrm{mg}$ da amostra desengordurada foram colocadas em tubo de ensaio, acrescentando-se $1 \mathrm{~g}$ de uma mistura de sulfato de sódio $(120 \mathrm{~g})$, sulfato de cobre $(20 \mathrm{~g})$ e selênio $(0,4 \mathrm{~g})$ e $5 \mathrm{~mL}$ de ácido sulfúrico. A digestão das amostras foi realizada em bloco digestor a $350^{\circ} \mathrm{C}$, até o material apresentar coloração esverdeada. Após a digestão, acrescentaram-se $15 \mathrm{~mL}$ de hidróxido de sódio $18 \mathrm{~N}$ e procedeu-se a destilação. $\mathrm{O}$ destilado foi coletado em erlenmeyer contendo $10 \mathrm{~mL}$ de ácido bórico $5 \%$ e a titulação foi realizada utilizando-se solução de ácido clorídrico 0,05 N. O teor de proteínas totais foi estimado utilizando o fator de 6,25. O cálculo do teor de proteínas obtido foi corrigido para incluir o teor de óleo ao peso das sementes.

\section{Doseamento de carboidratos solúveis}

Os açúcares solúveis totais foram extraídos utilizando-se $50 \mathrm{mg}$ das amostras desengorduradas. As amostras foram submetidas à extração com 1,5 mL de etanol $80 \%$ (v:v) durante 20 minutos a $80^{\circ} \mathrm{C}$. As amostras foram centrifugadas a 10000 rcf, à temperatura ambiente, por 10 minutos. Para a completa retirada dos açúcares solúveis, foram realizadas quatro extrações reunindo todos os sobrenadantes, constituindo a fração etanólica de cada amostra. Os resíduos foram lavados com 1,5 mL de água destilada e centrifugados nas mesmas condições por três vezes e por fim, liofilizados. Para a dosagem dos açúcares solúveis totais na 
fração etanólica foi utilizado o método do fenol-sulfúrico (Dubois et al., 1956), utilizando-se uma curva padrão com soluções aquosas de glucose nas concentrações de $5,10,20,30$ e $50 \mu \mathrm{g} / \mu \mathrm{L}$. Foram utilizadas alíquotas de $20 \mu \mathrm{L}$ para todas as espécies, exceto Inga uraguensis Hook. \& Arn., para a qual foram utilizados $80 \mu \mathrm{L}$ de uma amostra previamente tratada com clorofórmio e água (clorofórmio:água:amostra, nas proporções 1:4:1), para a retirada de pigmentos que pudessem interferir na leitura em espectrofotômetro. O cálculo do teor de açúcares solúveis totais obtido foi corrigido para incluir o teor de óleo ao peso das sementes.

\section{Doseamento de amido}

Para a determinação do teor de amido utilizou-se a metodologia proposta por Amaral e col. (2007). Foram utilizados $10 \mathrm{mg}$ do resíduo liofilizado, obtidos após extração dos açúcares solúveis totais. Ao material foi adicionado $0,5 \mathrm{~mL}(120 \mathrm{U} / \mathrm{mL})$ de $\alpha$-amilase termoestável de Bacillus licheniformis (MEGAZYME), diluída em tampão MOPS $10 \mathrm{mM} \mathrm{pH} \mathrm{6,5.} \mathrm{A} \mathrm{mistura} \mathrm{foi} \mathrm{incubada} \mathrm{a} 75^{\circ} \mathrm{C}$ por $30 \mathrm{~min}$. $\mathrm{O}$ procedimento foi repetido mais uma vez com $0,5 \mathrm{~mL}$ da enzima. Após resfriamento a $50^{\circ} \mathrm{C}$, adicionou-se $0,5 \mathrm{~mL}$ da solução contendo $30 \mathrm{U} / \mathrm{mL}$ de amiloglucosidase de Aspergillus niger (MEGAZYME) em tampão acetato de sódio $100 \mathrm{mM} \mathrm{pH} \mathrm{4,5} \mathrm{e} \mathrm{as}$ amostras foram incubadas a $50^{\circ} \mathrm{C}$ por $30 \mathrm{~min}$. $\mathrm{O}$ procedimento foi repetido mais uma vez totalizando $1,0 \mathrm{~mL}$ de enzima. Após essas incubações, foram acrescentados 100 $\mu \mathrm{L}$ de ácido perclórico $0,8 \mathrm{M}$ para interromper a reação e precipitar proteínas. Após rápida centrifugação (2 min a $10.000 \mathrm{~g}$ ), procedeu-se à dosagem em alíquotas de 50 $\mu \mathrm{l}$ de extrato, às quais foram adicionados $250 \mu \mathrm{L}$ das enzimas glucose oxidase e peroxidase e os reagentes 4-aminoantipirina e fenol (GODPOD - Glicose PAP Liquiform). Após incubação por $15 \mathrm{~min}$ a $37^{\circ} \mathrm{C}$, o teor de glucose foi determinado em leitor de micro placas de ELISA em comprimento de onda $490 \mathrm{~nm}$. A curva padrão foi realizada com solução de glucose $1 \mathrm{mg} / \mathrm{mL}$, nas concentrações de 1, 2, 5 e 7 $\mu \mathrm{g} / \mu \mathrm{L}$. O cálculo do teor de amido obtido foi corrigido para incluir o teor de óleo e dos carboidratos solúveis ao peso das sementes. 


\section{RESULTADOS E DISCUSSÃO}

\section{Lipídios}

Os cromatogramas obtidos na análise dos ésteres metílicos dos ácidos graxos estão apresentados na figura 3. A figura 4 apresenta o espectro de massas do éster metílico do ácido palmítico, ressaltando o pico do íon molecular, que corresponde ao peso molecular do composto e o pico base (pico mais intenso do espectro) (Silverstein \& Webster, 2000).

A Tabela 2 mostra os teores de lipídios das sementes de Leguminosae analisadas e respectivas composições em ácidos graxos. Os teores apresentados correspondem a médias de triplicatas de cada amostra, enquanto as porcentagens dos ácidos graxos correspondem a médias obtidas de duplicatas. Earle e Jones (1962) relataram que as leguminosas contêm baixo teor de lipídios, em média $5,5 \%$, e o resultado obtido no presente trabalho não foi diferente. A média de teor de lipídios encontrada foi de 5,09\%, entretanto, as sementes de Acosmium subelegans apresentaram teor relativamente alto $(13,14 \%)$. Mayworm e Salatino (1996a), estudando a mesma espécie, obtiveram teor semelhante $(11,6 \%)$.

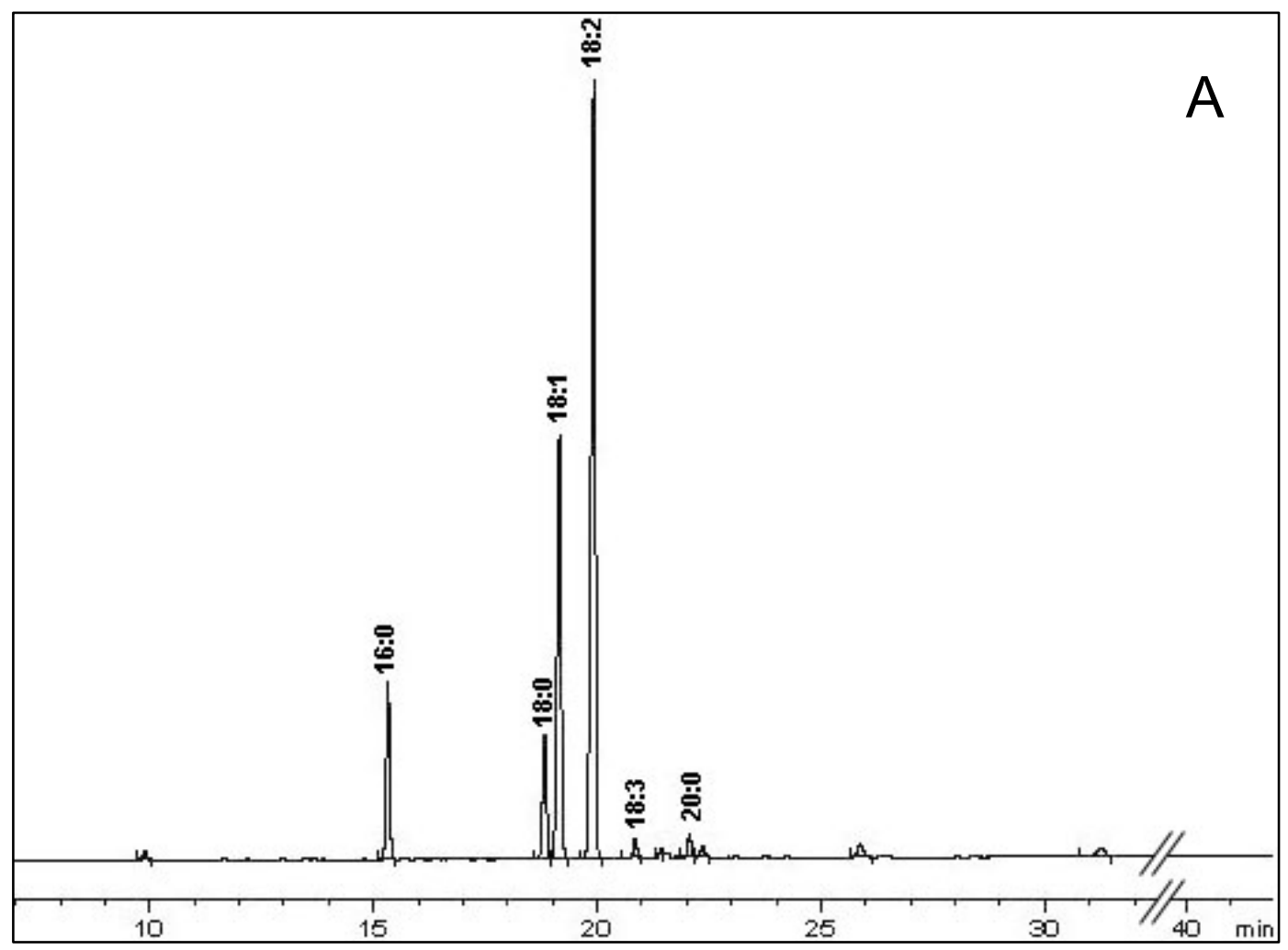



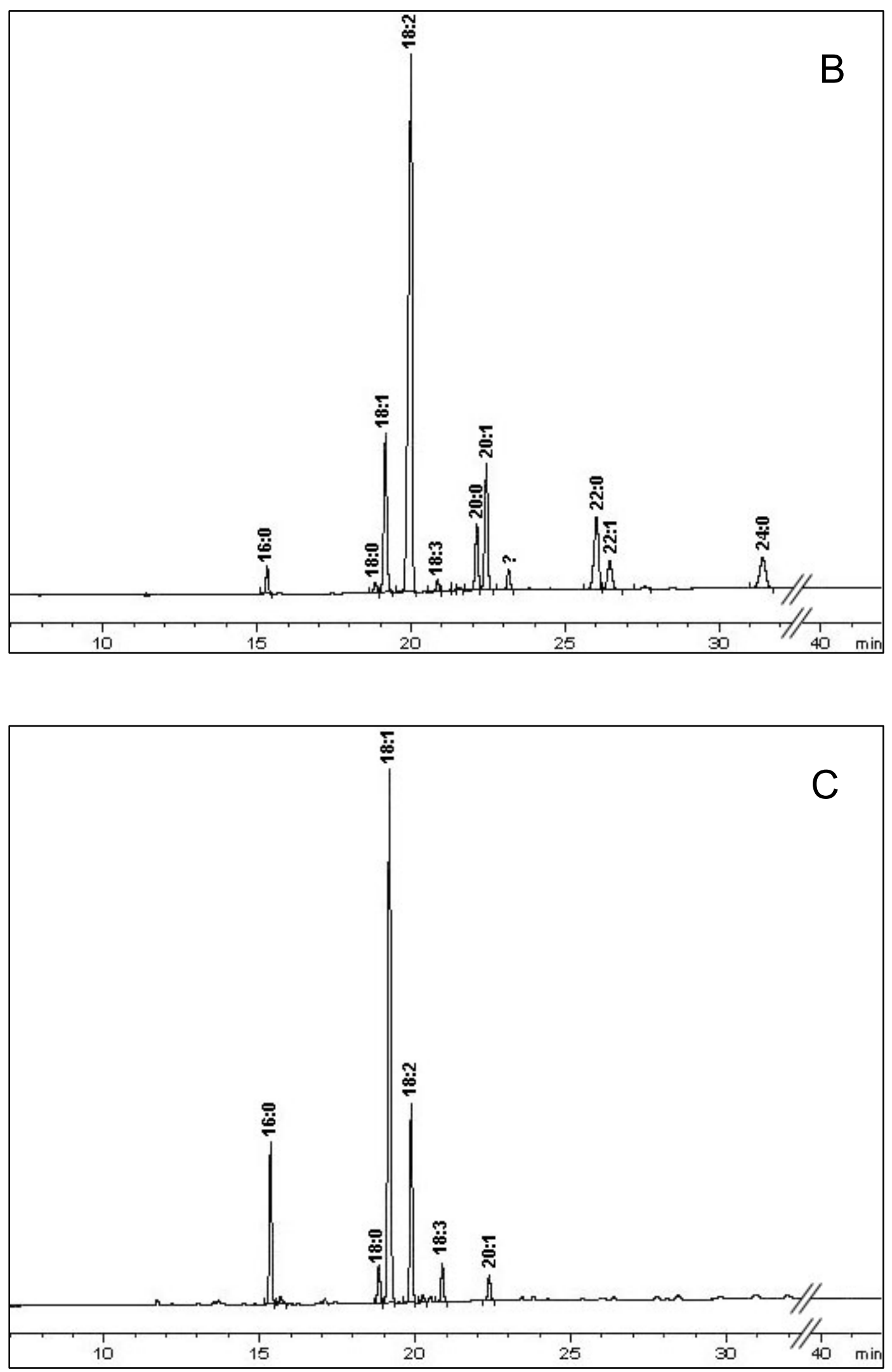

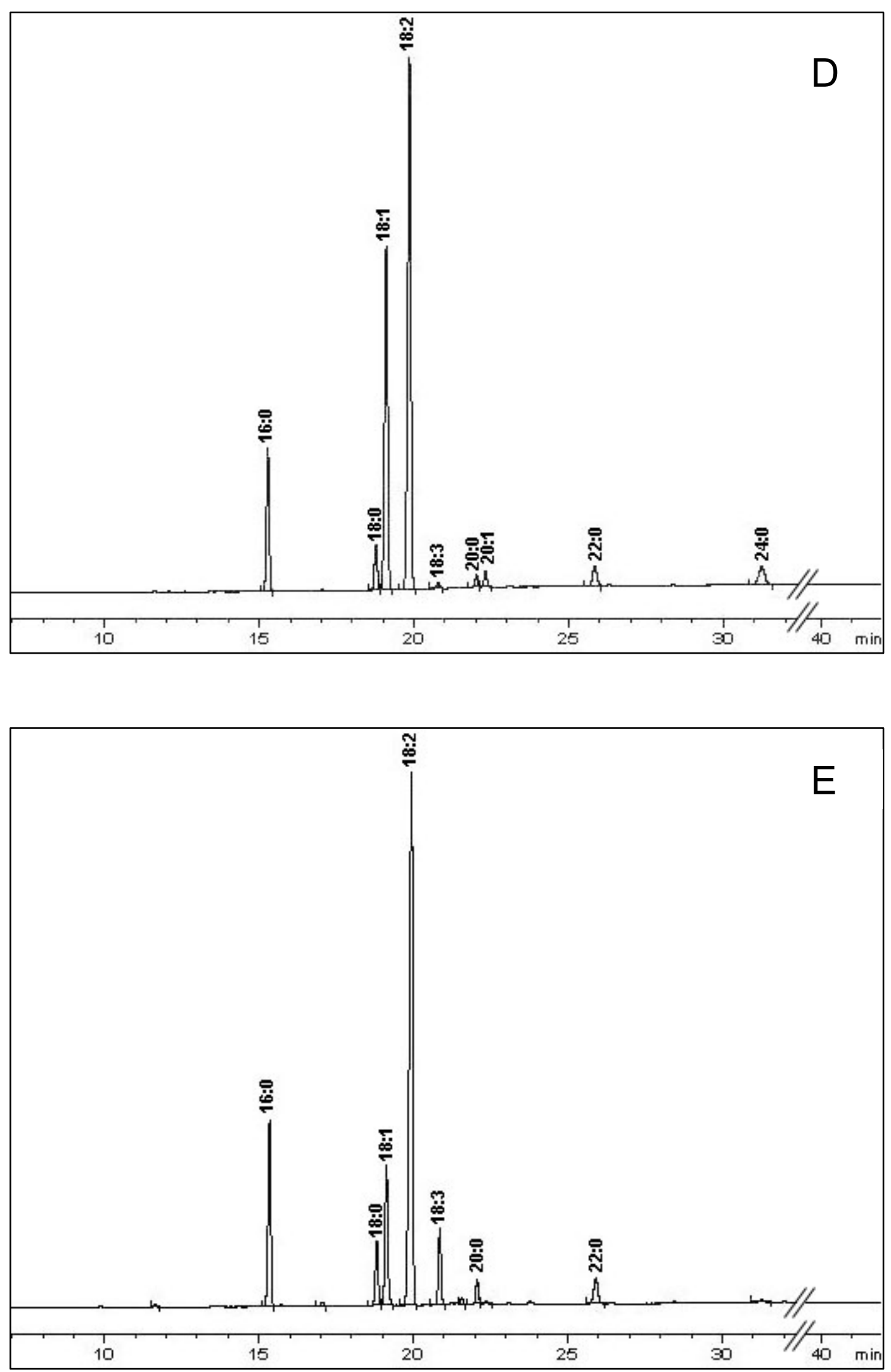

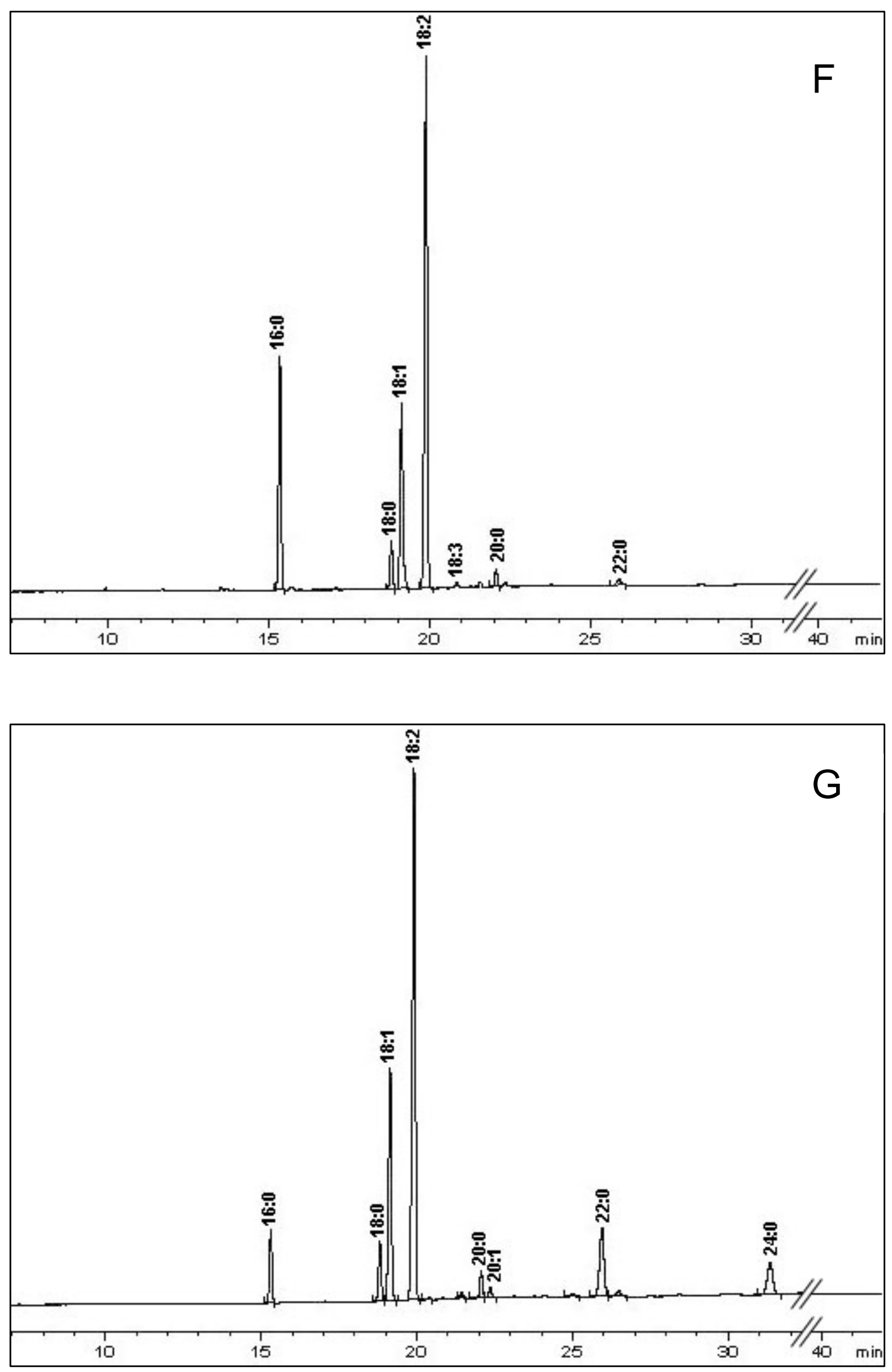


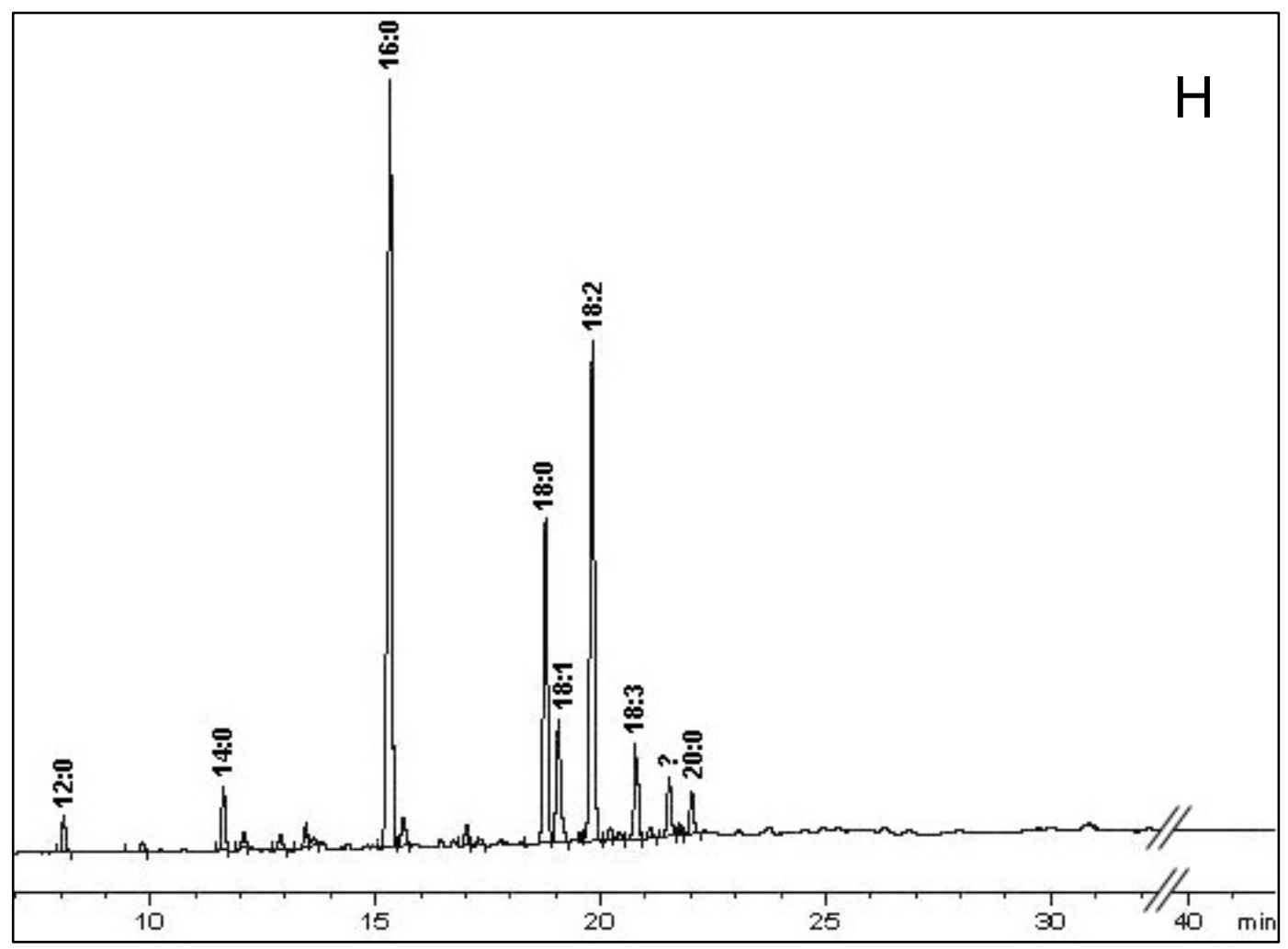

Figura 3. Cromatogramas de análises por cromatografia em fase gasosa de ácidos graxos de lipídios de sementes de leguminosas do cerrado. A: Acosmium subelegans; B: Anadenanthera peregrina var. falcata; C: Andira laurifolia; D: Copaifera langsdorfii; E: Crotalaria flavicoma; F: Dimorphandra mollis; G: Hymenaea stigonocarpa; $\mathrm{H}$ : Inga uraguensis

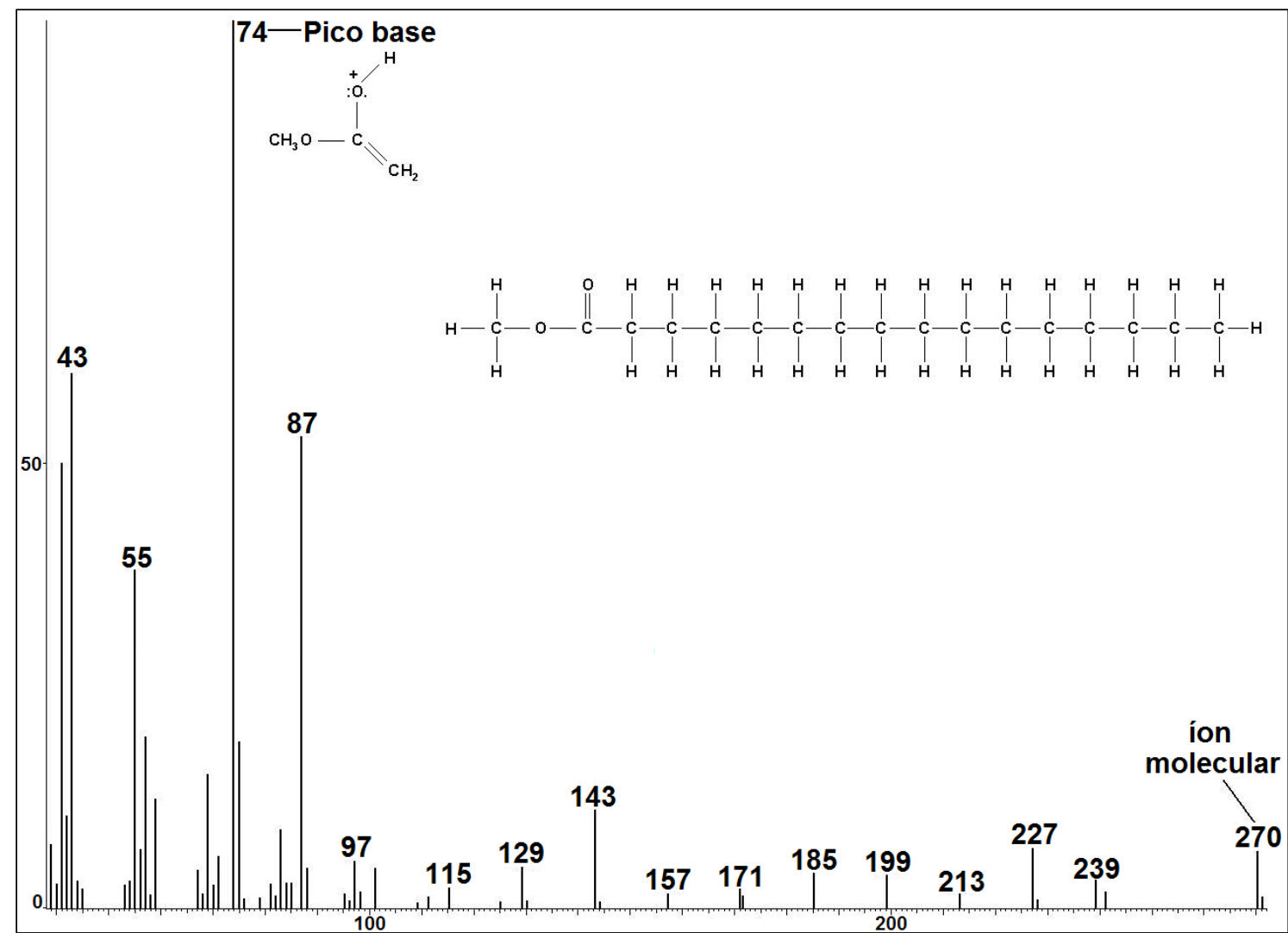

Figura 4. Espectro de massas do éster metílico de ácido palmítico, sua estrutura molecular e estrutura molecular do íon do pico base. 
Tabela 2. Teores percentuais de óleo e abundância relativa (\%) dos ácidos graxos de sementes de espécies de Leguminosae do cerrado

\begin{tabular}{|c|c|c|c|c|c|c|c|c|c|c|c|c|c|c|c|}
\hline \multirow{2}{*}{ ESPÉCIE } & \multirow{2}{*}{ Óleo } & \multicolumn{12}{|c|}{ Distribuição de ácidos graxos } & \multirow[b]{2}{*}{ sat } & \multirow[b]{2}{*}{ insat } \\
\hline & & $12: 0$ & $14: 0$ & 16:0 & 18:0 & $18: 1$ & $18: 2$ & $18: 3$ & $20: 0$ & $20: 1$ & $22: 0$ & $22: 1$ & $24: 0$ & & \\
\hline Acosmium subelegans & $13,14 \pm 1,97$ & - & - & 17,5 & 14,5 & 26,6 & 39,7 & 0,3 & 1,4 & $\operatorname{tr}$ & $\operatorname{tr}$ & - & $\operatorname{tr}$ & 33,4 & 66,6 \\
\hline $\begin{array}{l}\text { Anadenanthera peregrina var. } \\
\text { falcata }\end{array}$ & $6,97 \pm 0,75$ & - & - & 5,6 & 0,8 & 13,1 & 43,1 & 0,4 & 8,5 & 7,9 & 12,3 & 1,8 & 6,5 & 33,8 & 66,2 \\
\hline Andira laurifolia & $0,54 \pm 0,12$ & - & - & 30,4 & 6,2 & 41,5 & 17,6 & 3,6 & - & 0,7 & - & - & - & 36,6 & 63,4 \\
\hline Copaifera langsdorfii & $7,23 \pm 0,37$ & - & - & 20,3 & 7,1 & 22,8 & 37,5 & 0,2 & 1,7 & 1,1 & 4,2 & - & 5,1 & 38,3 & 61,7 \\
\hline Crotalaria flavicoma & $3,29 \pm 0,04$ & - & - & 26,8 & 10,0 & 9,1 & 40,0 & 4,4 & 3,6 & $\operatorname{tr}$ & 6,2 & - & - & 46,5 & 53,5 \\
\hline Dimorphandra mollis & $1,91 \pm 0,15$ & - & - & 36,7 & 7,2 & 13,0 & 39,8 & 0,3 & 2,3 & - & 0,7 & - & - & 46,9 & 53,1 \\
\hline Hymenaea stigonocarpa & $7,41 \pm 0,32$ & - & - & 10,0 & 9,8 & 18,5 & 38,0 & $\operatorname{tr}$ & 3,5 & 0,4 & 12,6 & $\operatorname{tr}$ & 6,9 & 43,0 & 57,0 \\
\hline Inga uraguensis & $0,24 \pm 0,06$ & 5,8 & 8,7 & 47,3 & 18,4 & 3,3 & 12,2 & 2,8 & 1,6 & - & - & - & - & 81,8 & 18,2 \\
\hline
\end{tabular}

(-) não detectado

(tr) $<0,01 \%$

(sat) total de ácidos graxos saturados

(insat) total de ácidos graxos insaturados 
Mayworm e Salatino (1996a) ainda encontraram para as espécies Dimorphandra mollis e Anadenanthera peregrina var. falcata, respectivamente 2 e $2,1 \%$ de lipídios. Essas duas espécies também foram estudadas no presente trabalho e o resultado para D.mollis foi próximo (1,91\%), porém, para Anadenanthera peregrina var. falcata o teor de óleo obtido foi mais de três vezes superior $(6,97 \%)$. Panegassi e col. (2001) também obtiveram valor muito superior de lipídios em D.mollis (7\%) e Mayworm e Salatino (1996b) analisando sementes de Anadenanthera colubrina, obtiveram teor de 3,1\%. Crotalaria flavicoma apresentou $3,29 \%$ de óleo, que está em concordância com os trabalhos de Earle e Jones (1962) e Jones e Earle (1966), que juntos, analisaram 13 espécies de Crotalaria, obtendo também uma média de 3,3\% para o gênero. Já Hosamani e Ramesh (2001) encontraram teor de $5 \%$ em Crotalaria striata e um valor bem superior $(9,2 \%)$ foi relatado para Crotalaria anagyroides (Maestri et al., 2002). Copaifera langsdorfii apresentou $7,23 \%$, valor similar ao encontrado por Façanha e Varela (1986/1987) em Copaifera multijuga (6,1\%), ambos superiores aos valores obtidos em Copaifera officinalis (2,4\%) por Veiga Junior e col. (2007). O rendimento de lipídios em Hymenaea stigonocarpa foi de 7,41\%, superior ao obtido por Matuda e Netto (2005), de um indivíduo coletado no Piauí (5,3\%) e inferior ao de Hymenaea courbaril do México (8,6\%) (Sotelo, 1996 apud Matuda e Netto, 2005). Os rendimentos obtidos para Andira laurifolia e Inga uraguensis foram extremamente baixos (0,54 e 0,24\%, nesta ordem). Handro (1968) realizou testes com Sudan IV (para detecção de lipídios) e tentou extrair óleo dos cotilédones de Andira humilis e verificou a ausência desse componente. Mello (comunicação pessoal)*, também encontrou teores muito baixos de lipídios em Inga vera (0,2-0,6\%). Os constituintes das sementes são determinados geneticamente, mas a quantidade relativa destes constituintes às vezes é dependente de fatores ambientais, tais como nutrição mineral e clima (Mayer \& Poljakoff-Mayber, 1975). Variações também podem ser atribuídas a vários outros fatores: a) fases distintas de maturação das sementes; b) diferenças de teores entre populações; c) diferenças entre épocas distintas de coleta; d) problemas de identificação das amostras. No momento, não é possível optar por um ou outro fator que explique as diferenças apontadas.

\footnotetext{
* Mello, J.I.O. 2008. Comunicação pessoal.
} 
No total, foram identificados 17 ácidos graxos, mas apenas 12 estão representados na tabela 2. Os demais só foram encontrados em quantidades traço em uma única espécie: ácido tridecanóico (C13:0) em Anadenanthera peregrina var. falcata, ácidos pentadecanóico (C15:0), palmitoléico (16:1) e heptadecanóico (C17:0) em Inga uraguensis, o último também em Crotalaria flavicoma e ácido haxecosanóico (C26:0) em Hymenaea stigonocarpa. Dois picos não puderam ser identificados: em Inga uraguensis, com tempo de retenção intermediário entre os ácidos linolênico (18:3) e araquídico (20:0) (Figura 3H) e em Anadenanthera peregrina var. falcata, com tempo de retenção intermediário entre os ácidos eicosanóico (20:1) e behênico (22:0) (Figura 3B).

Os ácidos saturados láurico (C12:0) e mirístico (C14:0) só foram observados nas sementes de Inga uraguensis, com 5,8 e 8,7\%, respectivamente (Tabela 2). Entretanto, Mello (comunicação pessoal) ${ }^{*}$ não encontrou esses ácidos graxos de cadeia curta em Inga vera. Inversamente, essa autora obteve ácidos graxos saturados de cadeia longa, como os ácidos araquídico (20:0), behênico (22:0) e lignocérico (24:0). Dentre os ácidos graxos saturados, em média, o mais predominante foi o ácido palmítico (C16:0), exceto em Hymenaea stigonocarpa (Figura 3G) e Anadenanthera peregrina var. falcata (Figura 3B), nas quais houve predominância do ácido behênico (C22:0), seguido do ácido esteárico (C18:0) (Tabela 2). Esse resultado é coerente com o fato de que o ácido palmítico é o ácido graxo saturado mais abundante nos seres vivos, não só nos lipídios vegetais, mas também em óleos de peixes e gorduras animais, sendo o ácido esteárico muito menos comum (Gunstone, 1996). Entretanto, em vários trabalhos (Hosamani, 1995; Lamarque et al., 2000b; Hosamani \& Sattigeri, 2002; Maestri et al.,2002; Mazzuca \& Balzaretti, 2003; Bagci et al., 2004; Mayworm et al., 2004) e nos levantamentos bibliográficos feitos por Wolff \& Kwolek (1971) e Mayworm (1994) observa-se que a proporção dos ácidos palmítico e esteárico varia (com algumas exceções) em torno de $5-20 \%$ e $4-6,5 \%$, respectivamente e, no presente estudo, foram encontradas médias mais altas, tanto para o ácido palmítico $(5,6-47,3 \%)$ como para o ácido esteárico $(0,8-18,4 \%)$. É interessante citar que alguns autores encontraram em leguminosas maior proporção de ácido esteárico do que palmítico. Katiyar e Bhatia (1986) encontraram $25,4 \%$ de ácido esteárico e ausência de ácido palmítico em

\footnotetext{
* Mello, J.I.O. 2008. Comunicação pessoal.
} 
Cicer soongaicum e, mais recentemente, Saxena e Mishra (2003) relataram 18,2\% de ácido esteárico e 9,8\% de palmítico em Sesbania aegyptiaca. Muitos óleos de sementes de leguminosas caracteristicamente contêm substanciais quantidades de ácidos graxos saturados, especialmente com cadeias longas (20, 22 e 24 átomos de carbono), com média geral (combinando os três ácidos) de 4,0\% (Wolff \& Kwolek, 1971). Os resultados relativos às espécies analisadas (Tabela 2) variaram de zero (Andira laurifolia) a $29,1 \%$ (Anadenanthera peregrina var. falcata). Valores compatíveis a esses foram encontrados por Adewusi e col. (2003), que analisaram sementes de Acacia tumida e obtiveram 10,8\% dos mesmos ácidos saturados de cadeia longa. Balogun e Fetuga (1985) e Akpinar e col. (2001) relataram que óleos com alto teor de ácido behênico (C22:0) podem ser de difícil digestão para humanos e animais e sua presença pode ter sérias implicações para utilização nutricional. Com isso em mente, deve ser ressaltada a presença desse ácido em mais de $1 \%$ em cinco espécies e dentre estas, duas (Hymenaea stigonocarpa e Anadenanthera peregrina var. falcata) apresentaram mais de $12 \%$. Matuda e Netto (2005) também analisaram sementes de Hymenaea stigonocarpa, mas relataram a presença de traços de ácidos de cadeia longa, que não foram identificados. Da mesma forma que Mayworm e Salatino (1996b) encontraram apenas 1,5\% de ácido behênico em Anadenanthera colubrina. Assim como relatado por Bagci e col. (2004), o total de ácidos graxos saturados não mostrou muita variação entre os gêneros, exceto Inga uraguensis, com uma porcentagem muito maior desses ácidos $(81,8 \%)$. Entretanto, os valores encontrados para todas as outras espécies foram superiores (33-47\%, mesmo sem incluir o ingá) aos de Bagci e col. (2004) e de Asilbekova (2004), cujas médias variaram de 15 a $20 \%$.

Dentre os insaturados, o ácido linoléico (C18:2) foi o predominante, seguido do oléico (C18:1) (Tabela 2). Isso corrobora os dados da literatura, pois os principais componentes insaturados dentro de Leguminosae são esses dois ácidos. Diversos autores relatam que, juntos, esses ácidos constituem $62-80 \%$ do total de ácidos graxos de sementes de leguminosas (Wolff \& Kwolek, 1971; Sengupta \& Basu, 1978; Hilditch \& Williams, 1964 apud Balogun \& Fetuga, 1985). Nas espécies analisadas neste trabalho a média foi menor $(51,5 \%)$ e o teor relatado por Mayworm e Salatino (1996a) é ainda mais baixo (42,7\%). Das espécies analisadas, as duas com maiores teores de ácidos oléico e linoléico foram Acosmium subelegans (66,3\%) e Copaifera langsdorfii (60,3\%). Uma espécie de Copaifera foi estudada por Maia e col. (1978) e 
apresentou porcentagem superior $(70 \%)$, com maior proporção de ácido oléico. As demais proporções não divergem muito, exceto pelo ácido esteárico, que não foi encontrado por esses autores, mas no presente trabalho obteve-se média de $7,1 \%$. $\mathrm{O}$ ácido linoléico como o ácido principal é coerente com o fato de que em apenas cerca de $20 \%$ das leguminosas analisadas até o presente o ácido oléico predomina e nas demais $80 \%$ o ácido predominante é o linoléico. Foram detectados apenas traços de ácido linolênico em Hymenaea stigonocarpa e nas demais espécies, a média total foi relativamente baixa $(0,2-4,4 \%$ ) (Tabela 2), o que está de acordo com Hilditch e Williams (1964 apud Wolff \& Kwolek, 1971), que reportaram que tal ácido varia de zero até $20-35 \%$ do total de ácido graxos. A presença desse ácido (junto com outros ácidos poliinsaturados) torna o óleo menos estável, mas ele é um ácido graxo essencial e o óleo de soja, por exemplo, apresenta médias superiores (5,5$9,5 \%$ ) (Wang, 2002) às obtidas no presente trabalho.

Apenas uma espécie (Andira laurifolia) apresentou predominância do ácido oléico em relação ao linoléico (Figura $3 \mathrm{C}$ ). Essa espécie é incomum também em relação a seus frutos, que não são legumes, mas sim drupas carnosas (Pennington et al., 2000). Segundo Handro (1968), em Andira humilis o óleo se concentra no mesocarpo do fruto e não nos cotilédones. Esse autor analisou a composição de ácidos graxos do fruto e observou predominância do ácido oléico, porém a proporção desse ácido no fruto $(65,9-75,1 \%)$ é distinta da observada no óleo das sementes de Andira laurifolia (41,5\%). Além disso, nas sementes foram encontradas maiores porcentagens de ácido palmítico $(30,4 \%)$, esteárico $(6,2 \%)$ e linoléico $(17,6 \%)$ (Tabela 2), quando comparados com as porcentagens obtidas nos frutos por Handro (1968), que foram de 7,0-10,9\%, 1,1-3,4\% e 2,1-6,1\%, respectivamente. Uma observação interessante é a alta proporção de ácido linolênico nos frutos (7,5$16,0 \%$ ), em comparação aos 3,6\% das sementes. Segundo Pokorný (2006), os óleos de sementes possuem composição de ácidos graxos diferente dos óleos de pericarpos, entretanto, Egydio (2004) encontrou uma composição de ácidos graxos nas sementes de acerola semelhantes aos descritos na literatura para os frutos.

Dados da literatura (Wolff \& Kwolek, 1971; Sengupta \& Basu, 1978; Hilditch \& Williams, 1964 apud Balogun \& Fetuga, 1985; Hosamani, 1995; Lamarque et al., 2000a; Hossain \& Becker, 2001; Mazzuca \& Balzaretti, 2003; Asilbekova, 2004; Bagci et al., 2004; Mayworm et al., 2004; Asilbekova et al., 2005; Matuda \& Netto, 2005) sugerem que nas leguminosas em geral há o predomínio de ácido linoléico, 
seguido por oléico e palmítico. Mayworm (1994) e Mayworm e Salatino (1996a) relataram o predomínio sistemático de ácido palmítico em espécies do cerrado na família $(38,9 \%)$ e quantidades inferiores de ácido linoléico. Entretanto, nas espécies de cerrado analisadas foi observado, na média para a família, o predomínio do ácido linoléico $(33,3 \%)$, como era esperado, mas seguido pelo ácido palmítico $(24,6 \%)$ e oléico (18,2\%). Essa mesma ordem foi encontrada por Hosamani e Sattigeri (2002) em espécies de Cassia, porém com diferenças mais sutis entre os ácidos palmítico $(17,2 \%)$ e oléico $(14,5 \%)$. De fato, apenas uma espécie, Dimorphandra mollis (Figura 3F) apresentou essa ordem. Crotalaria flavicoma (Figura 3E) teve como terceiro ácido mais predominante o esteárico (ao invés do oléico), Copaifera langsdorfii (Figura 3D) e Acosmium subelegans (Figura 3A) mostraram a ordem comum às leguminosas e Hymenaea stigonocarpa (Figura 3G) e Anadenanthera peregrina var. falcata (Figura 3B) tiveram o ácido linoléico, seguido do oléico e (estranhamente) behênico (Tabela 2). Em Andira laurifolia (Figura 3C) o ácido oléico foi o principal, seguido por palmítico e linoléico, e em Inga uraguensis (Figura $3 \mathrm{H}$ ) o predominante foi o palmítico, depois o esteárico e o linoléico, diferentemente do obtido em Inga vera por Mello (comunicação pessoal)*, cuja ordem foi palmítico, esteárico e lignocérico. Contrastando com todos esses resultados, Hosamani e Ramesh (2001) analisaram sementes de Crotalaria striata e encontraram o ácido palmítico como o predominante $(32,1 \%)$, seguido pelos ácidos ricinoléico $(15,8 \%)$, linoléico e linolênico, ambos com 15\%, e o ácido oléico com apenas $8 \%$.

O ácido erúcico (C22:1) causa efeitos indesejáveis no metabolismo animal e humano (James, 1994). Foi detectado no presente trabalho apenas nas sementes de Anadenanthera peregrina var. falcata (1,8\%) (Figura 3B, Tabela 2).

O padrão geral apresentado pelas sementes de leguminosas é a predominância de ácidos graxos insaturados, principalmente linoléico e oléico. Mayworm (1994) e Mayworm e Salatino (1996a) relataram o predomínio sistemático de ácido palmítico nas sementes dessa família e sugeriram que as sementes de muitas espécies de cerrado tendem a apresentar óleos com nível relativamente baixo de insaturação dos ácidos graxos. No presente trabalho foi observada a predominância dos ácidos graxos insaturados (Tabela 2), porém com maior proporção de ácidos palmítico e esteárico, quando comparados com espécies de

\footnotetext{
* Mello, J.I.O. 2008. Comunicação pessoal.
} 
leguminosas não pertencentes ao cerrado, sugerindo a tendência a uma maior proporção de ácidos graxos saturados em espécies de leguminosas do cerrado.

\section{Carboidratos}

O rendimento de açúcares solúveis totais (Tabela 3) variou de 5,91\% (Copaifera langsdorfii) a 10,16\% (Acosmium subelegans), valores que estão em concordância com Sosulski e Sosulski (2006), que afirmam que leguminosas, em geral, contêm significantes concentrações de açúcares livres (4-10\%). A única exceção foi Inga uraguensis, que apresentou 39,89\%. Porém observou-se que o teor de umidade nessa espécie é superior a $60 \%$, o que faria o teor de açúcares solúveis totais, em peso seco, decair para aproximadamente 12\%. Apesar das metodologias serem algumas vezes diferentes, os rendimentos encontrados por diversos autores estão nessa mesma faixa (Rao \& Belavady, 1978; Sosulski et al., 1982; Reddy et al., 1984; Kuo et al., 1988; Horbowicz et al., 1995; Sánchez-Mata et al., 1998). Excluindo Inga uraguensis, a média para a família foi de 7,92\%, similar à média relatada por Naivikul e D’Appolonia (1978) para diversas leguminosas (4,99-7,22\%). Inga uraguensis apresentou teor maior (aproximadamente 12\%, em peso seco), resultado próximo aos de Adewusi e col. (2003), que relataram 12,4\% para Acacia colei e $14,6 \%$ para Acacia tumida. Valores mais baixos também podem ser encontrados, como em sementes de espécies de Mucuna (2\%, em média) estudadas por Ezeagu e col. (2003). Entretanto, Steadman e col. (1996) analisaram sementes de quatro espécies de Inga e obtiveram médias muito inferiores (2-6\%). Nessa metodologia de quantificação de açúcares estão incluídos os valores de monossacarídeos e oligossacarídeos, que não foram analisados separadamente. Alguns oligossacarídeos (da série rafinósica) podem ter um efeito benéfico na saúde humana pelo aumento na população de bifidobactérias no cólon (Bouhnik et al., 2004), entretanto, eles são responsáveis pela flatulência causada pelo consumo de grandes quantidades de sementes de leguminosas (Vidal-Valverde et al., 1993). Por comporem aproximadamente $60 \%$ dos açúcares solúveis das leguminosas (Sosulski \& Sosulski, 2006) e 5-15\% do peso seco da semente (Cochrane, 2000), esses oligossacarídeos representam um sério problema nutricional, sendo uma das maiores limitações para o uso na alimentação. Felizmente, tratamentos simples 
reduzem seu teor, como "deixar de molho" (Vidal-Valverde et al., 2002; Urbano et al., 2005) e cozinhar (Frias et al., 2000). A fermentação também tem o mesmo efeito (Achinewhu, 1986; Egounlety \& Aworh, 2003) e a germinação pode diminuir o teor desses oligossacarídeos, além de aumentar o teor de mono- e outros oligossacarídeos, contribuindo para um aumento no valor nutricional das sementes (Rao \& Belavady, 1978; Martín-Cabrejas et al., 2008). Apesar da constante presença desses açúcares em sementes de leguminosas, em espécies de Inga analisadas por Steadman e col. (1996), não foram encontrados rafinose nem estaquiose.

Tabela 3: Teores percentuais de açúcares solúveis totais, amido e proteína de sementes de espécies de Leguminosae do cerrado

\begin{tabular}{lccc}
\hline ESPÉCIE & Açúcar & Amido & Proteína \\
\hline Acosmium subelegans & $10,16 \pm 0,74$ & $0,22 \pm 0,02$ & $28,34 \pm 2,01$ \\
Anadenanthera peregrina var. falcata & $8,73 \pm 1,39$ & $0,45 \pm 0,06$ & $30,35 \pm 0,70$ \\
Andira laurifolia & $6,34 \pm 1,10$ & $56,27 \pm 0,61$ & $11,85 \pm 0,51$ \\
Copaifera langsdorfii & $5,91 \pm 0,61$ & $0,18 \pm 0,03$ & $10,48 \pm 1,22$ \\
Crotalaria flavicoma & $8,31 \pm 0,74$ & $0,18 \pm 0,03$ & $25,00 \pm 1,35$ \\
Dimorphandra mollis & $6,31 \pm 0,70$ & $0,11 \pm 0,06$ & $15,00 \pm 3,09$ \\
Hymenaea stigonocarpa & $9,65 \pm 0,78$ & $0,19 \pm 0,02$ & $9,05 \pm 0,04$ \\
Inga uraguensis & $39,89 \pm 4,02$ & $17,86 \pm 2,31$ & $13,23 \pm 0,48$
\end{tabular}

Em relação ao amido, excluindo Andira laurifolia (56,27\%) e Inga uraguensis $(17,86 \%)$, em geral os teores foram baixos (Tabela 3 ), variando de $0,11 \%$ (Dimorphandra mollis) a $0,45 \%$ (Anadenanthera peregrina var. falcata). Como as sementes de Andira laurifolia e Inga uraguensis têm teores de umidade superiores a $60 \%$ (dados inéditos), em peso seco, os teores de amido seriam ainda mais baixos. Apesar de o amido ser o carboidrato de reserva de semente mais abundante e representar o principal constituinte do material de reserva de muitas espécies (Ziegler, 1995), Kooiman (1960, 1963 apud Bailey, 1971) amostrou 94-230 gêneros de Leguminosae e a maioria das sementes se revelou desprovida de amido. Tookey e Jones (1965) não encontraram amido em nenhuma das 173 espécies de leguminosas analisadas. Earle e Jones (1962) e Jones e Earle (1966) obtiveram 
resultado positivo para apenas $20 \%$ das espécies investigadas Comumente, 27 gêneros de leguminosas apresentam amido (Bailey, 1971), dentre esses Ingá. Handro (1968) observou que em Andira humilis o parênquima dos cotilédones estava totalmente preenchido com grãos de amido. Dessa forma, encontrar amido em Inga uraguensis e Andira laurifolia seria provável. Wolff e Kwolek (1971) concluíram que, com algumas exceções, as sementes de leguminosas com baixo teor de óleo (abaixo de 2,7\%), mais provavelmente contêm amido. Coerentemente, essas duas espécies foram as que apresentaram menos de $1 \%$ de lipídio (Tabela 2). Altos teores de amido foram encontrados por Ezeagu e col. (2003) em espécies de Mucuna (36,59\%, em média) e por Saikia e col. (1999) em diferentes cultivares de Vigna umbellata (48,13\%), gêneros esses também citados por Bailey (1971) como portadores de amido.

Dentre as espécies que apresentaram baixos teores de amido, muitas apresentam polissacarídeos de parede em grandes quantidades. Dimorphandra mollis apresenta mais de $40 \%$ de galactomananos (Buckeridge \& Dietrich, 1990; Buckeridge et al., 1995a) e espécies de Crotalaria, em média, 17\% (Wolff \& Kwolek, 1971; Buckeridge et al., 2000a). Wolff e Kwolek (1971) ainda sugeriram que sementes de leguminosas com altas porcentagens de galactomananos provavelmente têm baixo teor de óleo e as espécies com menores teores de lipídios foram justamente Dimorphandra mollis e Crotalaria flavicoma (Tabela 2). Analisando outro polissacarídeo de parede celular, Buckeridge e Dietrich (1990) obtiveram xiloglucanos em Copaifera langsdorfii (29,3\%) e Hymenaea sp. (32,7\%). Esses autores ainda encontraram baixos teores de galactanos (4,1\%) em Acosmium dasycarpum. Em Anadenanthera peregrina var. falcata e Inga uraguensis não foram observados galactomananos (Buckeridge et al., 1995b).

\section{Proteínas}

A porcentagem de nitrogênio total foi convertida em teor de proteína, multiplicando-se pelo fator 6,25 , que é utilizado quando o fator de multiplicação não é conhecido, baseado no fato de que a maioria das proteínas contém ao redor de $16 \%$ de nitrogênio (Sgarbieri, 1996). O uso desse fator é motivo de polêmica, devido a variações entre alimentos (Sosulski \& Imafidon, 1990; Salo-Väänanem \& 
Koivistoinen, 1996) e entre espécies (Mossé, 1990). No entanto, não existe um consenso de qual deveria ser um valor para uso geral. Recentemente, Ezeagu e col. (2002) sugeriram o fator 4,97 para leguminosas, mas o estudo foi realizado com apenas dez espécies. Apesar das críticas, o fator 6,25 ainda é o mais utilizado na literatura e endossado pela AOAC (Association of Official Analytical Chemists) (AOAC, 1995) e pelo Código Federal de Regulamentações Americano (EUA, 2007).

Os teores de proteínas encontrados no presente trabalho situam-se entre 9$30 \%$ das sementes (Tabela 3). O menor valor (9,05\%) corresponde a Hymenaea stigonocarpa, valor semelhante ao obtido por Matuda e Netto (2005) (9,75\%, valor recalculado com fator 6,25). Entretanto, em peso seco, as espécies com menores valores seriam Andira laurifolia e Inga uraguensis, respectivamente com $6,30 \%$ e 4,28\%. De acordo com Jones e Earle (1966), há uma tendência nas leguminosas de as sementes providas de amido apresentarem pouco teor de óleo e proteína. Concordando com essa sugestão, essas duas espécies foram as únicas que apresentaram quantidades consideráveis de amido (Tabela 3) e também os menores teores de lipídios (Tabela 2). Dimorphandra mollis apresentou $15 \%$ de proteína, valor semelhante ao encontrado por Panegassi e col. (2001) (16,8\%). As espécies com maiores teores foram Crotalaria flavicoma (25\%), Acosmium subelegans $(28,34 \%)$ e Anadenanthera peregrina var. falcata (30,35\%). Diversas espécies de Crotalaria já foram investigadas (Earle \& Jones, 1962; Jones \& Earle, 1966; Pandey \& Srivastava, 1990) e foram obtidos valores de 24,2 a $41,1 \%$ de proteínas, estando Crotalaria flavicoma dentro desse intervalo. Embora Morris e Kays (2005) tenham obtido teores entre 44 e 49\% em alguns genótipos de C.juncea. Essas três espécies possuem teores similares e até superiores a de algumas das leguminosas mais utilizadas na alimentação, como feijão comum e lentilha (ambos 24\%), ervilha (20\%), amendoim (28\%), embora seja inferior à soja (39\%) (Sosulski \& Sosulski, 2006). O teor de proteína calculado por meio do fator 6,25 pode ser superestimado pelo fato de uma boa porcentagem do total de nitrogênio ser de origem não protéica, incluindo alcalóides, clorofila, alguns glicosídeos, aminoácidos livres ou não protéicos, entre outros compostos (Ezeagu et al., 2002). Em espécies de Crotalaria é comum a presença de alcalóides pirrolizidínicos (Mears \& Mabry, 1971; Wink \& Mohamed, 2003), em Anadenanthera peregrina e A. colubrina são encontrados alcalóides indólicos, substâncias psicoativas utilizadas em rituais desde a era pré-hispânica (Angelo \& Capriles, 2004), como a bufotenina (Schultes, 1970; De Smet, 1985). 
Kinghorn e Smolenski (1981) relataram a presença de um alcalóide quinolizidínico pentacíclico em Acosmium subelegans. Provavelmente, sementes de espécies de Acosmium são fontes comuns de alcalóides quinolizidínicos. A filogenia molecular sugere que o gênero inclui-se na aliança genistóide de Sophoreae, ao lado de Ormosia, outro gênero lenhoso tropical reconhecido como abundante fonte de alcalóides quinolizidínicos (Wyk, 2003). De fato, sementes de Acosmium panamense contêm alcalóides desse grupo (Nuzillard et al., 1999). Além disso, parte das proteínas (20-30\%) não é de reserva, mas sim enzimática e estrutural (Sosulski \& Sosulski, 2006) e em leguminosas é muito comum a ocorrência de lectinas (proteínas que se ligam a carboidratos ou glicopeptídeos) e inibidores de enzimas digestivas (principalmente de tripsina e quimotripsina) (Sgarbieri, 1996). Inibidores de tripsina foram encontrados em Dimorphandra mollis (Macedo et al., 2000) e Inga laurina (Macedo et al., 2007).

\section{Potencial econômico}

A média de rendimento lipídico nas espécies analisadas foi muito baixa (Tabela 2), exceto em Acosmium subelegans, que apresentou valor comparável (13,14\%) ao de semente de lupino (10\%) (Sosulski \& Sosulski, 2006), farelo de arroz (8-15\%) e gérmem de trigo (7-12\%) (Pokorný, 2006). Sua composição de ácidos graxos tem potencial para indústria alimentícia, devido à alta proporção de ácidos insaturados $(66,6 \%)$, característica considerada ideal para óleos comestíveis, embora ela contenha teores substanciais de ácidos saturados (33,8\%), indesejáveis por elevar o risco de doenças cardiovasculares (Schaefer, 1997). Entretanto, cabe ressaltar que uma parte desses ácidos saturados não é de cadeia curta (C12:0 a C16:0), 14,5\% sendo representada pelo ácido esteárico, que é considerado neutro em relação a seu efeito nos lipídios do sangue (Kris-Etherton et al., 2005). No geral, sua composição não difere muito de outros óleos comumente utilizados na alimentação humana, como os de girassol, gergelim e milho (Pokorný, 2006). O óleo de Andira laurifolia se assemelharia ao óleo de amendoim (Pokorný, 2006), não fosse o alto teor de ácido palmítico (30\%), mas também possui um rendimento de óleo extremamente baixo $(0,54 \%)$. De fato, o alto teor de ácido palmítico na maioria 
das espécies de cerrado analisadas no presente trabalho e por Mayworm e Salatino (1996a) é um fator importante e indesejável para a utilização como fonte alimentícia.

A composição de ácidos graxos da semente de um indivíduo de Inga uraguensis, apresentou-se rica em ácidos saturados de cadeia longa e teria potencial para o uso na indústria de sabões (Mayworm, 1994), entretanto, o baixíssimo rendimento de óleo $(0,24 \%)$ inviabiliza seu aproveitamento econômico. Sabões também podem ser produzidos a partir de gorduras que possuem ácidos graxos de cadeia longa e altamente insaturadas, sendo suaves, mas com melhor detergência em água morna (Ahmad, 1994 apud Mayworm, 1994). Anadenanthera peregrina var. falcata e Acosmium subelegans, pelas suas maiores proporções de ácidos graxos insaturados, teriam bom potencial para produção desse tipo de sabão.

Para a produção de biodiesel, podem ser utilizados tanto óleos vegetais como gorduras animais (Ramadhas et al., 2004), até mesmo gorduras residuais, mas óleos com ácidos graxos saturados, de cadeia longa e não ramificados conferem melhores propriedades ao biodiesel (Knothe \& Dunn, 2005). Nesse contexto, a maior parte das espécies analisadas teria um bom potencial, devido à maior tendência a apresentarem ácidos saturados (em relação a espécies não de cerrado), não fosse o baixo rendimento geral.

Para a indústria de tintas, vernizes e revestimentos, é importante que os óleos sejam secantes, uma propriedade que depende da presença de ácidos graxos com duas ou mais insaturações, como o linoléico e linolênico, entre outros (Van De Mark \& Sandefur, 2005). Nenhuma das espécies analisadas possui mais de $50 \%$ desses ácidos, inviabilizando seus usos nessa área.

A maior parte das leguminosas utilizadas na alimentação apresenta 4-6\% de açúcares solúveis totais (Sosulski \& Sosulski, 2006; Martín-Cabrejas et al., 2008), podendo a soja apresentar $8 \%$. Dessa forma, as espécies com valores igualmente baixos e potencial de utilização são: Dimorphandra mollis, Copaifera langsdorfii, Andira laurifolia, Crotalaria flavicoma e Anadenanthera peregrina var. falcata. Panegassi e col. (2001) analisaram os polissacarídeos de parede de D.mollis e sugeriram a utilização da goma (83,2\% de galactomananos) de suas sementes em formulações de alimentos. Esses autores ressaltam que as favas dessa espécie já são utilizadas para extração de rutina e a utilização de suas sementes propiciaria um melhor aproveitamento da matéria-prima, uma vez que as sementes são descartadas. C.langsdorfii é amplamente conhecido e seu óleo é utilizado por suas 
propriedades farmacêuticas desde antes da chegada dos portugueses, pelos índios. Os estudos realizados com o gênero, em geral, são sobre a composição e propriedades farmacológicas do óleo e até agora poucos foram realizados acerca das suas sementes (Veiga Junior \& Pinto, 2002). Foram relatados $40 \%$ de xiloglucanos em C.langsdorfii (Franco et al., 1996), que por ser uma boa fonte de fibras poderia ser utilizado na alimentação. Entretanto, a presença de cumarina umbeliferona (Maia et al., 1978) prejudica o potencial de utilização nessa área, por ser tóxico (Vassallo et al., 2004).

A considerável variação genética no teor de oligossacarídeos nas sementes sugere que programas de melhoramento para produção de sementes com baixo teor desses açúcares seriam bem sucedidos (Cochrane, 2000). Nesse contexto enquadra-se Inga uraguensis. Essa espécie apresentou teor relativamente alto de amido (17,86\%), o mesmo ocorrendo com Andira laurifolia (56,27\%) (Tabela 3) e sugerindo possível utilização econômica, uma vez que o amido é a fonte básica de energia para grande parte da população mundial e um dos mais importantes materiais de uso industrial (Liu, 2005). Entretanto, para utilização industrial e alimentar, características morfológicas, de temperatura de gelatinização, e conteúdo de amilose são fundamentais (Amaral, 2005) e por isso, estudos mais detalhados acerca das características do amido são necessários.

As espécies com alto teor de proteínas (Crotalaria flavicoma, Acosmium subelegans e Anadenanthera peregrina var. falcata) seriam potencialmente interessantes, entretanto, para consumo, é necessário estudá-las com maior detalhe, em relação à composição de aminoácidos e principalmente quanto aos fatores antinutricionais e tóxicos. A característica comum a todas as proteínas de leguminosas é a baixa concentração de metionina e cisteína e a soma desses aminoácidos sulfurados está muito abaixo do necessário para se ter a melhor utilização das proteínas, sem modificar a concentração dos demais aminoácidos. Entretanto, a elevada concentração de lisina é considerada de grande valor na complementação das proteínas de cereais, que em geral são pobres em lisina (Sgarbieri, 1996). Outro fator importante na determinação do valor nutritivo da proteína é sua digestibilidade (Sgarbieri, 1996), que em leguminosas de grãos costuma ser de 65 a 88\% (Sosulski \& Sosulski, 2006). A digestibilidade pode ser reduzida por diversos compostos, como as substâncias fenólicas, inibidores de enzimas digestivas, entre outros fatores (Sgarbieri, 1996), embora tenha sido proposto que fatores estruturais intrínsecos da 
proteína sejam a maior causa da baixa digestibilidade de proteínas de sementes de leguminosas (Carbonaro et al., 1997). O tratamento pelo calor pode melhorar a digestibilidade por meio da inativação dos inibidores de protease e lectinas (VanEtten et al., 1967; Singh \& Singh, 1992), entretanto, Carbonaro e col. (1997) relataram que a baixa digestibilidade não foi completamente superada nem ao menos reduzida por meio do processo de aquecimento, possivelmente como conseqüência da agregação das proteínas. Convém ressaltar que o excesso de aquecimento reduz o valor nutritivo, principalmente devido aos danos sofridos pela metionina, o aminoácido essencial mais limitante das leguminosas (Shemer \& Perkins, 1975). Mais recentemente, Urbano e col. (2005) relataram a melhora na digestibilidade da proteína de Pisum sativum por meio de germinação e Shoshima e col. (2005) por meio da remoção do tegumento de Vigna unguiculata, onde se concentram taninos e fibras. Os fatores antinutricionais mais importantes que devem ser estudados nas sementes de leguminosas são lectinas, inibidores de protease, saponinas e taninos. As toxinas incluem alcalóides e aminoácidos não-protéicos (Sgarbieri, 1996; Bell, 2003; Sosulski \& Sosulski, 2006). Dessa forma, a seleção de sementes para alimentação humana e/ou animal requerem a extração ou remoção dessas substâncias deletérias se elas estiverem presentes em quantidade suficiente a ponto de serem danosos à saúde.

Cabe lembrar que a utilização econômica das espécies merece ainda uma análise acerca do impacto ambiental, pois o uso indiscriminado pode levar à extinção dessas espécies. Segundo Silva e col. (2001 apud Albuquerque, 2003), Dimorphandra mollis se encontra em risco de extinção e Veiga Junior e Pinto (2002) afirmam que árvores de Copaifera continuam sendo derrubadas, com sua extração não-racional.

\section{Implicações na germinação e desenvolvimento da plântula}

Segundo Albuquerque e col. (2003), as pesquisas que são realizadas com recursos genéticos de espécies nativas somente terão aplicação se for assegurada a sobrevivência e a disponibilidade desse material genético. Dentro desse contexto são necessárias pesquisas que avaliem a melhor forma de propagação, para que sejam estabelecidas técnicas de cultivo e manejo. Estudos sobre a germinação vêm 
sendo realizados com o intuito de fornecer informações sobre a qualidade das sementes, que podem ser usadas na seleção de lotes para armazenamento, comercialização e semeadura, além de formação de bancos de sementes. Para espécies de cerrado, antes de 1964 acreditava-se que a propagação vegetativa era a única responsável pela perpetuação das espécies (Albuquerque et al., 2003). Entretanto, hoje se conhece a viabilidade e a germinação de espécies nativas do cerrado em condições naturais. O conhecimento da composição da semente é um item relevante no que se refere à germinação de sementes e desenvolvimento de plântulas. No início da germinação, em sementes portadoras de amido predominam a reparação e ativação de mitocôndrias preexistentes, enquanto sementes que armazenam lipídios geralmente produzem novas mitocôndrias (Morohashi, 1986 apud Bewley, 1997). Os açúcares solúveis permitem a germinação, alimentando o metabolismo inicial (e.g., respiração) e a extensão dos tecidos do eixo embrionário e, quando presentes em grandes quantidades, elas também podem ajudar no desenvolvimento inicial das plântulas (Ziegler, 1995). Recentemente tem sido proposto que esses açúcares têm outra importante função, conferindo tolerância à dessecação e armazenabilidade às sementes. O aumento nos níveis de sacarose e particularmente dos oligossacarídeos da série rafinósica, têm sido correlacionadas com o início da tolerância à dessecação durante o desenvolvimento de sementes ortodoxas. A longevidade das sementes tem sido positivamente correlacionada com os teores desses açúcares (Steadman et al., 1996). Dentre os polissacarídeos de parede, os mananos conferem dureza e proteção mecânica ao embrião; os galactomananos e, possivelmente os xiloglucanos, têm funções no controle da embebição da água e xeroproteção, enquanto os galactanos seriam um importante elemento na modulação da expansão cotiledonar durante o desenvolvimento (Buckeridge et al., 2000c). Dessa forma, os resultados obtidos no presente trabalho podem contribuir para posteriores trabalhos em fisiologia da germinação de plantas do cerrado. 


\section{CONSIDERAÇÕES FINAIS}

Levando-se em conta o conjunto das amostras analisadas, algumas conclusões podem-se extrair quanto à composição de seus nutrientes orgânicos principais:

- A maioria das espécies apresenta nas sementes baixos teores de lipídios, com exceção de Acosmium subelegans, que apresentou rendimento de $13 \%$ e uma composição de ácidos graxos similar às de óleos comumente usados na alimentação.

- As sementes das espécies apresentaram teores consideráveis de açúcares solúveis totais (5-10\%). Os teores de amido são extremamente baixos, excetuandose apenas Andira laurifolia, com mais de $50 \%$, valor similar ao de grãos utilizados na alimentação humana.

- Quanto ao teor de proteínas, destacaram-se Crotalaria flavicoma, Acosmium subelegans e Anadenanthera peregrina var. falcata, com $25-30 \%$, embora esses valores possam estar superestimados devido à presença de compostos nitrogenados não-protéicos.

As análises realizadas neste trabalho constituem apenas o princípio do conhecimento para se sugerir a utilização econômica dessas espécies. É necessário avaliar, posteriormente, a composição de mono- e oligossacarídeos, principalmente de oligossacarídeos da série rafinósica; características morfológicas, de temperatura de gelatinização e conteúdo de amilose do amido; a quantificação e composição dos polissacarídeos de parede celular; os teores de vitaminas e minerais; e, principalmente, a composição de aminoácidos das proteínas. Além disso, é fundamental analisar a presença de diversos fatores anti-nutricionais e tóxicos, freqüentes em Leguminosae. 


\section{RESUMO}

O cerrado é o segundo maior bioma do país, ocupando em torno de 20 a $25 \%$ do território brasileiro, sendo detentor de grande diversidade vegetal. Entretanto, agressões a áreas de cerrado vêm ocorrendo em escala crescente, o que torna urgente estudos detalhados sobre espécies representativas do bioma. $\mathrm{O}$ objetivo deste trabalho foi o de analisar o conteúdo de nutrientes orgânicos das sementes de leguminosas, uma das famílias de maior riqueza no cerrado. Foram analisados lipídios, carboidratos e proteínas de oito espécies: Acosmium subelegans, Anadenanthera peregrina var. falcata, Andira laurifolia, Copaifera langsdorfii, Crotalaria flavicoma, Dimorphandra mollis, Hymenaea stigonocarpa e Inga uraguensis. Em geral, as amostras apresentaram baixos teores de lipídios (aproximadamente 5\%) e a composição de ácidos graxos mostrou predominância do ácido linoléico na maioria das espécies e também uma tendência a alta proporção de ácidos graxos saturados, principalmente ácido palmítico. A espécie com maior teor foi Acosmium subelegans (13\%), que apresentou valor comparável ao de semente de lupino e sua composição de ácidos graxos é similar aos de óleos de girassol, gergelim e milho. As espécies apresentaram teores consideráveis de açúcares solúveis totais (5-10\%). Os rendimentos de amido foram baixos (inferior a $1 \%$ ), com exceção de Inga uraguensis (17,86\%) e Andira laurifolia (56,27\%). Esta última apresentou valores similares aos de espécies comumente utilizadas na alimentação, como feijões, ervilha e lentilha. Foram obtidos teores de proteínas de 9 a $30 \%$ e as espécies com maiores valores foram Crotalaria flavicoma (25\%), Acosmium subelegans $(28,34 \%)$ e Anadenanthera peregrina var. falcata $(30,35 \%)$. Essas três espécies possuem teores semelhantes e até superiores aos de algumas leguminosas, como feijão comum, lentilha, ervilha e amendoim, embora seja inferior ao da soja. Entretanto, em Leguminosae é freqüente a presença de diversos fatores anti-nutricionais e tóxicos, que devem ser avaliados antes de se sugerir uma potencial utilização das sementes dessas espécies na alimentação humana e de animais. 


\section{ABSTRACT}

Cerrado (Brazilian savanna) is one of the largest biomes in the country, covering about 20 to $25 \%$ of the Brazilian territory and housing a wide biodiversity. However, Cerrado vegetation has undergone an increasing degree of aggression. Thus, detailed studies about Cerrado plant species are urgently needed. The aim of this work is to analyse organic nutrients of seeds of representative Cerrado species. Leguminosae is one of the predominant families of the Cerrado flora. Analysis of contents of lipids, carbohydrates, and proteins were carried out, involving eight species: Acosmium subelegans, Anadenanthera peregrina var. falcata, Andira laurifolia, Copaifera langsdorfii, Crotalaria flavicoma, Dimorphandra mollis, Hymenaea stigonocarpa e Inga uraguensis. Regarding most species, the seed samples analysed has low oil contents and the fatty acid compositions are characterized by the predominance of linoleic acid. A trend was observed toward high levels of saturated fatty acids, mainly palmitic acid. Acosmium subelegans showed the highest lipid content (13\%), comparable to lupin seeds, and its fatty acid composition was similar to sunflower, sesame and corn oils. All samples analysed contain relatively high amounts of total soluble sugar $(5-10 \%)$, which include oligosaccharides. Starch contents of most samples were low (below 1\%), except for Inga uraguensis (17,86\%) and Andira laurifolia (56,27\%). The latter value is similar to those reported for commom seed foods, such as beans, peas and lentils. Crude protein contents ranged from 9 to $30 \%$, the species with higher values being Crotalaria flavicoma (25\%), Acosmium subelegans (28,34\%) and Anadenanthera peregrina var. falcata $(30,35 \%)$. The protein content of seeds of these species are similar and even higher than those reported for commonly cultivated legumes, such as bean, lentil, pea and peanut, although lower than soybean content. Several antinutritional and toxic components are frequent in Leguminosae seeds, so that the presence of these substances has to be considered before any suggestion regarding utilization of these species in human and animal nutrition may be put forward. 


\section{REFERÊNCIAS}

ABBADI, A.; DOMERGUE, F.; MEYER, A.; RIEDEL, K.; SPERLING, P.; ZANK, T.K.; HEINZ, E. Transgenic oilseeds as sustainable source of nutritionally relevant $C 20$ and C22 polyunsaturated fatty acids? European Journal of Lipid Science and Technology, v.103, p.106-113, 2001.

ABELL, B.M.; HOLBROOK, L.A.; ABENES, M.; MURPHY, D.J.; HILLS, M.J.; MOLONEY, M.M. Role of the proline knot motif in oleosin endoplasmic reticulum topology and oil body targeting. Plant Cell, v.9, p.1481-93, 1997.

ACHINEWHU, S.C. The effect of fermentation on carbohydrate and fatty acid composition of African oil bean seed. Food Chemistry, v.19, p.105-116, 1986.

ADEWUSI, S.R.A.; FALADE, O.S.; HARWOOD, C. Chemical composition of Acacia colei and Acacia tumida seeds - potential food sources in the semi-arid tropics. Food Chemistry, v.80, p.187-195, 2003.

AITZETMÜLLER, K.; MATTHÄUS, B.; FRIEDRICH, H. A new database for seed oil fatty acids - the database SOFA. European Journal of Lipid Science and Technology, v.105, p.92-103, 2003.

AHMAD, M.U.; HUSAIN, S.K.; OSMAN, S.M. Ricinoleic acid in Phyllanthus niruri seed oil. Journal of the American Oil Chemists' Society, v.58, p.673-674, 1981.

AKOH, C.C.; CHANG, S.W.; LEE, G.C.; SHAW, J.F. Enzymatic approach to biodiesel production. Journal of Agricultural and Food Chemistry, v.55, p.8995-9005, 2007.

AKPINAR, N.; AKPINAR, M.A.; TÜRKOĞLU, Ş. Total lipid content and fatty acid composition of the seeds of some Vicia L. species. Food Chemistry, v.74, p.449-453, 2001.

ALBUQUERQUE, M.C.; COELHO, M.F.B.; ALBRECHT, J.M.F. Germinação de sementes de espécies medicinais do cerrado. In: COELHO, M.F.B.; COSTA JÚNIOR, P.; DOMBROSKI, J.L.D. (Orgs.), Etnobiologia, etnoecologia e plantas medicinais. Cuiabá-MT: Unicem Publicações, 2003. p.157-181. AL-KAISEY, M.T.; WILKIE, C.B. The polysaccharides of agricultural lupin seeds. 
Carbohydrate Research, v.227, p.147-161, 1992.

AMARAL, L.I.V. Metabolismo de carboidratos estruturais e de reserva em cotilédones de Hymenaea courbaril L.(Jatobá). 2005. 123p. Tese (Doutorado em Botânica) - Instituto de Biociências, Universidade de São Paulo, São Paulo, 2005.

AMARAL, L.I.V.; GASPAR, M.; COSTA, P.M.F.; AIDAR, M.P.M.; BUCKERIDGE, M.S. Novo método enzimático rápido e sensível de extração e dosagem de amido em materiais vegetais. Hoehnea, v.34, p.425-431, 2007.

ANGELO Z, D.; CAPRILES, J.M. La importancia de las plantas psicotrópicas para la economía de intercambio y relaciones de interacción en el altiplano sur andino. Chungará (Arica), v.36 supl., p.1023-1035, 2004.

AOAC. Official methods of analysis of Association of Official Analytical Chemists. Arlington: Association of Official Analytical Chemists, 1995.

ASHTON, F.M. Mobilization of Storage Proteins of Seeds. Annual Review of Plant Physiology, v.27, p.95-117, 1976.

ASILBEKOVA, D.T. Lipids of Thermopsis alterniflora bean seeds and shells. Chemistry of Natural Compounds, v.40, p.532-534, 2004.

ASILBEKOVA, D.T.; UL'CHENKO, N.T.; RAKHIMOVA, N.K.; NIGMATULLAEV, A.M.; GLUSHENKOVA, A.I. Seed lipids from Crotalaria alata and Guizotia abyssinica. Chemistry of Natural Compounds, v.41, p.596-597, 2005.

BAGCI, E.; BRUEHL, L.; ÖZÇELIK, H.; AITZETMÜLLER, K.; VURAL, M.; ŞAHIM, A. A study of the fatty acid and tocochromanol patterns of some Fabaceae (Leguminosae) plants from Turkey. Grasas y Aceites, v.55, p.378-384, 2004.

BAILEY, R.W. Polysaccharides in the Leguminosae. In: HARBORNE, J.B.; BOULTER, D.; TURNER, B.L. (Eds.) Chemotaxonomy of the Leguminosae. London: Academic Press, 1971. p.503-541.

BALL, S.G., WAL, M.H.B.J.; VISSER, R.G.F. Progress in understanding the biosynthesis of amylose. Trends in Plant Science, v.3, p.462-467, 1998.

BALOGUN, A.M.; FETUGA, B.L. Fatty acid composition of seed oils of some members of the Leguminosae family. Food Chemistry, v.17, p.175-182, 1985. 
BATALHA, M.A.; ARAGAKI, S.; MANTOVANI, W. Florística do cerrado de Emas (Pirassununga, SP). Boletim Botânico da Universidade de São Paulo, v.16, p.49-64, 1997.

BATALHA, M.A.; MANTOVANI, W. Floristic composition of the cerradão in the Pé-deGigante Reserve (Santa Rita do Passa Quatro, Southeastern Brazil). Acta Botanica Brasilica, v.15, p.289-304, 2001.

BELL, E.A. Nonprotein amino acids of plants: significance in medicine, nutrition, and agriculture. Journal of Agricultural and Food Chemistry, v.51, p.2854-2865, 2003.

BEWLEY, J.D. Seed germination and dormancy. The Plant Cell, v.9, p.1055-1066, 1997.

BEWLEY, J.D.; BLACK, M. Seeds : physiology of development and germination. $2^{\text {nd }}$ ed. New York: Plenum Press, 1994. 445p.

BINKOSKI, A.E; KRIS-ETHERTON, P.M.; WILSON, T.A.; MOUNTAIN, M.L.; NICOLOSI, R.J. Balance of unsaturated fatty acids is important to a cholesterollowering diet: comparison of mid-oleic sunflower oil and olive oil on cardiovascular disease risk factors. Journal of American Diet Association, v.105, p.1080-1086, 2005.

BOBBIO, F.O.; BOBBIO, P. Introdução à química de alimentos. $2^{\mathrm{a}}$ ed. São Paulo: Livraria Varela, 2003. 223p.

BOESEWINKEL, F. D.; BOUMAN, F. The seed: structure and function. In: KIGEL, J.; GALILI, G. (Eds). Seed development and germination. New York: Marcel Dekker, 1995. p.1-24.

BOUHNIK, Y.; RASKINE, L.; SIMONEAU, G.; VICAUT, E.; NEUT, C.; FLOURIE, B. The capacity of nondigestible carbohydrates to stimulate fecal bifidobacteria in healthy humans: A double-blind, randomized, placebo-controlled, parallelgroup, dose-response relation study. American Journal of Clinical Nutrition, v.80, p.1658-1664, 2004.

BRADLEY, W.B. Cereal grain as food. Cereal Science Today, v. 11, p.240-242, 1966.

BRILLOUET, J.M.; RIOCHET, D. Cell wall polysaccharides and lignin in cotyledons 
and hulls of seeds from various lupin (Lupinus L.) species. Journal of Science in Food Agriculture, v.34, p.861-868, 1983.

BROUN, P.; GETTNER, S.; SOMERVILLE, C. Genetic engineering of plant lipids. Annual Review of Nutrition, v19, p.197-216, 1999.

BRUNETON, J. Pharmacognosy, phytochemistry, medicinal plants. $2^{\mathrm{a}}$ ed. Andover, Intercept, 1999. 1119p.

BUCKERIDGE, M.S; CROMBIE, H.J.; MENDES, C.J.M.; REID, J.S.G.; GIDLEY, M.J.; VIEIRA, C.C.J. A new family of oligossacharides from the xyloglucan of Hymenaea courbaril L. (Leguminosae) cotyledons. Carbohydrate Research, v.303, p.233-237, 1997.

BUCKERIDGE, M.S.; DIETRICH, S.M.C. Galactomannan from Brazilian legume seeds. Revista Brasileira de Botânica, v.13, p.109-112, 1990.

BUCKERIDGE, M.S.; DIETRICH, S.M.C.; LIMA, D.U. Galactomannans as the reserve carbohydrate in legume seeds. In: GUPTA, A.K.; KAUR, N. (Eds.). Carbohydrate reserves in plants - synthesis and regulation. Amsterdam, Elsevier Science, 2000a. p.283-316.

BUCKERIDGE, M.S., PANEGASSI, V.R.; DIETRICH, S.M.C. Storage carbohydrate mobilisation in seeds of Dimorphandra mollis Benth. (Leguminosae) following germination. Revista Brasileira de Botânica, v.18, p. 171-175, 1995a.

BUCKERIDGE, M.S.; PANEGASSI, V.R.; ROCHA, D.C.; DIETRICH, S.M.C. Seed galactomannan in the classification and evolution of the Leguminosae.

Phytochemistry, v.38, p.871-875, 1995b.

BUCKERIDGE, M.S.; REID, J.S.G. Purification and properties of a novel $\beta$ galactosidase or exo- $\beta-(1,4)$-galactanase from the cotyledons of germinated Lupinus angustifolius L. seeds. Planta, v.192, p.502-511, 1994.

BUCKERIDGE, M.S.; REID, J.S.G. Major cell wall storage polysaccharides in legume seeds: structure, catabolism and biological functions. Ciência e Cultura, v.48, p.153-162, 1996.

BUCKERIDGE, M.S.; ROCHA, D.C.; REID, J.S.G.; DIETRICH, S.M.C. Xyloglucan structure and post-germinative metabolism in seeds of Copaifera langsdorffii from savanna and forest populations. Physiologia Plantarum, v.86, p.145-151, 
1992.

BUCKERIDGE, M.S.; SANTOS, H.P; TINÉ, M.A.S. Mobilization of storage cell wall polysaccharides in seeds. Plant Physiology and Biochemisty, v.38, p.141156, $2000 b$.

BUCKERIDGE, M.S.; TINÉ, M.A.S.; SANTOS, H.P.; LIMA, D.U. Polissacarídeos de reserva de parede celular em sementes. Estrutura, metabolismo, funções e aspectos ecológicos. Revista Brasileira de Fisiologia Vegetal, v.12, p.137$162,2000 \mathrm{c}$.

CARBONARO, M.; CAPPELLONI, M.; NICOLI, S.; LUCARINI, M.; CARNOVALE, E. Solubility-digestibility relationship of legume proteins. Journal of Agricultural and Food Chemistry, v.45, p.3387-3394, 1997.

CHUDZIKOWISKI, R.J. Guar gum and its applications. Journal of the Society of Cosmetic Chemistry, v.22, p.43-60, 1971.

COCHRANE, M.P. Seed Carbohydrates. In: BLACK, M.; BEWLEY, J.D. (Eds.). Seed technology and its biological basis. England: Sheffield, 2000. p.85-120.

COUTINHO, L.M. O bioma do cerrado. In: KLEIN, A.L. (Ed.). Eugen Warming e o cerrado brasileiro: um século depois. São Paulo: Editora UNESP, Imprensa Oficial do Estado, 2002.

CUI, S.W.; WANG, Q. Functional properties of carbohydrates: Polysaccharide gums. In: HUI, Y.H. (Ed.), Handbook of food science, technology and engineering. New York, CRC Press, 2006. v.1, p.4-7.

DAMUDE, H.G.; KINNEY, A. Engineering oilseeds to produce nutritional fatty acids. Physiologia Plantarum, v.132, p.1-10, 2008.

DEA, I.C.M.; MORRISON, A. Chemistry and interactions of seed galactomannan. Advances in carbohydrate chemistry and biochemistry, v.31, p.241-312, 1975.

DE ANGELIS, R.C. Importância de alimentos vegetais na proteção da saúde fisiologia da nutrição protetora e preventiva de enfermidades degenerativas. São Paulo: Atheneu, 2001. 295p.

DE MUCCIARELLI, S.I.L.; DE ARELLANO, M.A.L.; CID, A.A.; DELUQUEZ, N.A.G.; 
FERNANDEZ, S. Chemical composition and nutritive value of the protein of Amaranthus auitensis. Archives of Latinoamerican Nutrition, v.40, p.69-74, 1990.

DE SMET, P.A.G.M. A multidisciplinary overview of intoxicating snuff rituals in the western hemisphere. Journal of Ethnopharmacology, v.13, p.3-49, 1985.

DIETRICH, S.M.C.; FIGUEIREDO-RIBEIRO, R.C.L.; CHU, E.P.; BUCKERIDGE, M.S. O açúcar das plantas. Ciência Hoje, v. 39, p.42-48, 1988.

DUBOIS, M.; GILLES, K.A.; HAMILTON, J.K.; REBERS, P.A.; SMITH, F. Colorimetric method for determination of sugars and related substances. Analytical Chemistry, v.28, p.350-356, 1956.

DUDMAN, W.F.; MILLERD, A. Immunochemical bahaviour of legumin and vicilin from Vicia faba: survey of related proteins in Leguminosae subfamily Faboideae.

Biochemical Systematics and Ecology, v.3, p.25-33, 1975.

DURIGAN, G.; SIQUEIRA, M.F.; FRANCO, G.A.D.C. Threats to the Cerrado remnants of the state of São Paulo, Brazil. Scientia Agricola, v.64, p.355-363, 2007.

EARLE, F.R.; JONES, Q. Analyses of seed samples from 113 plant families. Economic Botany, v.16, p.221-250, 1962.

EGOUNLETY, M.; AWORH, O.C. Effect of soaking, dehulling, cooking and fermentation with Rhizopus oligosporus on the oligosaccharides, trypsin inhibitor, phytic acid and tannins of soybean (Glycine max Merr.), cowpea (Vigna unguiculata L. Walp) and groundbean (Macrotyloma geocarpa Harms). Journal of Food Engineering, v.56, p.249-254, 2003.

EGYDIO, A.P.M. Caracterização morfológica e química de diferentes morfotipos de acerola (Malpighia glabra), considerando variações sazonais. 2004. 75 p. Dissertação (Mestrado em Botânica), Instituto de Biociências, Universidade de São Paulo, São Paulo, 2004.

ESAU, K. Anatomia das plantas com sementes. São Paulo: Edgard Blucher, 1986. 293p. 
EUA. Code of Federal Regulations. Title 21, Volume 21, Part 101, Section 101.9Nutrition labeling of food, 2007. Disponível em: http://www.gpoaccess.gov/cfr/index.html. Acesso em: 17 jan.2008.

EZEAGU, I.E.; MAZIYA-DIXON, B.; TARAWALI, G. Seed characteristics and antinutrient composition of 12 Mucuna accessions from Nigeria. Tropical and Subtropical Agroecosystems, v.1, p.129-139, 2003.

EZEAGU, I.E.; PETZKE, J.K.; METGES, C.C.; AKINSOYINU, A.O.; OLOGHOBO, A.D. Seed protein contents and nitrogen-to-protein conversion factors for some uncultivated tropical plant seeds. Food Chemistry, v.78, p.105-109, 2002.

FAÇANHA, J.G.V., VARELA, V.P. Resultados preliminares de estudos sobre a conservação e composição bioquímica de sementes de copaíba (Copaifera multijuga Hayne) Leguminosae. Acta Amazonica, v.16/17, p.377-382, 1986/1987.

FERRI, M.G. Ecologia dos cerrados. In: FERRI, M.G. (Coord.). IV Simpósio sobre o cerrado. Belo Horizonte: Livraria Itatiaia, 1977. p.15-31.

FIGUEIREDO-RIBEIRO, R.C.L.; DIETRICH, S.M.C.; CARVALHO, M.A.M.; VIEIRA, C.C.J.; ISEJIMA, E.M.; DIAS-TAGLIACOZZO, G.M.; TERTULIANO, M.F. As múltiplas utilidades dos frutanos. Ciência Hoje, v.14, p.16-18, 1992.

FILARDI, F.L.R. Espécies lenhosas de Leguminosae na estação ambiental de Volta Grande, Minas Gerais, Brasil. 2005. 150f. Dissertação (Mestrado em Botânica), Centro de Ciências Biológicas e da Saúde, Universidade Federal de Viçosa, Viçosa, MG, 2005.

FRANCO, T.T.; RODRIGUES, N.R.; SERRA, G.E.; PANEGASSI, V.R.;

BUCKERIDGE, M.S. Characterization of storage cell wall polysaccharides from Brazilian legume seeds and the formation of aqueous two-phase systems. Journal of Chromatography B, v.680, p.255-261, 1996.

FREITAS, F.O. Uso de grãos de amido na identificação e análise de materiais arqueológicos vegetais. Boletim de Pesquisa e Desenvolvimento, Brasília: Embrapa Recursos Genéticos e Biotecnologia, v.23, 2002. 26p.

FRIAS, J.; VIDAL-VALVERDE, C.; SOTOMAYOR, C.; DIAZ-POLLAN, C.; URBANO, $\mathrm{G}$. Influence of processing on available carbohydrate content and antinutritional 
factors of chickpeas. European Food Research and Technology, v.210, p.340-345, 2000.

FRIEDMAN, M. Nutritional value of proteins from different food sources. A review. Journal of Agricultural and Food Chemistry, v.44, p.6-29, 1996.

FUNK, C.D. Prostaglandins and leukotrienes: advances in eicosanoids biology. Science, v.294, p.1871-1875, 2001.

GLICKSMANN, M. Utilization of natural polissacharide gums in the food industry. Advances in Food Research, v.11, p.109-200, 1962.

GRUNWALD, C.; ENDRESS, A.G. Oil, fatty acid and protein content of seed harvests from soybeans exposed to $\mathrm{O}_{3}$ and/or $\mathrm{SO}_{2}$. Botanical Gazette, v.149, p.283-288, 1988.

GUARIM NETO, G.; MORAIS, R. G. Medicinal plants resources in the Cerrado of Mato Grosso State, Brazil: a review. Acta Botanica Brasilica, v.17, p.561-584, 2003.

GUNSTONE, F.D. Fatty acid and lipid chemistry. London: Blackie, 1996.

GUNSTONE, F.D. Major sources of lipids. In: GUNSTONE, F.D.; PADLEY, F.B.

(EdS.), Lipid technologies and applications. New York: Marcel Dekker, 1997. p.19-50.

GUNSTONE, F.D. Production and trade of vegetable oils. In: (Ed.),

Vegetable oils in food technology: composition, properties and uses. Oxford: Blackwell, 2002. p.1-17.

HABBEN, J.E.; LARKINS, B.A. Improving protein quality in seeds. In: KIGEL, J.; GALILI, G. (Eds). Seed Development and Germination. New York: Marcel Dekker, 1995. p. 791-810.

HANDRO, W. A semente, a germinação e a plântula de Andira humilis Mart. Ex Benth. 1968. Tese (Doutorado em Ciências), Faculdade de Filosofia, Ciências e Letras, Universidade de São Paulo, São Paulo, 1968.

HARBORNE, J.B. Phytochemistry of the Leguminosae. In: BISBY, F.A.; BUCKINGHAM, J.; HARBORNE, J.B. (Eds.). Phytochemical dictionary of the Leguminosae. London: Chapman and Hall, 1994. 
HAYASHI, T. Xyloglucans in the primary cell wall. Annual Review of Plant

Physiology and Plant Molecular Biology, v.40, p.139-168, 1989.

HEISER JUNIOR, C.B. Sementes para civilização. São Paulo: Ed. Nacional, 1977. $253 p$.

HELDT, H. Plant biochemistry. $3^{\text {rd }}$ ed. San Diego: Elsevier, 2005.

HIRST, E.L.; JONES, J.K.N.; WALDER, W.O. Pectic substances. Part 7. The constitution of the galactan from Lupinus albus. Journal of Chemical Society, p.1225-1229, 1947.

HORBOWICZ, M.; OBENDORF, R.L.; MCKERSIE, B.D.; VIANDS, D.R. Soluble saccharides and cyclitols in alfafa (Medicago sativa L.) somatic embryos, leaflets, and mature seeds. Plant Science, v.109, p.191-198, 1995.

HOSAMANI, K.M. A minor source of vernolic, malvalic, and sterculic acids in Pithecollobium dulce (syn. Inga dulcis) seed oil. Journal of the American Oil Chemists' Society, v.72, p.489-492, 1995.

HOSAMANI, K.M.; PATIL, A.S.; PATTANASHETTAR, R.S. Acacia arabica varietiesTelia babul, Vediana and Cupressiformis seed oils: a moderate source of coronaric and cyclopropene fatty acids. Industrial Crops and Products, v.15, p.131-137, 2002.

HOSAMANI, K.M.; RAMESH, H.S. Unusual fatty acids from Crotalaria striata Syn. Crotalaria mucronata seed oil. Industrial Crops and Products, v.14, p.223$227,2001$.

HOSAMANI, K.M.; SATTIGERI, R.M. Analysis of Cassia marginata and Cassia corymbosa seed oils: An approach for the industrial utilization. Industrial Crops and Products, v.17, p.57-60, 2002.

HOSSAIN, M.A.; BECKER, K. Nutritive value and antinutritional factors in different varieties of Sesbania seeds and their morphological fractions. Food Chemistry, v.73, p.421-431, 2001.

IZYDORCZYK, M.; CUI, S.W.; WANG, Q. Polysaccharide gums: structures, functional properties, and applications. In: CUI, S.W. (Ed.). Food carbohydrates: chemistry, physical properties and applications. New York: 
CRC Press, 2005. p.263-307.

JAMES, T.N. The toxic oil syndrome. Clinical Cardiology, v.17, p.463-470,1994.

JONES, Q.; EARLE, F.R. Chemical analyses of seeds II: oil and protein content of 759 species. Economic Botany, v.20, p.127-155, 1966.

JUDD, W.S.; CAMPBELL, C.S.; KELLOGG, E.A.; STEVENS, P.F.; DONOGHUE, M.J. Plant Systematics: a phylogenetic approach. $2^{\text {nd }} E d$. Massachusetts: Sinauer Associates, 2002.

KAPLAN, M. A. C.; FIGUEIREDO, M. R.; GOTTLIEB, O. R. Chemical diversity of plants from Brazilian Cerrados. Anais da Academia Brasileira de Ciência, v.66, p.50-55, 1994. Suplemento 1-parte I.

KATIYAR, S.K.; BHATIA, A.K. Fatty acid composition of Cicer soongaricum Steph. seed oil. Journal of the Indian Chemical Society, v.63, p.447-448, 1986. Disponível em: <http://www.bagkf.de/cgi/sofa/lds.pl?TAB_ID=TYP5_11647>. Acesso em: 23 jan. 2008. Resultados obtidos via base de dados SOFA (Seed Oil Fatty Acids).

KHAN, K.G., JACOBSEN, I., EGGUM, B.O. Nutritive value of some improved varieties of legumes. Journal of Science and Food Agriculture, v.30, p.395400, 1979.

KINGHORN, A.D.; SMOLENSKI, S.J. Alkaloids of Papilionoideae. In: POLHILL, R.M.; RAVEN, P.H. (Eds.) Advances in Legume Systematics - Part 2. Kew: Royal Botanic Gardens, 1981. p.585-598.

KINNEY, A.J. Genetic modification of plant oils for food uses. In: SHETTY, K.; PALIYATH, G.; POMETTO, A.; LEVIN, R.E. Food biotechnology. New York: CRC Press, 2006. p.723-733.

KNOTHE, G.; DUNN, R.O. Biodiesel: an alternative diesel fuel from vegetable oils or animal fats. In: ERHAN, S.Z. (Ed.), Industrial uses of vegetable oils. Maryland, AOCS, 2005. p.42-89.

KORVER, O.; KATAN, M.B. The elimination of trans fats from spreads: how science helped to turn an industry around. Nutritional Review, v.64, p.275-279, 2006.

KRIS-ETHERTON, P.M.; GRIEL, A.E.; PSOTA, T.L.; GEBAUER, S.K.; ZHANG, J.; 
ETHERTON, T.D. Dietary stearic acid and risk of cardiovascular disease: intake, sources, digestion, and absorption. Lipids, v.40, p.1193-1200, 2005.

KRONKA, F.J.N.; NALON, M.A.; MATSUKUMA, C.K.; PAVÃO, M.; GUILLAUMON, J.R.; CAVALLI, A.C.; GIANNOTTI, E.; IWANE, M.S.S.; LIMA, L.M.P.R.; MONTES, J.; DEL CALI, I.H. \& HAACK, P.G. Áreas de domínio do cerrado no Estado de São Paulo. São Paulo. Secretaria de Estado do Meio Ambiente, Instituto Florestal. 1998.

KUO, T.M.; LOWELL, C.A.; SMITH, P.T. Changes in soluble carbohydrates and enzymic activities in maturing soybean seed tissues. Plant Science, v.125, p.111, 1997.

KUO, T.M.; VANMIDDLESWORTH, J.F.; WOLF, W.J. Content of raffinose oligosaccharides and sucrose in various plant seeds. Journal of Agricultural and Food Chemistry, v.36, p.32-36, 1988.

LAMARQUE, A.L.; FORTUNATO, R.H.; MAESTRI, D.M.; GUZMÁN, C.A. Seed components and taxonomy of some Acacia species. Biochemical Systematics and Ecology, v.28, p.53-60, 2000a.

LAMARQUE, A.L.; MAESTRI, D.M.; YGADLO, J.A.; GUZMÁN, C.A. Chemical evaluation of Geoffroea decorticans seeds as source of oil and protein. Grasas y Aceites, v.51, p.241-243, 2000b.

LANDS, W.E. Dietary fat and health: the evidence and the politics of prevention: careful use of dietary fats can improve life and prevent disease. Annals of the New York Academy of Sciences, v.1055, p.179-192, 2005.

LEHNINGER, A.L. Princípios de bioquímica. São Paulo: Sarvier, 1995.

LEWIS, G.; SCHRIRE, B.; MACKINDER, B.; LOCK, M. (Eds.) Legumes of the world. Kew: Royal Botanic Garden, 2005. 577p.

LEWIS, G.P.; SCHRIRE, B.D. Leguminosae or Fabaceae? In: KLITGAARD, B.B.; BRUNEAU, A. (Eds). Advances in legume systematic - Part 10. Kew: Royal Botanical Gardens, v.10, p.1-3, 2003.

LIENER, I.E., Implications of antinutritional components in soybean foods. Critical Reviews in Food Science and Nutrition, v.34, p.31-67, 1994. 
LIMA, D.U.; BUCKERIDGE, M.S. Interaction between cellulose and storage xyloglucans: the influence of the degree of galactosylation. Carbohydrate Polymers, v.46, p.157-163, 2001.

LIMA, D.U.; OLIVEIRA, R.C.; BUCKERIDGE, M.S. Seed storage hemicelluloses as wet-end additives in papermaking. Carbohydrate Polymers, v.52, p.367-373, 2003.

LIU, Q. Understanding starches and their role in foods. In: CUI, S.W. (Ed.). Food carbohydrates: chemistry, physical properties and applications. New York: CRC Press, 2005. p.309-355.

LOUIS, S.; DELOBEL, B.; GRESSENT, F.; DUPORT, G.; DIOL, O.; RAHIOUI, I.; CHARLES, H.; RAHBÉ, Y. Broad screening of the legume family for variability in seed insecticidal activities and for the occurrence of the A1b-like knottin peptide entomotoxins. Phytochemistry, v.68, p.521-535, 2007.

MACEDO, M.L.R.; GARCIA, V.A.; FREIRE, M.G.M.; RICHARDSON, M.

Characterization of a Kunitz trypsin inhibitor with a single disulfide bridge from seeds of Inga laurina (SW.) Willd. Phytochemistry, v.68, p.1104-1111, 2007.

MACEDO, M.L.R.; MATOS, D.G.G.; MACHADO, O.L.T.; MARANGONI, S.; NOVELLO, J.C. Trypsin inhibitor from Dimorphandra mollis seeds: purification and properties. Phytochemistry, v.54, p.553-558, 2000.

MACHADO, R.B.; RAMOS NETO, M.B.; PEREIRA, P.G.P.; CALDAS, E.F.; GONÇALVES, D.A.; SANTOS, N.S.; TABOR, K.; STEININGER, M. Estimativas de perda da área do cerrado brasileiro. Brasília: Conservação Internacional, 2004. Relatório técnico não publicado.

MACLEOD, A.M.; MCCORQUODALE, H. Water-soluble carbohydrates of seeds of the Gramineae. New Phytologist, v.57, p.168-182, 1958.

MAESTRI, D.M.; FORTUNATO, R.H.; GUZMÁN, C.A.; TORRES, M.M.; LAMARQUE, A.L. Seed compositional studies of some species of Papilionoideae (Leguminosae) native to Argentina. Journal of the Science of Food and Agriculture, v.82, p.248-251, 2002.

MAIA, J.G.S.; VAREJÃO, M.J.C.; WALTER FILHO, W.; MOURÃO, A.P.; CRAVEIRO, A.A.; ALENCAR, J.W. Estudo químico de óleos essenciais, oleaginosas e 
látices da Amazônia. I. Composição e oxidação do óleo de uma espécie de Copaifera. Acta Amazonica, v.8, p.705, 1978.

MANTOVANI, W. Composição e similaridade florística, fenologia e espectro biológico do cerrado da reserva biológica de Moji Guaçu, estado de São Paulo. 1983. 147 p. Dissertação (Mestrado em Ecologia), Instituto de Biologia, Unicamp, Campinas, 1983.

MARTÍN-CABREJAS, M.A.; DÍAZ, M.F.; AGUILERA, Y.; BENÍTEZ, V.; MOLLÁ, E.; ESTEBAN, R.M. Influence of germination on the soluble carbohydrates and dietary fibre fractions in non-conventional legumes. Food Chemistry, v.107, p.1045-1052, 2008.

MATUDA, T.G.; NETTO, F.M. Caracterização química parcial da semente de jatobádo-cerrado (Hymenaea stigonocarpa Mart.). Ciência e Tecnologia de Alimentos, v.25, p.353-357, 2005.

MAYER, A.M.; POLJAKOFF-MAYBER, A. The germination of seeds. Exeter: Pergamon, 1975. 270p.

MAYWORM, M.A.S. Ácidos graxos de sementes de plantas de cerrado. 1994.

127f. Dissertação (Mestrado em Botânica), Instituto de Biociências, Universidade de São Paulo, São Paulo, 1994.

MAYWORM, M.A.S. Carboidratos e proteínas de sementes e lipídios de Vochysiaceae. 1999. 171f. Tese (Doutorado em Botânica), Instituto de Biociências, Universidade de São Paulo, São Paulo, 1999.

MAYWORM, M.A.S.; SALATINO, A. Fatty acid composition of 'Cerrado' seed oils. Journal of the Science of Food and Agriculture, v.72, p.226-230, 1996a.

MAYWORM, M.A.S.; SALATINO, A. Teores de óleo e composição de ácidos graxos de sementes de Cereus jamacaru DC. (Cactaceae), Zizyphus joazeiro Mart. (Rhamnaceae) e Anadenanthera colubrina (Benth) Brenan var. cebil (Griseb.) von Altschul. (Mimosaceae). Sitientibus, v.15, p.201-209, 1996b.

MAYWORM, M.A.S.; SALATINO, A.; BUCKERIDGE, M.S. Chemical composition of seeds of Peltophorum dubium Vog., a legume tree from the Brazilian Caatinga vegetation with potential for sustainable use of biodiversity in semi-arid regions. Hoehnea, v.31, p.175-179, 2004. 
MAZZUCA, M.; BALZARETTI, V. Fatty acids, sterols and other steroids from seeds of Patagonian Prosopis species. Journal of the Science of Food and Agriculture, v.83, p.1072-1075, 2003.

MEARS, J.A.; MABRY, T.J. Alkaloids in the Leguminosae. In: HARBORNE, J.B.; BOULTER, D.; TURNER, B.L. (Eds.) Chemotaxonomy of the Leguminosae. London: Academic Press, 1971. p.73-178.

MENDONÇA, R.C.;FELFILI, J.M.; WALTER, B.M.T.; SILVA JÚNIOR, M.C.; REZENDE, A.V.; FILGUEIRAS, T.S.; NOGUEIRA, P.E. Flora vascular do bioma cerrado. In: SANO, M.; ALMEIDA, S.P. (Eds.), Cerrado: ambiente e flora. Planaltina: EMBRAPA-CPAC, 1998. p.287-556.

MILLERD, A. Biochemistry of Legume Seed Proteins. Annual Review of Plant Physiology, v.26, p.53-72, 1975.

MIQUEL, M.; BROWSE, J. Lipid biosynthesis in developing seeds. In: KIGEL, J.; GALILI, G. (Eds). Seed development and germination. New York: Marcel Dekker, 1995. p.169-193.

MORAES, M.G. Carboidratos solúveis em gramíneas do cerrado. 2001. 127p. Tese (Doutorado em Botânica), Instituto de Biociências, Universidade de São Paulo, São Paulo, 2001.

MORRIS, J.B.; KAYS, S.E. Total dietary fiber variability in a cross section of Crotalaria juncea genetic resources. Crop Science, v.45, p.1826-1829, 2005.

MOSSÉ, J. Nitrogen to protein conversion factor for ten cereals and six legumes or oilseeds. A reappraisal of its definition and determination. Variation according to species and to seed protein content. Journal of Agricultural and Food Chemistry, v.38, p.18-24, 1990.

MYERS, A.M.; MORELL, M.K.; JAMES, M.G.; BALL, S.G. Recent progress toward understanding biosynthesis of the amylopectin crystal. Plant Physiology, v.122, p.989-997, 2000a.

MYERS, N.; MITTERMEIER, R.A.; MITTERMEIER, C.G.; FONSECA, G.A.B.; KENT, J. Biodiversity hotspots for conservation priorities. Nature, v.403, p.853-858, 2000b.

NAPIER, J.A. The Production of Unusual Fatty Acids in Transgenic Plants. Annual 
Review of Plant Biology, v.58, p.295-319, 2007.

NAIVIKUL, O. \& D'APPOLONIA, B.L. Comparison of legume and wheat flour carbohydrates. I. Sugar analysis. Cereal Chemistry, v.55, p.913-918, 1978.

NAYLOR, R.L.; GOLDBURG, R.J.; PRIMAVERA, J.H.; KAUTSKY, N.; BEVERIDGE, M.C.M.; CLAY, J.; FOLKE, C.; LUBCHENCO, J.; MOONEY, H.; TROELL, M. Effect of aquaculture on world fish supplies. Nature, v.405, p.1017-1024, 2000.

NUZILLARD, J.M.; CONNOLY, J.D.; DELAUDE, C.; RICHARD, B.; ZÈCHESHANROT, M.; MEN-OLIVIER, L.L. Computer-assisted structural elucidation. Alkaloids with a novel diaza-adamantane skeleton from the seeds of Acosmium panamense (Fabaceae). Tetrahedron, v.55, p.11511-11518, 1999.

OHLROGGE, J.B.; POLLARD, M.R.; STUMPF, P.K. Studies on biosynthesis of waxes by developing jojoba seed tissue. Lipids, v.13, p.203-10, 1977.

OLIVEIRA, E.; DUARTE, L.M.G. Gestão da biodiversidade e produção agrícola: o cerrado goiano. Cadernos de Ciência \& Tecnologia, v.21, p.105-142, 2004.

PANDEY, V.N.; SRIVASTAVA, A.K. Seed protein yield from some Crotalaria spp and in vitro nutritional quality of that from C.juncea. Plant Foods for Human Nutrition, v.40, p.195-200, 1990.

PANEGASSI, V.R.; SERRA, G.E.; BUCKERIDGE, M.S. Potencial tecnológico do galactomanano de sementes de faveiro (Dimorphandra mollis) para uso na indústria de alimentos. Revista Brasileira de Ciência e Tecnologia de Alimentos, v.20, p.406-415, 2001.

PENNINGTON, R.T.; LEWIS, G.; MARSH, M. Andira inermis subsp. inermis. Leguminosae-Papilionoideae. Curtis's Botanical Magazine, v.17, p.188-194, 2000.

PINTO, A.C.; GUARIEIRO, L.L.N.; REZENDE, M.J.C.; RIBEIRO, N.M.; TORRES, E.A.; LOPES, W.A.; PEREIRA, P.A. de P; DE ANDRADE, J.B. Biodiesel: an overview. Journal of the Brazilian Chemical Society, v.16, p.1313-1330, 2005.

POKORNÝ, J. Fats and oils: Science and applications. In: HUI, Y.H. (Ed.), Handbook of food science, technology and engineering. New York, CRC Press, 2006. v.1, p.34-6 34-10. 
POLHILL, R.M. Classification of the Leguminosae \& complete synopsis of legume genera. In: BISBY, F.A.; BUCKINGHAM, J.; HARBORNE, J.B. (Eds.), Phytochemical dictionary of the Leguminosae. London: Chapman \& Hall, 1994. p.xxxv-Ivii.

POLHILL, R.M.; RAVEN, P.H.; STIRTON, C.H. Evolution and systematics of the Leguminosae. In: POLHILL, R.M.; RAVEN, P.H. (Eds.), Advances in legume systematic - Part 1. Kew: Royal Botanic Gardens, 1981. p.1-26.

RAMADHAS, A.S.; JAYARAJ, S.; MURALEEDHARAN, C. Use of vegetable oils as I.C. engine fuels - A review. Renewable Energy, v.29, p.727-742, 2004.

RAO, P.U.; BELAVADY, B. Oligosaccharides in pulses: varietal differences and effects of cooking and germination. Journal of Agricultural and Food Chemistry, v.26, p.316-319, 1978.

RATTER, J.A.; BRIDGEWATER, S.; RIBEIRO, J.F. Analysis of the floristic composition of the Brazilian Cerrado vegetation iii: Comparison of the woody vegetation of 376 areas. Edinburgh Journal of Botany, v.60, p.57-109, 2003.

REDDY, N.R.; PIERSON, M.D.; SATHE, S.K.; SALUNKHE, D.K. Chemical, nutritional and physiological aspects of dry bean carbohydrates - A review. Food Chemistry, v.13, p.25-68, 1984.

REID, J.S.G.; EDWARDS, M.E. Galactomannans and other cell wall storage polysaccharides in seeds. In: STEPHEN, A.M. (Ed.), Food polysaccharides and their applications. New York, Marcel Dekker, 1995. p.155-186.

SAIKIA, P.; SARKAR, C.R.; BORUA, I. Chemical composition, antinutritional factors and effect of cooking on nutritional quality of rice bean [Vigna umbellata (Thunb; Ohwi and Ohashi)]. Food Chemistry, v.67, p.347-352, 1999.

SALO-VÄÄNÄNEM, P.P.; KOIVISTOINEN, P.E. Determination of protein in foods: comparison of net protein and crude protein $(\mathrm{N} \times 6,25)$ values. Food Chemistry, v.57, p.27-31, 1996.

SÁNCHEZ-MATA, M.C.; PEÑUELA-TERUEL, M.J.; CÁMARA-HURTADO, M.; DÍEZMARQUÉS, C.; TORIJA-ISASA, M.E. Determination of Mono-, Di-, and Oligosaccharides in Legumes by High-Performance Liquid Chromatography 
Using an Amino-Bonded Silica Column. Journal of Agricultural and Food Chemistry, v.46, p.3648-3652, 1998.

SÃO PAULO. Cerrado: bases para a conservação e uso sustentável das áreas de cerrado do Estado de São Paulo. São Paulo, Secretaria do Meio Ambiente, 1997. Série Probio.

SATHE, S.K.; DESHPANDE, S.S.; SALUNKHE, D.K. Dry beans of Phaseolus. A review. Part 2. Chemical composition: carbohydrates, fiber, minerals, vitamins, and lipids. CRC Critical Reviews in Food Science and Nutrition, v.21, p.4193, 1984.

SAXENA, V.K.; MISHRA, L.N. Analysis of the oil from the seeds of Sesbania aegyptiaca Poir. (Abstract). Asian Journal of Chemistry, v.15, p.1811-1813, 2003.

SCHAEFER, E.J. Effects of dietary fatty acids on lipoproteins and cardiovascular disease risk: summary. American Journal of Clinical Nutrition, v.65, p.1655S-1656S, 1997.

SCHERBUKHIN, V.D.; ANULOV, O.V. Legume seed galactomannans. Applied Biochemistry and Microbiology, v.35, p.229-244, 1999.

SCHULTES, R.E. The botanical and chemical distribution of hallucinogens. Annual Review of Plant Physiology, v.21, p.571-598, 1970.

SENGUPTA, A.; BASU, S. Triglyceride composition of Entada phaseolides seed oil. Journal of the Science of Food and Agriculture, v.29, p.677-682, 1978.

SGARBIERI, V.C. Estudo do conteúdo e de algumas características das proteínas e sementes de plantas da família Leguminosae. Ciência e Cultura, v.32, p.7884, 1980.

SGARBIERI, V.C. Proteínas em alimentos protéicos: propriedades, degradações, modificações. São Paulo: Varela, 1996.

SHEMER, M.; PERKINS, E.G. Degradation of methionine in heated soybean protein and the formation of Beta-methyl mercaptopropiomaldehyde. Journal of Agricultural and Food Chemistry, v.23, p.201-205, 1975.

SHEWRY, P.R. Seed Proteins. In: BLACK, M.; BEWLEY, J.D. (Eds.). Seed 
technology and its biological basis. England: Sheffield, 2000. p.42-84.

SHEWRY, P.R.; LUCAS, J.A. Plant proteins that confer resistance to pests and pathogens. Advances in Botanical Research, v.26, p.135-192, 1997.

SHIRAKAWA, M.; YAMTOYA, K.; NISHINARI, K. Tailoring of xyloglucan properties using an enzyme. Food Hydrocolloids, v.12, p.25-28, 1998.

SHOSHIMA, A.H.R.; TAVANO, O.L.; NEVES, V.A. Digestibilidade das proteínas do caupi (L. Walp) var. "Br-14 Mulato": efeito dos fatores antinutricionais. Brazilian Journal of Food Technology, v.8, p.299-304, 2005.

SHRESTHA, M.K.; PERI, I.; SMIRNOFF, P.; IRK, Y.; GOLAN-GOLDHIRSH, A. Jojoba seed meal proteins associated with proteolytic and protease inhibitory activities. Journal of Agricultural and Food Chemistry, v.50, p.5670-5675, 2002.

SILVERSTEIN, R.M.; WEBSTER, F.X. Identificação espectrométrica de compostos orgânicos. 6a ed. Rio de Janeiro: LTC, 2000. p.2-36.

SIMPSON, B.B.; OGORZALY, M.C. Economic botany: plants in our world. 3rd ed. New York: McGraw-Hill, 2001.

SINGH, U.; SINGH, B. Tropical grain legumes as important human foods. Economic Botany, v.46, p.310-321, 1992.

SIVAK, M. N.; PREISS, J. Starch synthesis in seeds. In: KIGEL, J.; GALILI, G. (Eds). Seed development and germination. New York: Marcel Dekker, 1995. p.139168.

SOMERVILLE, C.; BROWSE, J.; JAWORSKI, J. G.; OHLROGGE, J. B. Lipids. In: BUCHANAN, B; GRUISSEM, W.; JONES, R. (Eds). Biochemistry \& molecular biology of plants. Rockville: American Society of Plant Physiologists, 2000. p.456-527.

SOSULSKI, F.W.; ELKOWICZ, L.; REICHERT, R.D. Oligosaccharides in eleven legumes and their air-classified protein and starch fractions. Journal of Food Science, v.47, p.498-502, 1982. 
SOSULSKI, F.W.; IMAFIDON, G.I. Amino acid composition and nitrogen-to-protein conversion factors for animal and plant foods. Journal of Agricultural and Food Chemistry, v.38, p.1351-1356, 1990.

SOSULSKI, F.W.; SOSULSKI, K. Legumes: horticulture, properties and processing.

In: HUI, Y.H. (Ed.), Handbook of food sience, technology and engineering. New York, CRC Press, 2006. v.1, p.18-1 18-2.

SRIVASTAVA, M.; KAPOOR, V.P. Seed galactomannans: An overview. Chemistry \& Biodiversity, v.2, p.295-317, 2005.

STEADMAN, K.J.; PRITCHARD, H.W.; DEY, P.M. Tissue-specific Soluble Sugars in Seeds as Indicators of Storage Category. Annals of Botany, v.77, p.667-674, 1996.

TANNUS, J.L.S.; ASSIS, M.A. Composição de espécies vasculares de campo sujo e campo úmido em área de cerrado, Itirapina-SP, Brasil. Revista Brasileira de Botânica, v.27, p.489-506, 2004.

TOGASHI, M.; SGARBIERI, V.C. Caracterização química parcial do fruto do barú (Dypterix alata, Vog). Ciência e Tecnologia de Alimentos, v.14, p.85-95, 1994.

TOOKEY, H.L.; JONES, Q. New Sources of Water-Soluble Seed Gums. Economic Botany, v.19, p.165-174, 1965.

TOOKEY, H.L.; LOHMAR, R.L.; WOLFF, I.A.; JONES, Q. New sources of seed mucilages.Journal of Agricultural and Food Chemistry, v.10, p.131-133, 1962.

URBANO, G.; ARANDA, P.; VÍlCHEZ, A.; ARANDA, C.; CABRERA, L.; PORRES, J.M.; LÓPEZ-JURADO, M. Effects of germination on the composition and nutritive value of proteins in Pisum sativum, L. Food Chemistry, v.93, p.671679, 2005.

VAN DE MARK, M.R.; SANDEFUR, K. Vegetable oils in paint and coatings. In: ERHAN, S.Z. (Ed.), Industrial uses of vegetable oils. Maryland, AOCS, 2005. p.143-162.

VANETTEN, C.H.; KWOLEK, C.H.; PETERS, J.E.; BARCLAY, A.S. Plant seeds as protein sources for food or feed. Evaluation based on amino acid composition of 
379 species. Journal of Agricultural and Food Chemistry, v.15, p.10771089, 1967.

VASSALLO, J.D.; HICKS, S.M.; DASTON, G.P.; LEHMAN-MCKEEMAN, L.D.

Metabolic detoxification determines species differences in coumarin-induced hepatotoxicity. Toxicological Sciences, v.80, p.249-257, 2004.

VEIGA JUNIOR, V.F.; ANDADE JUNIOR, M.A.; FERRAZ, I.D.K.; CHRISTO, H.B.; PINTO, A.C. Constituintes das sementes de Copaifera officinalis L. Acta Amazonica, v.37, p.123-126, 2007.

VEIGA JUNIOR, V.F.; PINTO, A.C. O gênero Copaifera L. Química Nova, v.25, p.273-286, 2002.

VERBEKEN, D.; DIERCKX, S.; DEWETTINCK, K. Exudate gums: occurrence, production, and applications. Applied Microbiology and Biotechnology, v.63, p.10-21, 2003.

VICKERY, H.B. The protein of plants. Physiological Reviews, v.25, p.347-376, 1945.

VIDAL-VALVERDE, C.; FRIAS, J.; VALVERDE, S. Changes in the carbohydrate composition of legumes after soaking and cooking. Journal of American Diet Association, v.93, p.547-550, 1993.

VIDAL-VALVERDE, M.; SIERRA, I.; FRIAS, J.; PRODANOV, M.; SOTOMAYOR, C.; HEDLEY, C.L.; URBANO, G. Nutritional evaluation of lentil flours obtained after short-time soaking processes. European Food Research and Technology, v.15, p.138-144, 2002.

VITALE, A.; BOLLINI, R. Legume storage proteins. In: KIGEL, J.; GALILI, G. (Eds). Seed development and germination. New York: Marcel Dekker, 1995. p-73102.

VOGEL, A.J. Análises de química orgânica qualitativa. São Paulo, EPU, p.10201023, 1971.

WANG, T. Soybean oil. In: GUNSTONE, F.D. (Ed.), Vegetable oils in food technology: composition, properties and uses. Oxford: Blackwell, 2002. p.18-23. 
WANG, Q.; ELLIS, P.R.; ROSS-MURPHY, S.B.; REID, J.S.G. A new polysaccharide from a traditional Nigerian plant food, Detarium senegalense Gmelin. Carbohydrate Research, v.284, p.229-239, 1996.

WINK, M.; MOHAMED, G.I.A. Evolution of chemical defense traits in the Leguminosae: mapping of distribution patterns of secondary metabolites on a molecular phylogeny inferred from nucleotide sequences of the $r b c L$ gene. Biochemical Systematics and Ecology, v.31, p.897-917, 2003.

WOJCIECHOWSKI, M.F.; LAVIN, M.; SANDERSON, M.J. A phylogeny of legumes (Leguminosae) based on analysis of the plastid matK gene resolves many wellsupported subclades within the family. American Journal of Botany, v.91, n.11, p.1845-1861, 2004.

WOLFF, I.A.; KWOLEK, W.F. Lipids of the Leguminosae. In: HARBORNE, J.B.; BOULTER, D.; TURNER, B.L. (Eds.) Chemotaxonomy of the Leguminosae. London: Academic Press, 1971. p.231-255.

WYK, B.E. The value of chemosystematics in clarifying relationships in the genistoid tribes of papilionoid legumes. Biochemical Systematics and Ecology, v.31, p.875-884, 2003.

ZIEGLER, P. Carbohydrate degradation during germination. In: KIGEL, J.; GALILI, G. (Eds). Seed development and germination. New York: Marcel Dekker, 1995. p.447-474. 